\title{
Secular changes in sedimentation systems and sequence
}

\section{stratigraphy}

\author{
Patrick G. Eriksson ${ }^{1^{*}}$, Santanu Banerjee ${ }^{2}$, Octavian Catuneanu ${ }^{3}$, Patricia L. \\ Corcoran $^{4}$, Kenneth A. Eriksson ${ }^{5}$, Eric E. Hiatt ${ }^{6}$, Marc Laflamme ${ }^{7}$, Nils Lenhardt ${ }^{1}$, \\ Darrel G.F. Long ${ }^{8}$, Andrew D. Miall', Michael V. Mints ${ }^{10}$, Peir K. Pufahl ${ }^{11}$, Subir \\ Sarkar $^{12}$, Edward L. Simpson ${ }^{13}$, George E. Williams ${ }^{14}$ \\ $1^{1^{*}}$ Department of Geology, University of Pretoria, Pretoria 0002, South Africa; corresponding author; e- \\ mail: pat eriksson@up.ac.za \\ ${ }^{2}$ Department of Earth Sciences, IIT Bombay, Pawai, Mumbai 400 076, India \\ ${ }^{3}$ Department of Earth and Atmospheric Sciences, 1-26 Earth Sciences Building, University of Alberta, \\ Edmonton, Alberta T6G 2E3, Canada \\ ${ }^{4}$ Department of Earth Sciences, University of Western Ontario, London, Ontario N6A 5B7, Canada \\ ${ }^{5}$ Department of Geological Sciences, Virginia Tech., Blacksburg, VA 24061, USA \\ ${ }^{6}$ Geology Department, University of Wisconsin, Oshkosh, Oshkosh, Wisconsin, 54901-8649, USA \\ ${ }^{7}$ Department of Paleobiology, Smithsonian Institution, Washington DC, 20013-7012, USA; current \\ address: Department of Chemical and Physical Sciences, University of Toronto at Mississauga, \\ Mississauga, Ontario, L5L 1C6, Canada \\ ${ }^{8}$ Department of Earth Sciences, Laurentian University, Sudbury, Ontario P3E 2C6, Canada \\ ${ }^{9}$ Department of Geology, University of Toronto, 22 Russell Street, Toronto, Ontario M5S 3B1, Canada \\ ${ }^{10}$ Laboratory of the Early Precambrian Tectonics, Geological Institute of the Russian Academy of Sciences, \\ Pyzhevsky Street 7, 109017 Moscow, Russia \\ ${ }^{11}$ Department of Earth and Environmental Science, Acadia University, Wolfville, Nova Scotia, B4P 2R6, \\ Canada \\ ${ }^{12}$ Department of Geological Sciences, Jadavpur University, Kolkata 700 032, India \\ ${ }^{13}$ Department of Physical Sciences, Kutztown University of Pennsylvania, Kutztown, PA 19530, USA \\ ${ }^{14}$ Geology and Geophysics, University of Adelaide, Adelaide, SA 5005, Australia
}




\section{ABSTRACT}

The ephemeral nature of most sedimentation processes and the fragmentary character of the sedimentary record are of first-order importance. Despite a basic uniformity of external controls on sedimentation resulting in markedly similar lithologies, facies, facies associations and depositional elements within the rock record across time, there are a number of secular changes, particularly in rates and intensities of processes that resulted in contrasts between preserved Precambrian and Phanerozoic successions. Secular change encompassed (1) variations in mantle heat, rates of plate drift and of continental crustal growth, the gravitational effects of the Moon, and in rates of weathering, erosion, transport, deposition and diagenesis; (2) a decreasing planetary rotation rate over time; (3) no vegetation in the Precambrian, but prolific microbial mats, with the opposite pertaining to the Phanerozoic; (4) the long-term evolution of the hydrosphere-atmosphere-biosphere system. A relatively abrupt and sharp turning point was reached in the Neoarchaean, with spikes in mantle plume flux and tectonothermal activity and possibly concomitant onset of the supercontinent cycle. Substantial and irreversible change occurred subsequently in the Palaeoproterozoic, whereby the dramatic change from reducing to oxidising volcanic gases ushered in change to an oxic environment, to be followed at ca. 2.4-2.3 Ga by the "Great Oxidation Event" (GOE); rise in atmospheric oxygen was accompanied by expansion of oxygenic photosynthesis in the cyanobacteria. A possible global tectono-thermal "slowdown" from ca. 2.45-2.2 Ga may have separated a preceding plate regime which interacted with a higher energy mantle from a ca. 2.2-2.0 Ga Phanerozoicstyle plate tectonic regime; the "slowdown" period also encompassed the first known global-scale glaciation and overlapped with the GOE. While large palaeodeserts emerged from ca. $2.0-1.8 \mathrm{Ga}$, possibly associated with the evolution of the supercontinent cycle, widespread euxinia by ca. $1.85 \mathrm{Ga}$ ushered in the "boring billion" year period. A second time of significant and irreversible change, in the Neoproterozoic, saw a second major oxidation event and several low palaeolatitude Cryogenian (740-630 Ma) glaciations. With the veracity of the "Snowball Earth" model for Neoproterozoic glaciation being 
under dispute, genesis of Pre-Ediacaran low-palaeolatitude glaciation remains enigmatic. Ediacaran (635$542 \mathrm{Ma})$ glaciation with a wide palaeolatitudinal range contrasts with the circum-polar nature of Phanerozoic glaciation. The observed change from low latitude to circum-polar glaciation parallels advent and diversification of the Metazoa and the Neoproterozoic oxygenation (ca. $580 \mathrm{Ma}$ ), and was succeeded by the Ediacaran-Cambrian transition which ushered in biomineralization, with all its implications for the chemical sedimentary record.

Keywords: Fragmentary Sedimentary Record; Actualism; Secular Change in Rates and Intensities of Processes; Earth Mechanics; Palaeoatmospheric Evolution; Great Oxidation Events; Global Magmatic Slowdown; Glacial Events; Biological Evolution; Sequence Stratigraphy

\section{Contents}

1. Introduction

2. The nature of the sedimentary record and sequence stratigraphy

3. External (allogenic) controls at planetary or larger scale

3.1. Solar system mechanics and the Earth's rotation rate

3.2. Change from mantle-domination to plate-domination in the Earth's geodynamics

4. Internal (autogenic) sedimentary controls on the planetary scale

4.1. Introduction

4.2. Volcanic outgassing and volcanic record

4.3. Secular changes in carbonate sedimentation 
4.4. Biologic evolution and chemical sedimentation

5. Greenstone belt sedimentation

6. Earliest cratonic sedimentation

7. Alluvial sedimentation and secular change

8. Aeolian sedimentation and secular change

9. Glacigenic sedimentation and secular change

9.1. Archaean and Palaeoproterozoic glaciations

9.2. Neoproterozoic glaciations

9.3. Phanerozoic glaciations

9.4. Controls and secular changes

10. Littoral-shelf (epeiric) sedimentation and secular change

11. Discussion

11.1. Secular change, sequence stratigraphy and actualism

11.2. Significant and irreversible change in the nature of the Earth system: Neoarchaean

11.3. Significant and irreversible change in the nature of the Earth system: Palaeoproterozoic

\subsection{The "Boring Billion"?}

11.5. Significant and irreversible change in the nature of the Earth system: Neoproterozoic and beyond (Phanerozoic)

\section{Conclusions}

Acknowledgements

References 


\section{Introduction}

The Precambrian sedimentary record, in contrast to the Phanerozoic, while much longer also offers much greater challenges in studying secular change, not the least being the reality that error margins of at least ca. $1 \mathrm{Myr}$ in radiometric dating techniques effectively negate any possible time control for sequence stratigraphy at a chronological resolution of $<10^{0}-10^{1} \mathrm{Myr}$ (Catuneanu, 2006). Almost all rock types and sedimentary facies identified in the Precambrian record have Phanerozoic-Modern counterparts, with the significant exception of iron formations. The interplay between "first-order" controls of interacting mantle thermal and plate tectonic influences and "second-order" interaction of oceanic-atmospheric-biological influences (both in themselves subject to secular change) on the sedimentary record apply equally to basins of all antiquities (e.g., Eriksson et al., 2001, 2007; Bose et al., 2012). Few would challenge the dictum that it is the tectonic settings with their implicit effects on eustasy, topography, climate, denudation rates and basin formation that are the principal primary influence on global sedimentation patterns.

While a rather uniform chronological framework of changing first-order elements is often perceived (e.g., supercontinentality, global glaciations, whether of "SnowballEarth" affinity, cf. Kirschvink, 1992, or not), it is possible that diachroneity of influences and products was a more likely scenario (e.g., Eriksson et al., 2011b). Some unique events may also have intervened in the Earth's secular history, such as the possible “magmatic slowdown" (ca. 2.45-2.2 Ga) espoused by Condie et al. (2009a). 
Non-uniformitarian influences on sedimentation patterns include decreasing Earthrotation rates over time (e.g., Williams, 2000, 2004), concomitant changes in the Earth's climatic and thermal zonation (e.g., Rautenbach, 2001), and the influence of microbial mats on sediment stacking patterns and even sequence architecture (Sarkar et al., 2005; Catuneanu, 2006). This paper will attempt a succinct analysis of the complex array of fixed and changeable influences on global sedimentation patterns and their secular variation.

\section{The nature of the sedimentary record and sequence stratigraphy}

It has long been understood that the stratigraphic record is fragmentary (cf., Blackwelder's [1909] unconformity bounded successions of North America, see also Levorsen (1943) and Sloss's [1963] "sequences"). Barrell (1917) in a paper that was many years ahead of its time, was the first to clearly understand (1) the importance of what we now term accommodation, the space available for sediments to accumulate, and (2) the very episodic way in which accommodation is created and removed by geological processes. He demonstrated that under typical conditions of base-level rise and fall only a fraction of geological time may actually be represented by accumulated sediment. This was emphasized by Ager (1973) who remarked that "the stratigraphic record is more gap than record", and in a later study of major unconformities at the Grand Canyon, he stressed that every bedding plane "is, in effect, an unconformity" and that it "was during the breaks that most events probably occurred" (Ager, 1993, p. 14). 
The description and interpretation of bedding planes and bounding surfaces has become part of the standard practice of facies analysis. These surfaces constitute a hierarchy of importance reflecting their duration and extent, and there have been several attempts to develop hierarchical classifications of these surfaces and the units they enclose (e.g., van Wagoner et al., 1990; Nio and Yang, 1991; Miall, 1996). At the larger scale, Vail et al. (1977) erected a hierarchical classification for stratigraphic sequences.

Sequence stratigraphy has become the standard framework for the description and interpretation of the stratigraphic record at the regional scale (Catuneanu, 2006; Miall, 2010), and one of the central elements of sequence geology is the cyclicity of the stratigraphic record. Sequences are generated by a range of causative mechanisms operating over time scales ranging from $10^{4}$ to $10^{8}$ years (Table 1 ).

An important, yet neglected discovery about the nature of the sedimentary record is the correlation between the duration of a sedimentary unit and its sedimentation rate (Sadler, 1981; Fig. 1). With sedimentation rates ranging over more than eleven orders of magnitude, it is implied that, at every scale, from the individual bedset to the scale of a basin-fill, the time that can be accounted for by the accumulation of a given thickness of sediment, when measured at the appropriate time scale, accounts for a very small fraction of the total of elapsed time. To extend Ager's famous thought: there are gaps within the gaps, and the record is permeated with them, at every scale. Bailey and Smith (2010, p. 57-58) pointed out the ephemeral nature of most sedimentary processes: “...stratigraphic records are better viewed as the outcome of temporary cessation of the erosion and redistribution of sediment: 'frozen accidents' of accumulation." 
It is now widely recognised that not only the durations of stratigraphic gaps, but also the distribution of layer thicknesses and sedimentation rates in stratigraphic successions are fractal in nature (Plotnick, 1986; Schlager, 2004; Bailey and Smith, 2005). The fractal model provides an elegant basis for integrating our knowledge of the processes of accommodation generation with the data on varying sedimentation rates and the varying scales of hiatuses and the processes that operate over these various time scales (Fig. 2). Miall (in press) explores the various autogenic and allogenic (respectively, equate to intra-basinal and extra-basinal) processes by which the "frozen accidents" achieve preservation.

Fragmentary the stratigraphic record might be, but the fractal nature of the record means that it consists of intervals of succession fragments separated by larger gaps that developed at higher time scales. These larger gaps constitute the boundaries between stratigraphic sequences. Several decades of analysis have now indicated that there is a limited number of sequence types, which develop because of the occurrence of particular allogenic processes that are characterized by particular time scales (Miall, 1995, 2010; Table 1). These natural time scales, because of their predominance, tend to lead to enhanced preservability, and it is for this reason that sequence stratigraphy "works." Miall (in press) proposes the definition of a suite of Sedimentation Rate Scales to encompass the range of time scales and processes that can now be recognized from modern studies of the stratigraphic record (Fig. 2).

In the absence of any techniques for the accurate dating of short-term events in the Precambrian it is difficult, if not impossible, to determine how the processes identified in Fig. 2 and Table 1 might have varied in duration and importance over the course of the 
Earth's history. It seems unlikely that there have been any changes in the physics of clastic sedimentation, so that, at the smaller, outcrop scale, few differences in clastic deposits may be expected through the Earth's history. Indeed, close-up images from Mars are indicative that at this scale the clastic record there is quite similar in facies.

\section{External (allogenic) controls at planetary or larger scale}

\subsection{Solar system mechanics and the Earth's rotation rate}

The length of the year implicit in geochronology is that of the tropical year (or solar year, from equinox to equinox) of 365.242 mean solar days (Allen, 1973; Gradstein et al., 2004). However, a changing gravitational constant $G$ would alter the scale and periods of the orbits of the planets and satellites, raising the question whether radiometric ages in years equate to the Earth's orbits around the Sun. J.G. Williams et al. (2004, p. 4) found that there was no discernible variation of $G$, and that cosmological expansion is not shared at the solar system scale; radiometric ages do thus equal Earth orbital revolutions.

Information on the Earth's palaeorotation and the past lunar orbit best comes from the analysis of sedimentary tidal rhythmites. Internally self-consistent palaeotidal data recorded by tidal rhythmites from the late Cryogenian (ca. $635 \mathrm{Ma}$ ) Elatina Formation in South Australia include $13.1 \pm 0.1$ synodic (lunar) months/yr, $400 \pm 7$ solar days/yr, a length of day of $21.9 \pm 0.4$ hours, and an Earth-Moon distance of $0.965 \pm 0.005$ of the present distance (Williams, 2000, 2004). The data indicate a mean rate of lunar recession since the late Cryogenian of $2.17 \pm 0.31 \mathrm{~cm} / \mathrm{yr}$ caused by tidal friction, little more than 
half the present rate of lunar recession of $3.82 \pm 0.07 \mathrm{~cm} / \mathrm{yr}$ obtained by lunar laser ranging (Dickey et al., 1994). An even lower rate of lunar recession in the early Precambrian is implied to avoid a catastrophic close approach of the Moon prior to $3 \mathrm{Ga}$ (Fig. 3), for which no geological evidence exists.

Secular change in the Earth-Moon system has influenced terrestrial sedimentary systems and has implications for global tectonics: (1) A decreasing frequency of powerful tides with time (ca. 30 spring tides/annum in the early Palaeoproterozoic, 26.2 in the late Cryogenian and 24.7 today; Williams, 2000, 2004). (2) A faster rotating Proterozoic Earth led to less efficient poleward transport of heat, with a slightly warmer equator and cooler poles (Kuhn et al., 1989; Jenkins, 1993), compounding the enigma of Proterozoic low-palaeolatitude glaciation. (3) The hypothesis that the orbital periods for precession and obliquity have increased with time due to secular increase in the Earth-Moon distance (Berger et al., 1989) is confirmed by the precession period of $19.6 \pm 1.1 \mathrm{kyr}$ and the obliquity period of $31.3 \pm 3.0 \mathrm{kyr}$ recorded by Late Ordovician-Early Silurian evaporites in Western Australia (Williams, 1991), compared to respective periods of 23 kyr and 41 kyr today. (4) Resonances of the Earth's fluid core with the semi-annual and annual forced nutations for the despinning Earth, estimated to have occurred more strongly in the Neoarchaean and around $530 \mathrm{Ma}$, respectively, would have amplified core motions and possibly increased the flux of mantle plumes and tectonothermal activity at those times (Williams, 1994, 2004). (5) The Elatina palaeotidal data indicate no overall change in the Earth's moment of inertia since the late Cryogenian, ruling out secular change in the Earth's radius at least since that time (Williams, 2000, 2004). 


\subsection{Change from mantle-domination to plate-domination in the Earth's geodynamics}

While few would dispute there was a change from an earlier mantle-dominated Earth to one where plate tectonics became paramount, the timing of this gradation remains contentious. Some argue for a very early onset of plate regimes (e.g., de Wit, 1998; de Wit and Hynes, 1995), thereby making the debate on timing peripheral to the preserved continental crustal and sedimentary record, whereas others see this transition as being significantly later (at ca. $2.0 \mathrm{Ga}$; e.g., Hamilton, 1998). Both short-period and longer-term secular changes and significant variations in geological processes argue against a simple transition of the Earth's geodynamic evolution along a continuous trend. Problems with strict interpretation of uniformitarian plate-tectonic models when applied to the Neoarchaean and Proterozoic record have been noted (e.g., Hoffman, 1989; Bickford and Hill, 2007; Stern, 2008), and Mints (this volume, and references therein) discusses specific examples of apparent complexity in the evolution of the Earth's geodynamics. The latter include a possible sudden turning-point in crust-forming processes in the Neoarchaean, as well as an alternative model for intracontinental formation of granulitegneiss belts with protoliths of metasedimentary and metavolcanic granulites filling depressions above mantle plumes, rapidly followed by high-grade metamorphism (e.g., Mints, 2007; Mints and Konilov, 2004; Mints et al., 2007).

The antiquity of the supercontinent cycle forms the subject of a parallel debate, equally unresolved (e.g., Unrug, 1992; Rogers, 1996; Aspler and Chiarenzelli, 1998). The inherent link (e.g., Zhong et al., 2007; Santosh et al., 2009) between this unresolved question and the mantle plume concept (viz. Condie, 2004 a, b; Condie et al., 2001) 
suggests that the supercontinent cycle was generated by the interaction of both mantle thermal and plate tectonic regimes. The debate is further complicated by possible globalscale tectonic-thermal "slowdowns" from ca. 2.45-2.2 Ga, and at ca. 1.4 Ga (Condie, 1998; Condie et al., 2009a). It has been suggested that the first (ca. 2.45-2.2 Ga) event even separated an early form of plate regime interacting with a higher energy mantle system, from the onset of truly Phanerozoic-style plate tectonics from ca. 2.2-2.0 Ga. Eriksson and Catuneanu (2004) argued for a gradual transition from the HadeanArchaean Earth dominated by magmatic processes to one where plate tectonics increasingly interacted with mantle thermal processes, possibly close to the ArchaeanProterozoic boundary; they stressed the possible relevance of Trendall's (2002) "plughole model" for such a gradual transition. However, the issues raised by Mints (this volume) should possibly be superimposed on this simple, gradational model of the Earth's evolution.

While many scientists see supercontinentality becoming almost pervasive by the Neoarchaean (or even earlier) (e.g., Aspler and Chiarenzelli, 1998), others caution against a global-scale onset for this paradigm, arguing instead for the coexistence of one (e.g., "Kenorland" espoused in the Aspler and Chiarenzelli, 1998 view) or more (e.g., Bleeker, 2003) supercontinents with cratons which were not yet part of such amalgamations, with Kaapvaal being one possible such example (e.g., Eriksson et al., 2011 a and b). Mints (this issue) employs data from the Palaeoproterozoic and Meso-Neoproterozoic of Lavroscandia and from other continents, to argue that a long-lived supercontinent (or group of large continents) possibly played the main role in the evolution and growth of the continental crust from ca. 2.80 to ca. $1.0 \mathrm{Ga}$ or maybe even to ca. $0.55 \mathrm{Ga}$ (Fig. 4). 


\section{Internal (autogenic) sedimentary controls on the planetary scale}

\subsection{Introduction}

Autogenic controls on sedimentation reflect the interplay of geospheric processes within the Earth system (hydrosphere, atmosphere, biosphere). Chemical sedimentary rocks best record such feedbacks because their deposition directly reflects oceanatmosphere chemistry, climate, weathering, nutrient cycling, and biologic evolution. Thus, variations in feedback rates regulating these factors govern the type and abundance of chemical sedimentary deposits through time (Fig. 5).

The most significant change in chemical sedimentation occurred during the Great Oxidation Event (GOE) between 2.4 and 2.3 Ga (e.g., Bekker et al., 2004; Canfield, 2005; Holland, 2006; Guo et al., 2009; Bekker and Holland, 2012; Pufahl and Hiatt, 2012). The GOE recorded the global expansion of oxygenic photosynthesis in cyanobacteria (Fig. 5; Cloud, 1973; Canfield, 2005; Saito, 2009), the disappearance of reduced detrital minerals such as pyrite and uraninite (Cloud, 1968; Fleet, 1998; England et al., 2002; Hazen et al., 2008) and the concomitant appearance of the large continental margin iron formations, phosphorites, and red beds (Holland, 2002; Bekker et al., 2010; Papineau, 2010; Pufahl, 2010; Pufahl and Hiatt, 2012). Although a number of processes likely preconditioned the atmosphere to accumulate oxygen (Kasting et al., 1979; Des Marais et al., 1992; Catling et al., 2001; Godderis and Veizer, 2004; Zahnle et al., 2006; Konhauser et al., 2009; Papineau, 2010), the most important was probably the switch from reducing to oxidizing volcanic gases (Kump et al., 2001; Holland, 2002). The GOE 
irreversibly changed the nature of the Earth system and paved the way for all subsequent keystone changes in chemical sedimentation (Fig. 5).

\subsection{Volcanic outgassing and volcanic record}

Since the formation of the Earth a steady cooling of the core and mantle is assumed (e.g., Vlaar et al., 1994; Lenardic et al., 2005; Korenaga, 2006, 2008; Herzberg and Gazel, 2009; Herzberg et al., 2010), reflected in the decreasing Mg content of high temperature, ultramafic magmas with time (Skulski et al., 2004): komatiites (>18\% MgO; commonly thought to have originated from deep-seated mantle plumes; Campbell et al., 1989; Arndt et al., 2008) were common in the Archaean, komatiitic basalts (13-18\% $\mathrm{MgO})$ in the Proterozoic, and picrites (10-13\% $\mathrm{MgO})$ in the Phanerozoic.

The secular compositional changes in volcanic rocks can also be found in their erosional products (shales and sandstones; e.g. Schwab, 1978) with trends for sedimentary and igneous rocks (komatiites, basalts, andesites, felsic extrusive rocks, and granites) showing that they changed sympathetically (Migdisov et al., 2003). The abundance of Mg-bearing mineral phases decreased from the Early Archaean to the Phanerozoic and those of K-bearing minerals and, in part, quartz increased with time.

Closely related to the changes in magma composition is also the change in magmatic volatile composition and volcanic outgassing that closely affected seawater chemistry as well as the composition of the atmosphere (Fig. 5). The most abundant gases that are released by volcanic systems and are being added to the atmosphere-ocean system today, are $\mathrm{H}_{2} \mathrm{O}, \mathrm{CO}_{2}$ and $\mathrm{SO}_{2}$, followed by smaller amounts of $\mathrm{H}_{2} \mathrm{~S}, \mathrm{H}_{2}, \mathrm{CO}, \mathrm{HCL}, \mathrm{HF}$, and $\mathrm{He}$ 
(Symonds et al., 1994; Giggenbach, 1996). These gases are removed from the system by the deposition of organic matter and carbonate minerals $\left(\mathrm{CO}_{2}\right.$ and $\left.\mathrm{CO}\right)$, sulphide and sulphate minerals $\left(\mathrm{H}_{2} \mathrm{~S}\right.$ and $\left.\mathrm{SO}_{2}\right)$, and by the reduction of $\mathrm{CO}_{2}$ and $\mathrm{CO}$ to organic matter, the reduction of $\mathrm{SO}_{2}$ to sulphides, and by loss into interplanetary space $\left(\mathrm{H}_{2}\right.$; cf., Holland, 2002).

Probably the most dramatic change in gas chemistry took place between 2470 and $2450 \mathrm{Ma}$ (Kump et al., 2001), when intense magmatic plume activity culminated in a large igneous province recognized on several continents (Barley et al., 1997; Heaman, 1997). During this time, an initially more reduced upper mantle became progressively more oxidized due to the release of reduced volcanic gases (probably mainly $\mathrm{H}_{2}$ and $\mathrm{CO}$ ) and subduction of hydrated, oxidized seafloor. This mantle overturn may have changed the redox state and therefore the oxygen fugacity $\left(f \mathrm{O}_{2}\right)$ of volcanic gases, taking the system through the crossover point to an oxic environment and eventually the GOE (Fig. 5; Kump et al., 2001; Holland, 2002). In the Phanerozoic, high rates of seafloor spreading and their related increased atmospheric pCO2 through volcanic outgassing as well as lower oceanic $\mathrm{Mg} / \mathrm{Ca}$ through intensified hydrothermal alteration of basalt, is hypothesized to have caused the change from aragonite to calcite seas (Mackenzie and Pigott, 1981; Sandberg, 1983; Stanley and Hardie, 1998; Kump, 2008; Hasiuk, 2008).

\subsection{Secular changes in carbonate sedimentation}

The connection between photosynthesis, increasing oxygen, the delivery of sulphate to the oceans, and resulting change of carbonate mineralogy is the first-order secular change 
in carbonate sedimentation. Carbonates in the Archaean and Proterozoic were largely formed by evaporative processes and, like chert, were chemical precipitates strongly influenced by microbial processes (Fig. 6). Precambrian carbonate rocks are almost exclusively dolomite (Fig. 7), probably due to evolving seawater chemistry (Fairbridge, 1957; Tucker, 1982; Given and Wilkinson, 1987; Warren, 2000; Machel, 2004). Low sulphate concentrations led to greater dolomite precipitation (e.g., Zentmyer et al., 2011) as sulphate kinetically inhibits dolomite formation (Baker and Kastner, 1981; Morrow and Rickets, 1988; Morrow and Abercrombie, 1994). The removal of $\mathrm{SO}_{4}{ }^{2-}$ occurs via the precipitation of sulphate minerals or by bacterial sulphate reduction, a relationship supported by association of dolomite in evaporative environments or with sulphide minerals (particularly in peritidal evaporative environments; Fig. 6; Zentmyer et al., 2011). In shallow settings where evaporation concentrated silica, abiogenic chert also precipitated (Maliva et al., 1989, 2005; Zentmyer et al., 2011). Weathering of sulphide minerals in the presence of oxygen produced $\mathrm{SO}_{4}{ }^{2-}$, which accumulated in the oceans following the GOE (Canfield, 1998; Habicht et al., 2002; Poulton et al., 2004). Although it is widely believed that the Earth's early oceans had low sulphate concentrations, the actual levels are debated (e.g., Walker and Brimblecombe, 1985; Grotzinger and Kasting, 1993; Knauth, 2005).

Proterozoic carbonate sedimentary rocks are also characterized by non-actualistic sedimentary structures, reflecting ocean water that was oversaturated with respect to $\mathrm{CaCO}_{3}$, and include giant ooids (Sweet and Knoll, 1989) and aragonite fans (Sumner and Grotzinger, 2004), which only reappear in the Phanerozoic record following major extinction events (Fig. 5; Grotzinger and Knoll, 1999). The Phanerozoic saw a revolution 
in which Eukaryotic biomineralization forever changed the nature of carbonate sedimentation (Fig. 5).

\subsection{Biologic evolution and chemical sedimentation}

Throughout the history of life, innovations in the metabolic processes essential to the growth, reproduction, survival, and evolution of organisms have been a primary control on the Earth's surface processes, the cycling and sequestration of nutrients, and the precipitation of minerals forming chemical sediments. Arguably the most important of these innovations was oxygenic photosynthesis in cyanobacteria. Although photosynthesis is deeply rooted in the tree of life, stretching back to the early Archaean (e.g., Hohmann-Marriott and Blankenship, 2011), oxygenic photosynthesis evolved much later. Biomarker evidence suggests cyanobacteria may have evolved by $2.9 \mathrm{Ga}$ (Nisbet et al., 2007) and were abundant by 2.7 Ga (Brocks et al., 2003a and b, 2005; Canfield, 2005; Schopf, 2006; Buick, 2008), ca. 400 Myr before the GOE. This lag is interpreted to record a period when oxygen-consuming, inorganic and organic reactions prevented the rise of photosynthetic oxygen. The onset of the GOE resulted in the accumulation of oxygen-dependent lithofacies, Mn-oxides, iron formations, phosphorites and glauconites (Roy, 1997; Nelson et al., 2010; Pufahl, 2010), and later allowed for the evolution and diversification of Eukaryotes (Fig. 5; Knoll, 2011).

By ca. $1.85 \mathrm{Ga}$ the bacterial reduction of seawater $\mathrm{SO}_{4}{ }^{2-}$ is thought to have created widespread euxinia, causing the demise of continental margin iron formation (Canfield, 1998; Poulton et al., 2004; 2010) and phosphorite (Nelson et al., 2010; Pufahl and Hiatt, 
2012). Such conditions are interpreted to have lasted for nearly a billion years (the "Boring Billion", with dramatic slowing of Eukaryotic evolution; Anbar and Knoll, 2002) and were likely perpetuated by anoxygenic photoautotrophs that tempered oxygen production by using $\mathrm{H}_{2} \mathrm{~S}$ as an electron acceptor (Johnston et al., 2009). Iron formation and phosphorite reappeared in the Neoproterozoic during several glaciations between 740 and $630 \mathrm{Ma}$ (Klein, 2005; Bekker et al., 2010; Pufahl, 2010).

A second major increase in photosynthetic oxygen at ca. $580 \mathrm{Ma}$, the Neoproterozoic Oxygenation Event (Fig. 5; Och and Shields-Zhou, 2012), ventilated the deep oceans creating the necessary conditions for forming the first true phosphorite giants (Pufahl, 2010; Pufahl and Hiatt, 2012) and oxygen concentrations rose to levels that led to the diversification of multicellular animals (Canfield et al., 2007; Och and Shields-Zhou, 2012). The diversification of mobility and feeding modes amongst late Ediacaran-early Cambrian metazoans (McIlroy and Logan, 1999; Erwin et al., 2011) had a dramatic effect on the physical and chemical nature of marine sediments. Thus, the Ediacaran-Cambrian transition was marked by an increase in bioturbation intensity (Droser and Bottjer, 1988), a "substrate revolution" (Bottjer et al., 2000) which drastically reduced the thickness and distribution of previously ubiquitous microbial facies and mats (Garrett, 1970; Hagadorn and Bottjer, 1997). Consequently, Phanerozoic seafloors developed large mixed layers with higher water contents, which produced an increasingly heterogeneous sedimentwater interface (Seilacher and Pflüger, 1994; Hagadorn and Bottjer, 1997; Seilacher, 1999; Plotnick et al., 2010). Biomineralization by Eukaryotes was another major innovation of the Ediacaran-Cambrian radiation (Weiner and Dove, 2011). 
Although older examples of biomineralizing metazoans are known (Porter and Knoll, 2000; Cohen et al., 2011), the Ediacaran-Cambrian radiation (Erwin et al., 2011) marked a widespread appearance of skeletonized taxa in the form of calcified tubes (e.g., Cloudina; Germs, 1972) and an array of bilaterian plates, spines and shells (Bengtson, 1992; Maloof et al., 2010). Diversification in biomineralizing organisms was followed by an increase in overall skeletal contribution to shallow-water carbonate facies in the Ordovician, especially by heavily calcified corals, bryozoans, brachiopods, and echinoderms (Pruss et al., 2010). The subsequent evolution of biomineralizing foraminifera (benthic in the Devonian and planktonic in the Jurassic; Hart et al., 2002) and coccolithophores (Triassic) significantly affected carbonate facies distribution by transferring carbonate deposition offshore (Tucker, 1985; Milliman, 1993; Erba, 2006). The Cenozoic explosion of silicifying diatoms severely limited the abundance of silica in surface oceans (Maliva et al., 1989), and may have led to a decrease in silica available for sponges and radiolarians (Lazarus et al., 2009).

The removal of organisms via mass extinctions also profoundly influenced chemical sedimentation (e.g., Payne et al., 2007) with the largest Phanerozoic mass extinction at the end-Permian (Erwin, 1993, 2001; Shen et al., 2011; Payne and Clapham, 2012) returning many carbonate depositional systems to Proterozoic-style sedimentation regimes (Grotzinger and Knoll, 1995; Knoll et al., 1996; Pruss et al., 2004). 


\section{Greenstone belt sedimentation}

Pre-rock record sedimentation ( $>4 \mathrm{Ma}$ ) was probably dominated by meteoritic and cometary impact events (cf., Schoenberg et al., 2002) causing very large tsunamis, resulting in very coarse volcaniclastic detritus combined with fine dust settling out of suspension, all reworked by marine current systems and localised turbidites (Eriksson et

al., 2007). ${ }^{182} \mathrm{~W} /{ }^{184} \mathrm{~W}$ ratios of Isua metasediments suggest derivation of the parent lithologies from meteorite debris (Willbold et al., 2011). Simonson et al. (2004) suggested that at least 6 spherule-layers bear testimony to global-scale impact events in rocks older than $3.2 \mathrm{Ga}$.

Basement-cover relationships in older and younger greenstone belts (Blenkinsop, 1993; Buick et al., 1995; Bleeker, 2003), epiclastic sedimentary rocks associated with volcanic successions (Mueller and Corcoran, 1998; Corcoran and Mueller, 2007), and abundant, compositionally mature siliciclastic sedimentary rocks (e.g., Krapez and Barley, 1987; Eriksson, et al., 1997; Hessler and Lowe, 2006) provide evidence for exposed land masses and continental weathering. The majority of Mesoarchaean quartz arenite successions are considered to have been deposited on stable continental shelves along rifted margins (Thurston and Chivers, 1990; Eriksson et al., 1994; Mueller et al., 2005), but quartz-rich deposits of fault-controlled, high relief Mesoarchaean (e.g., Krapez, 1996) and Neoarchean (Corcoran et al., 1998) successions are mainly a function of source composition (granodiorite) and intense chemical weathering under reducing atmospheric conditions. These conditions are supported by a paucity of clays and feldspars in Archaean clastic deposits, in addition to which mudstones from the Fig Tree 
and Moodies Groups (Barberton belt, Kaapvaal) and from the Gorge Creek and Roebourne Megasequences, Pilbara Block, Australia are enriched in aluminum relative to average shales (Eriksson and Soegaard 1985; Hessler and Lowe, 2006).

Recognizable sedimentary processes in greenstone belts include debris flows on highgradient alluvial fans, mid-channel bar formation and unconfined sheetflood deposition in low-sinuosity, gravel- and sand-dominated braided rivers, wind ripple and dune migration in aeolian settings, tidal and wave reworking in shallow-marine environments, and deposition from turbulent flows (e.g., Eriksson, 1977, 1979; Eriksson et al., 1994; Heubeck and Lowe; 1994; Corcoran and Mueller, 2004; Mueller et al., 2005; Long, 2011). The predominance of low-sinuosity braided to the exclusion of high-sinuosity meandering fluvial deposits is compatible with high runoff rates linked to steep gradients, related to a lack of bank stabilization in the absence of land plants (Schumm, 1961; Davies and Gibling, 2011; Long, 2011). Unconfined runoff may have been more prominent than stream flow processes as a result of interstratification with erosionresistant, felsic volcanic flows (Mueller and Corcoran, 2001). Steep gradients and high runoff rates promoted the formation of braid deltas rather than river deltas at the landocean interface. Quantitative analysis of tidal sand waves in the Moodies Group, South Africa reveals the presence of semi-diurnal, diurnal and fortnightly signals and implies that tidal current velocities for these deposits were within the range for modern tides (Eriksson and Simpson, 2000).

Maximum water depths of sedimentation are difficult to constrain from the preserved sedimentary record in greenstone belts. The predominance of shallow-water facies does not necessarily imply that Archaean oceans in general were shallow; on the contrary, 
estimates of average Archaean ocean depths are circa $2.6 \mathrm{~km}$ (Bickle et al., 1994). Siliciclastic turbidites in the Fig Tree Group, South Africa do not necessarily record abyssal depths, as the presence of hummocky cross-stratification in this succession suggests that maximum depths did not exceed tens of metres. It is thought unlikely that secular changes exist for deep water sedimentation, although the prominent controls on deposition during the Archaean may have been tectonic rather than eustatic.

Non-clastic sedimentary rocks in greenstone belts record chemical and biological processes different from those operating in later geological time (discussed in section 4). The significance of Archaean barite is controversial. Lowe (1983) and Buick and Dunlop (1990) consider barite in the Warrawoona Supersequence to be pseudomorphous after gypsum that formed as a normal evaporite from seawater of comparable composition to that of today. Grotzinger and Kasting (1993), in contrast, argue that calcium would have been exhausted before the gypsum field was reached with little or no precipitation of calcium sulphate except near sites of continental runoff from weathering of basalts. In addition to calcium, Archaean seawater also was enriched in $\mathrm{Fe}^{++}$. Upwelling of reducing bottom waters into zones of oxygen productivity resulted in precipitation of iron oxides. Such iron formations are most common in the stable-shelf successions preserved in younger greenstone belts $(<3.0 \mathrm{Ga})$ in the Slave and Superior Provinces, Canada, the Yilgarn Block, Australia and in Zimbabwe (e.g., Blenkinsop, 1993; Bleeker, 2003; Wyche et al., 2004; Mueller et al., 2005). Sulphidic iron formations likely developed below the pycnocline and Eriksson (1983) has likened Archaean iron formations to Holocene pelagic sediment rainout. 


\section{Earliest cratonic sedimentation}

The 4.4 Ga zircons in Australian Meso- or Palaeoarchaean fan-delta metaconglomerates are the first clear evidence for a stable felsic continental crust (Eriksson and Wilde, 2010; Wilde et al., 2001); oxygen isotopes in these zircons provide definitive evidence for a hydrosphere (Cavosie et al., 2005), with lithium isotopes indicating intense weathering of Eoarchaean continental crust in a $\mathrm{CO}_{2}$-rich environment at elevated temperatures (Ushikubo et al., 2008). The area of continental crust exposed to weathering prior to 3.2 Ga was probably insignificant (Shields, 2007; Bradley, 2011), allied also to high global sea levels (Flament et al., 2011), explaining the absence of extensive terrestrial and shallow marine deposits in Eoarchaean (3.6-4.03 Ga) and Palaeoarchaean (3.2-3.6 Ga) strata. Minor terrestrial strata are present in the Mesoarchaean (2.8-3.2 Ga) of Kenorland (Donaldson and de Kemp, 1998; Breaks et al., 2001), but are more prominent in the Neoarchaean $(2.5-2.8 \mathrm{Ga})$, where alluvial fan and braided river deposits occur in small foreland (Corcoran and Mueller, 2007), piggyback (Kusky and Kidd, 1992; Devaney, 2000), and late transtensional "Timiskaming-type" basins (Mueller and Corcoran, 1998; Bleeker et al., 1999; Eriksson and Wilde, 2010; Corcoran, 2012). Shallow marine quartz-rich strata tend to be preserved in extensional or sag basins (Blight 1985), or where directly associated with komatiites or other mafic lavas, along rifted passive margins (Sakurai et al., 2005; Corcoran, 2012).

The Kaapvaal craton was amongst the earliest to stabilize globally, and hosts the Earth's oldest known large basin, including significant placer gold (Frimmel et al., 2005). Despite a complex geodynamic history (Robb and Meyer, 1995a, b), the craton may not 
have been part of a larger supercontinental assemblage during deposition of the Witwatersrand basin, and a sub-Kaapvaal plume may have influenced craton accretion (cf., model of De Wit et al., 1992), formation of a complex flexural foreland basin (Catuneanu, 2001) and enhanced gold provenance (Eriksson et al., 2009, 2011a). Large braided systems, terminating in braid-deltas, debouched directly into a shallow epeiric sea on the distal craton (Els and Mayer, 1992, 1998; Catuneanu, 2001).

Within what became the Kenorland supercontinent (Aspler and Chiarenzelli, 1998), numerous thin successions of quartz-rich sandstones indicate stable shallow water platformal sedimentation (Ojakangas, 1985; Donaldson and de Kemp, 1998). In the Mesoarchaean of the Slave Province, a quartz arenite dominated succession of tide influenced chromite- and fuchsite-bearing sandstones, locally associated with ultramafic flows and sills, and typically overlain by banded iron formations (Bleeker et al., 1999; Corcoran, 2012), are consistent with transgression on a rifted continental margin. Within the Mesoarchaean and Neoarchaean of the Superior Province (Ojakangas, 1985; Donaldson and de Kemp, 1998), and Baltic Shield (Thurston and Kozhevnikov, 2000), there are numerous examples of similar quartz-rich sandstones, mostly of shallow marine origin and constrained to narrow, linear basins. Evidence of extensive carbonate deposition within Kenorland is limited to deposits within the Steep Rock Group that formed on top of a volcanic plateau (Fralick et al., 2008). The major differences in basin and sedimentation style between possible isolated cratons, like the Kaapvaal, and larger continental amalgamations, like Kenorland were probably linked to differences in tectonic control of basin evolution and freeboard, as outlined by Eriksson and Condie (2012). 


\section{Alluvial sedimentation and secular change}

Major secular changes in fluvial style have been driven by variations in atmosphere chemistry, Earth's surface temperature, weathering regime, and most significantly the onset and evolution of terrestrial vegetation (Long, 2011). During the early Hadean (ca. 4.5-4.567 Ga) the Earth's surface was probably molten, with initial terrestrial deposits being dominated by minor talus, loess and aeolian dunes. As surface temperatures dropped to below $100^{\circ} \mathrm{C}$ at approximately $4 \mathrm{Ga}$ (Eriksson et al., 2007), temporary accumulations of water would have permitted development of fluvial- and debris flowdominated alluvial fans, lakes and fan-deltas, as can be seen on the surface of Mars (Buhler et al., 2011; R.M.E. Williams et al., 2011) and Venus (Jones and Pickering, 2003). All evidence for these early terrestrial facies on the Earth was probably destroyed by the end of the period of heavy bombardment, at approximately $3.9 \mathrm{Ga}$. Although the paucity of $>3.2 \mathrm{Ga}$ lacustrine deposits is a function of poor preservation, the relatively small number of documented Mesoarchaean (2.8-3.2 Ga) and Neoarchaean (2.8-2.5 Ga) examples is probably the result of difficulties in distinguishing between marine and fresh water units in the absence of biological indicators.

Palaeoarchaean (3.2-3.6 Ga) and Mesoarchaean fluvial deposits are poorly represented in the rock record. Most fluvial strata of this age include high gradient alluvial fan deposits with evidence of debris flows (Breaks et al., 2001; Eriksson and Wilde, 2010). Many of the associated sandstone units tend to be planar bedded, implying deposition under upper flow regime conditions. Fralick and Carter (2011) argue that elevated surface temperatures during the Archaean would have significantly reduced the viscosity of 
water, generating a thinner viscous sublayer, consequently suppressing ripple formation in sands coarser than fine sand. Dune formation does not appear to have been suppressed, as abundant trough cross-stratification has been recorded in braided fluvial strata at the base of the Mesoarchaean Bababudan Group by Srinivasan and Ojakangas (1986).

By the Neoarchaean (2.5-2.8 Ga) both fan and braided river deposits are better represented, both in transtensional (Corcoran, 2012; Corcoran et al., 1998, 1999; Driese et al., 2011), rift-related, platformal and foreland basin settings (Els, 1998a; Karpeta and Els, 1999; Minter, 1999; Eriksson et al., 2001; Corcoran and Mueller, 2007). Many of the more extensive fluvial systems may have had the form of distributary fan systems (Els, 1998b; Cain and Mountney, 2009; Hartley et al., 2010). As Neoarchaean river banks were not stabilized by plants, width to depth ratios of braided rivers would have been significantly greater, perhaps locally exceeding 1000:1 (Els, 1990). Overbank deposits have not been reported, but lake or pond deposits were present locally, as evidenced by abrupt lithofacies transitions from trough cross-bed - dominated, coarse-grained sandstone and clast-supported, stratified conglomerate to local siltstone-mudstone units containing wave ripples, graded beds and dewatering structures (Krapez, 1984; Mueller et al., 1994; Corcoran et al., 1999; Corcoran and Mueller, 2004). Although most described lacustrine units are laterally restricted, an extensive lake system has been identified in the Tumbiana Formation, Fortescue Group (Buick, 1992; Awramik and Buchheim, 2009). Microbial material may have accumulated in ephemeral ponds in channel thalwegs (Mossman et al., 2008) and in soils (Driese et al., 2011).

Long (2011) provides a comprehensive review of pre-vegetation fluvial systems, with emphasis on the Proterozoic. He noted that due to the absence of rooted vascular plants 
most pre-vegetation systems have features that are more closely allied to modern ephemeral and dryland systems. Sand-bed and gravel-bed braided systems are common, and have architecture similar to that of modern systems, except that scour hollows are typically absent or difficult to identify. Sandy braided systems are dominated by composite barforms with predominantly downstream accretionary elements. Sandy ephemeral channelized upper-flow-regime elements, and unconfined sheetflood deposits are common, but lack many of the associated fine-grained components seen in modern systems. Sandy meandering systems can be identified, based on up-section changes in palaeoflow vectors, but typically lack the fining-upward trends seen in modern systems. Overbank deposits are rare, except in marginal marine systems. Point-bars in rare cobblegrade gravel-bed meandering systems were apparently wider and had lower inclination than modern systems. Wandering gravel-bed rivers, low-sinuosity sandy braided systems with alternate bars, and fine-grained meandering and anabranching systems have not been positively identified. Documented lacustrine deposits are more prevalent in the early to middle Proterozoic than the Archaean (Collinson and Terwindt, 1983; Eriksson, 1991; Martins-Neto, 1996).

The progressive colonization of terrestrial environments by rooted plants in late Silurian to middle Devonian times significantly affected microclimate by modifying albedo and moisture retention in soils, leading to a greater role of organic acids in decomposition of labile components (Jutras et al., 2009). This led to increased production and subsequent trapping of clay minerals in overbank settings. Davies and Gibling (2010a, b) suggest that the initial colonization of land by complex plants (embrophytes) took place between 472 and $436 \mathrm{Ma}$, but had little effect on fluvial style. The first 
advanced vascular plants appear to have evolved in the late Llandovery (Davies and Gibling, 2010a, b). These lacked penetrative roots and were restricted to lowland settings, so had minimal effect on bank stabilization, but may have led to a slight increase in mud retention in overbank settings (Davis and Gibling, 2010b). Davis and Gibling (2010a, 2011) suggest that a transition from predominantly sheet-braided to channel-braided fluvial systems may have occurred at this time. Heterolithic meandering stream deposits, with well-developed lateral accretions sets, are first reported from the late Silurian; they became far more abundant with the development of substantial plant root systems in the Early Devonian.

The onset of advanced terrestrial vegetation systems, including trees, in Middle Devonian tropical to boreal settings marks the first development of extensive forests and extensive stable mud-rich overbank settings. Davies and Gibling (2011) suggest that the continued evolution and expansion of trees and rooted plants in the Carboniferous led to the generation of low-gradient, avulsion prone, organic-rich, fixed multi-channel anastomosed (anabranching) river systems, due to increased root stabilization of river banks and development of extensive riparian and in-channel vegetation. The rapid expansion of grasses into dryland and well drained upland environments during the Cenozoic (Strömberg, 2011) is liable to have had a profound effect on fluvial styles, especially in ephemeral systems as it would baffle overland flows, and possibly enhance rill development. 


\section{Aeolian sedimentation and secular change}

Millimetre- to cm-scale inversely graded strata generated by wind-ripple migration provide an unequivocal means for distinguishing subaerial from subaqueous depositional processes and thereby enable the recognition of aeolian processes in continental settings (Hunter, 1977, 1981; Kocurek and Dott, 1981; Fryberger and Schenk, 1988) or even on Mars (Grotzinger et al., 2005). Based on these criteria, the oldest recognized evidence of aeolian deposition is from the 3.2 Ga Moodies Group of South Africa (Simpson et al., 2012). Other notable Archaean examples of wind processes are ventifacts associated with placer deposits in the 2.9 Ga Witwatersrand Supergroup, South Africa (Minter, 1976; 2006) and sand-sheet deposits composed of aeolian stratification from the 2.6 Ga Minas Supergroup of Brazil (Martins-Neto and Costa, 1985). Reports of Proterozoic and younger aeolianites are more commonplace and probably reflect alternative controls on formation and preservation than those that occurred before ca. 1.8 Ga. (Eriksson and Simpson, 1998; Simpson et al., 2004b).

Early evolved biological soil crust (BSC)-like communities played an important role in the early biological invasion of Precambrian continental landscapes, where they stabilized land surfaces and reduced the flux of sediment into aeolian systems (Campbell, 1979; Belnap et al., 2001; Prave, 2002; Retallack, 2008; Beraldi-Campesi et al., 2009; Finkelstein et al., 2010; Simpson et al., 2010; Beraldi-Campesi and Garcia-Pichel, 2011; Malenda et al., 2012). The oldest recognized BSCs cluster around ca. 1.2 Ga (Prave, 2002; Beraldi-Campesi and Garcia-Pichel, 2011; Beraldi-Campesi et al., 2009); algal mat related roll-up features are reported in $1.8 \mathrm{Ga}$ interdune deposits (Eriksson et al., 2000) 
and organic signatures are inferred from $\delta^{13} \mathrm{C}$ and bulk rock chemistry in Neoarchaean soils (Watanabe et al., 2000). The paucity of reported examples of Archaean aeolianites suggests the possibility that microbes may have been more important in stabilizing the land surface than previously recognized. The absence of vegetative cover in the Precambrian would generally have enhanced sediment flux (Dott, 2003) which dynamically links fluvial and aeolian systems over different time scales of months to Milankovich periodicities (Clemmenson et al., 1989; Kocurek, 1991, 1996, 1999; Lancaster, 1997; Howell and Mountney, 1997; Chan and Archer, 1999; Loope et al., 2001; Swezey, 2001; Bullard and Livingstone, 2002; Veiga et al., 2002; Scherer and Lavina, 2005; Kocurek and Ewing, 2005).

With higher fluxes of sediment to and from the aeolian systems in the Precambrian, aeolian deposits likely extended across a wider range of climate regimes than today (Eriksson and Simpson, 1998; Simpson et al., 2004b); as a result, we argue that large dune fields and associated facies are the best indicators of deserts in the early rock record. One of the best examples is the Palaeoproterozoic Makgabeng Formation, Waterberg Group, South Africa which consists of dunefield deposits comprising of thick foresets and associated interdune deposits (Eriksson et al., 2000; Simpson et al., 2004a, b). Salinepan deposits separate the dunefield into two distinct ergs (Eriksson et al., 2000; Simpson et al., 2004a). These saline pan deposits preserve micro-evaporitic features, such as those reflecting solution collapse and that have direct analogues in modern saline pans, and are one of the oldest reported examples (Simpson et al., 2004a). Climate change terminated the youngest erg (Simpson et al., 2002) as evidenced by massive sandstones generated by extreme precipitation events that degraded dune lee faces before truncation by the 
overlying Mogalakwena Formation fluvial system (Simpson et al., 2002; Eriksson et al., 2008a).

Eriksson and Simpson (1998) argue that preservation of large-scale Precambrian aeolianites is possibly dependent on suitable tectonic settings of high accommodation during the early breakup of supercontinents and to a lesser degree on the assembly of supercontinents. Numerous semi-quantitative and quantitative predictive models for aeolian subfacies have been developed that examine the roles of subsidence (assumed to be linear within the short-term of the model), sediment availability, water table, and position of the accumulation surface (e.g., Mountney, 2006).

\section{Glacigenic sedimentation and secular change}

\subsection{Archaean and Palaeoproterozoic glaciations}

The oldest known glacigenic deposits occur in the Mozaan Group of the ca. 2.9 Ga Pongola Supergroup in southern Africa, with diamictites containing faceted and striated clasts and stratified siltstones with dropstones (Young et al., 1998; Crowell, 1999). Deposition occurred on a stable marine shelf. The apparent mean palaeolatitude of the Pongola Supergroup is ca. $30^{\circ}$ but the timing of magnetisation is poorly constrained (Strik et al., 2007).

Early Palaeoproterozoic glaciation is known from four continents, but their temporal relationship is unclear. In Canada, the ca. 2.4-2.2 Ga Huronian Supergroup records three

glaciations (Crowell, 1999; Young et al., 2001). Deposits of the 600-1700 m thick 
Gowganda Formation are the youngest and most widespread, covering at least $400 \times 200$ km, with correlates elsewhere in North America. Facies include massive diamictites, some with faceted and striated clasts, and rhythmites with dropstones and till pellets, deposited in a marine environment on the southern margin of the Canadian Shield (Mustard and Donaldson, 1987; Young et al., 2001). In Fennoscandia, glacial deposition occurred between 2.45 and $2.3 \mathrm{Ga}$ in an area of $300 \times 500 \mathrm{~km}$ (Crowell, 1999; Ojakangas et al., 2001). The Urkkavaara Formation in Finland and the Sariolian Group in adjoining Russia have metadiamictite and metasiltstone-argillite with dropstones. In South Africa, the Makganyene Formation (Transvaal Supergroup) is $50-150 \mathrm{~m}$ thick and formed after $2436 \pm 7 \mathrm{Ma}$ (youngest detrital zircon age; Moore et al., 2012); diamictites with striated clasts were deposited during a regressive, uplift phase. In Western Australia, glaciation between 2.45 and $2.20 \mathrm{Ga}$ is recorded by the $360 \mathrm{~m}$ thick Meteorite Bore Member of the Kungarra Formation and the Boolgeeda Iron Formation (Crowell, 1999; Martin, 1999); glacial facies include diamictites with faceted and striated clasts and outsized dropstones in fine-grained beds. A marine environment is envisaged.

Early Palaeoproterozoic glaciations in North America and Fennoscandia occurred in low palaeolatitudes while respective cratons moved across the palaeoequator (Williams and Schmidt, 1997; Schmidt and Williams, 1999; Bindeman et al., 2010). Palaeomagnetic data for $2.2 \mathrm{Ga}$ volcanics in South Africa imply the immediately underlying Makganyene Formation was possibly deposited at a palaeolatitude of $11 \pm 5^{\circ}$ (Evans et al., 1997). A low palaeolatitude is suggested for early Palaeoproterozoic glaciation in Western Australia (Evans, 2007). 
In NW Australia, subglacial channel-fills and glaciofluvial deposits occur at the base of the ca. $1.8 \mathrm{Ga}(<1869 \pm 7 \mathrm{Ma}$, youngest detrital zircon, Kirkland et al., 2010; $>1790 \pm 4$ Ma, SHRIMP U-Pb zircon age of intrusive dolerite, Page and Sun, 1994) marine King Leopold Sandstone (Williams, 2005). Glaciation reached close to sea level and coincided with orogeny in Australia and worldwide continental assembly. A low palaeolatitude $(8 \pm$ $2^{\circ}$ ) is indicated (Schmidt and Williams, 2008). Recognition of late Palaeoproterozoic glaciation overturned the view of a 2200-800 Ma nonglacial interval.

\subsection{Neoproterozoic glaciations}

Two Cryogenian glaciations recognised on most continents are commonly, but incorrectly, referred to as the "Sturtian" and "Marinoan" glaciations based on chronostratigraphic units in South Australia. Allen and Etienne (2008) termed this the "two-epoch paradigm", which carries the unproven assumption of the global synchronism of respective glaciations. They concluded that available data permit numerous Neoproterozoic glaciations from 780 to $580 \mathrm{Ma}$, with Cryogenian glaciation evidently ending at ca. 635 Ma.

Cryogenian glacial successions attain great thicknesses and cover wide areas. In South Australia, deposits of the middle to late Cryogenian Sturt glaciation are $>5 \mathrm{~km}$ thick (Preiss et al., 2011) and those of the younger, terminal Cryogenian Elatina glaciation cover 200,000 km² (G.E. Williams et al., 2008, 2011). Etienne et al. (2008, p. 343) found that Cryogenian glacial facies "are typical of sedimentary sequences deposited along glaciated continental margins throughout Earth history." Facies of the Elatina glaciation 
are particularly varied, ranging from permafrost regolith and periglacial sand sheet, through glaciofluvial, tidal and deltaic sandstones with wave-generated ripple marks, to inner and outer marine-shelf siltstones and diamictites indicating the widespread rainout of ice-rafted debris and several glacial advances and retreats. Cryogenian glaciation occurred in low palaeolatitudes, first firmly established for the Elatina glaciation (Schmidt et al., 1991; Schmidt and Williams, 1995); this datum is supported by positive soft-sediment fold tests and corrected for minor inclination shallowing due to compaction (Schmidt et al., 2009), and remains a benchmark for Cryogenian near-palaeoequatorial $\left(\leq 10^{\circ}\right)$ glaciation. Subsequent studies have yielded low palaeolatitudes for other Cryogenian glacigenic deposits, with most results between $0-20^{\circ}$ and no result $>40^{\circ}$ palaeolatitude (Evans and Raub, 2011).

Ediacaran (635-542 Ma) glaciation is recognised on most continents (Etienne et al., 2008; Gostin et al., 2010). The Gaskiers glaciation in Newfoundland is dated at ca. 580 Ma and the glacigenic Fauquier Formation in Virginia at ca. 571 Ma (Hebert et al., 2010), but without further radiometric ages their relation to glacial episodes elsewhere remains unclear. Ediacaran glaciation spanned wide palaeolatitudes: ice rafting and glacial deposition in Australia occurred at $10-15^{\circ}$ (Gostin et al., 2010) and glaciation elsewhere ranged from ca. $50^{\circ}$ to a favoured palaeolatitude of $78 \pm 12^{\circ}$ for the Fauquier Formation (Evans and Raub, 2011). The palaeolatitude of the Gaskiers glaciation is uncertain (Pisarevsky et al., 2012).

Exceptionally well preserved Cryogenian periglacial polygonal sand-wedges in West Africa (Deynoux, 1982) and South Australia (Williams and Tonkin, 1985; Williams et al., 2008) closely resemble sand wedges in Antarctica. They imply former mean annual 
air temperatures of -12 to $-20{ }^{\circ} \mathrm{C}$ or lower and a seasonal air temperature range of up to $40 \mathrm{C}^{\circ}$ (Washburn, 1980; Karte, 1983). Hence frigid, strongly seasonal Cryogenian climates existed near sea level in low palaeolatitudes. Wedges interpreted as periglacial occur in other Neoproterozoic and in Huronian glacigenic deposits (references in Williams, 1986).

\subsection{Phanerozoic glaciations}

Landing and MacGabhann (2010) suggested Early-Middle Cambrian glaciation of the Avalon microcontinent at a high palaeolatitude. Late Ordovician-Early Silurian glaciation from ca. 445-429 Ma, the world's oldest confirmed circum-polar glaciation, was brief but severe (Crowell, 1999). Ice sheets spread from the South Pole in NW Africa to adjoining South America as well as Europe and possibly North America, with grounded ice and periglacial wedges in South Africa at ca. $40^{\circ}$ palaeolatitude (Daily and Cooper, 1976; Cocks and Torsvik, 2002). Late Devonian and Early Carboniferous-Late Permian glaciations mark the drift of Gondwana and Pangaea across the South Pole (Caputo and Crowell, 1985; Fielding et al., 2008). Late Palaeozoic ice rafting extended to ca. $32^{\circ}$ palaeolatitude (Frakes and Francis, 1988), with Permian mountain glaciers in Colorado evidently descending to relatively low palaeoelevations on the palaeoequator (Soreghan et al., 2008). However, interpreted periglacial wedges near the palaeoequator in the Pennsylvanian-Permian of Colorado (Sweet and Soreghan, 2008) are unlike periglacial forms (see Black, 1983) and are better viewed as wedge-shaped seismites (e.g., Montenat et al., 2007). 
Outsized exotic clasts in mudstones are widespread in the Early Cretaceous of Australia and are known from the mid-Jurassic to mid-Cretaceous in Russia, Alaska, Canada and Spitsbergen (Frakes and Francis, 1988; Frakes et al., 1995). These are interpreted as ice-rafted deposits that formed at palaeolatitudes $>60^{\circ}$, implying the presence of high-latitude ice at sea level during the Mesozoic. Diamictite and associated lonestone facies in South Australia indicate Early Cretaceous glaciation at ca. $65^{\circ}$ palaeolatitude (Alley and Frakes, 2003).

Ice-rafted debris in early Cenozoic sediments from both southern and northern polar regions indicate glaciers at sea level back to 45 Ma (Dawber and Tripati, 2011) and possibly $58 \mathrm{Ma}$ in Spitsbergen (Frakes and Francis, 1988). Continental-scale glaciation was established in Antarctica by $34 \mathrm{Ma}$ and ice sheets in northern high latitudes by ca. 23 Ma (Tripati et al., 2005; DeConto et al., 2008). The Pleistocene continental ice sheets in North America reached a maximum southern limit of ca. $38^{\circ} \mathrm{N}$ (Stiff and Hansel, 2004).

\subsection{Controls and secular changes}

As summarised by Bradley (2011), no consistent relationship is evident between times of glaciation and major tectonism. Palaeozoic ice sheets formed on Gondwana and Pangaea whereas Cenozoic ice sheets formed on dispersed fragments of Pangaea. Some Proterozoic glacigenic deposits are associated with continental rifts and separation (Eyles, 2008), but rifting and subsidence would enhance their preservation thus giving the impression that glaciation is favoured by extensional settings. Moreover, two contrasting

global tectonic events in the latter history of the Earth - the 1.3-1.0 Ga Grenville 
orogeny and the late Palaeozoic-early Mesozoic breakup of Pangaea - have no known related glaciation.

The outstanding features of the glacial record are the low palaeolatitudes of preEdiacaran glaciations and the switch to circum-polar glaciations of the Phanerozoic (Fig. 8; Williams, 1993, 2008), with several Palaeoproterozoic glaciations coinciding with drift across the palaeoequator and Palaeozoic glaciations with drift of Gondwana and Pangaea across polar regions. This switch spanned the Ediacaran-early Palaeozoic and the advent of the Metazoa. Palaeomagnetic data accord with the geomagnetic field approximating a geocentric axial dipole during the Proterozoic (Schmidt, 2001; Smirnov and Tarduno, 2004) and probably for all of geological time (McElhinny, 2004), hence palaeolatitudes may be viewed as indicators of geographic latitudes.

Although pre-Ediacaran high-palaeolatitude glacigenic deposits are unknown, the "snowball Earth" hypothesis postulates global glaciation during the Cryogenian with ca. $3 \mathrm{~km}$ thick synchronous ice-sheets on all continents and a shut-down of the hydrological cycle (Hoffman and Schrag, 2002; Domack and Hoffman, 2011). However, a large and diverse body of data conflicts with the requirements and predictions of this hypothesis (e.g., Kennedy et al., 2001; Allen and Etienne, 2008; Williams, 2008; Sansjofre et al., 2011). The Elatina glaciation, for example, was marked by extensive and long-lived open seas, unglaciated continental regions and an active hydrological cycle (Williams et al., 2008). Etienne et al. (2008) concluded that Cryogenian glacial facies require neither global synchronism nor necessarily severe climatic excursions.

Alternatively, an obliquity of the ecliptic $>54^{\circ}$ would render the equator cooler than the poles, on average, and amplify global seasonality, so offering an explanation of all 
pre-Ediacaran low-palaeolatitude glaciations and related strong seasonality (Williams, 1993, 2008; Jenkins, 2003). Modelling indicates that a high obliquity is a likely outcome of the Moon-producing single giant impact at $4.5 \mathrm{Ga}$, but there is no established mechanism to reduce the obliquity during the Ediacaran-early Palaeozoic to accommodate Phanerozoic circum-polar glaciation. Pre-Ediacaran low-palaeolatitude glaciation thus remains a first-order geological and geophysical enigma.

\section{Littoral-shelf (epeiric) sedimentation and secular change}

Due to the complexity of early plate tectonics and a concomitant long history of deformation and reworking of craton margins, marine successions from Precambrian cratons are strongly skewed towards better preserved epeiric sea deposits on the cratons themselves rather than at their margins (e.g., Eriksson et al., 1998; 2004b) and few modern examples of epeiric seas exist (e.g., Pratt and Holmden, 2008). Clastic successions interpreted as epeiric seaways (essentially shelf-like with strongly directional currents) compare relatively favourably with modern shallow ocean and shelf settings while Precambrian epeiric embayments (lacked shelf breaks and ocean-type currents) were significantly smaller and shallower (Brenner, 1980; Eriksson et al., 2004b, 2008b).

Reduced shelf gradients of many Precambrian epeiric seas promoted predominant tidal energy at the expense of storms/waves (cf., Pratt and James, 1986), as also inferred from extensive peritidal flat deposits identified in the shoaling portions of Phanerozoic-aged epeiric basins (e.g., Swett et al., 1971; Reading, 1978; Pratt and James, 1986; Friedman et al., 1992). Precambrian clastic epeiric sea coastlines were typified by high energy braid- 
delta systems (Els, 1998a; Eriksson et al., 2008b) and in wave-dominated coastal segments away from these largely tidally reworked braid-deltas, amalgamation of supralittoral storm beds may have been important (Sarkar et al., 2004). Deposition, erosion and even stratigraphic architecture within Precambrian marine realms are thought to have been heavily dependent on prolific and widespread microbial mat growth (which flourished in the absence of grazers and burrowers), both in siliciclastic and carbonate supralittoral-littoral-shelf settings (e.g., Schieber, 1998; Schopf, 1999; Hagadorn and Bottjer, 1999; Schieber et al., 2007; Noffke, 2010; Sarkar et al., 2008).

Precambrian clastic shelf (cf., shelf-like epeiric) deposits tend to be sandy and to closely mirror Phanerozoic-Modern equivalents (Jackson et al., 1990; Lindsey and Gaylord, 1992; Eriksson et al., 1998), with common hummocky and swaley cross-strata, parallel laminae, trough and planar cross-bedding (Soegaard and Eriksson, 1985; Bose et al., 1988; Jackson et al., 1990; Tirsgaard and Sønderholm, 1997; see, however, some significant exceptions detailed by Sarkar et al., 2005, 2008; Catuneanu and Eriksson, 2007). Inferred open shelf deposits are typically dominated by wave-imprinted nearshore sandstones and massive to laminated mudrocks ( \pm subordinate storm-deposited graded siltstone/fine-grained sandstone beds) and exhibit remarkable preservation of small-scale primary features due to a lack of bioturbation (Schieber, 1989; Chakraborty and Bose, 1992; Sarkar et al., 2002). Very mature shoreface sandstones lack mudstone but show localised pebbles and pebble lags (Harris and Eriksson, 1990; Walker and Plint, 1992; Eriksson et al., 1998). Although literature on Precambrian barrier island, wash-over fan (Eriksson, 1979) and lagoonal deposits is restricted (e.g., Eriksson et al., 1998), Sarkar et al. (2008) have recorded tidal accentuation behind localized shoals. Case studies of 
Precambrian epeiric basins are given by Bose et al. (1999, 2001), Chakraborty (2002), Simpson et al. (2004b), Sarkar et al. (2002, 2004, 2005) and Eriksson et al. (2008b).

\section{Discussion}

\subsection{Secular change, sequence stratigraphy and actualism}

The principles of sequence stratigraphy are the same irrespective of the age of the strata under analysis. It was generally assumed that conclusions drawn from the earlier study of the Phanerozoic record would be universally applicable to strata of all ages, following the principle of actualism. The more recent applications of sequence stratigraphy to the Precambrian record indicate, however, that the window of time provided by the Phanerozoic is insufficient for meaningful generalizations (e.g., Eriksson et al., 2004a; Catuneanu et al., 2005). Notwithstanding practical limitations imposed by the lesser preservation and poorer time control, the Precambrian stratigraphy enlarges significantly our window into the geological past and affords better insights into some of the first principles of sequence stratigraphy.

The principle of actualism as applied to sequence stratigraphy was placed under scrutiny in recent years (e.g., Eriksson et al., 2004a; Catuneanu et al., 2005, 2012). It is now accepted that both similarities and differences exist between the controls on sequence development and the patterns of sedimentation within Precambrian and Phanerozoic depositional settings. 
In terms of similarities, the same set of allogenic controls on sedimentation and sequence development operated throughout geological time and lead to marked similarities with respect to preserved lithologies, sedimentary structures, and the association of sedimentary facies and depositional elements within Precambrian and Phanerozoic sedimentary basins (cf., Eriksson et al., 1998; Altermann and Corcoran, 2002). Contrasts between Precambrian and Phanerozoic sedimentary successions are caused by a variety of factors that changed in terms of nature, rates and intensities during the course of the Earth's history, as have been detailed in preceding sections of this paper.

The combined effect of the secular changes detailed above contributed to differences in the scale and architecture of Precambrian sequences when compared with Phanerozoic counterparts, including the relative contribution of various systems tracts to the makeup of a sequence (e.g., Sarkar et al., 2005; Catuneanu, 2007). These observations provide clues that help in the refining of critical aspects of the sequence stratigraphic method, from the development of a system of sequence hierarchy to understanding the shifts in sequence stratigraphic architecture through time.

In terms of sequence hierarchy, the critical aspect is that the rates and to some extent the nature of basin-forming mechanisms have changed during the Earth's evolution, from a greater measure of competing plume tectonics and plate tectonics in the Precambrian to a more stable plate-tectonic regime in the Phanerozoic (Eriksson and Catuneanu, 2004; Eriksson et al., 2005a, b). The more erratic tectonic regimes, in terms of nature and rates, which controlled the formation and evolution of sedimentary basins in the Precambrian indicate that time is largely irrelevant to the classification of stratigraphic sequences (Catuneanu et al., 2005). Instead, it is rather the record of changes in the tectonic setting 
that provides the means for the subdivision of the stratigraphic record into basin-fill successions separated by first-order sequence boundaries. These first-order basin-fill successions are in turn subdivided into second- and lower-rank sequences that result from shifts in the balance between accommodation and sedimentation at various scales of observation, irrespective of the time span between two same-order consecutive events.

In terms of sequence architecture, shifts with time in environmental-energy conditions and in the role of microbial mats on sedimentation may explain observed changes in the relative development of systems tracts within sequences of different ages (Catuneanu, 2007). Notably, the Precambrian sequences lack well-developed transgressive systems tracts, and are dominated by stacked highstand systems tracts that may be separated by thin veneers of transgressive deposits, often reduced to transgressive lags (e.g., Banerjee and Jeevankumar, 2005; Sarkar et al., 2005). The poorer development of transgressive systems tracts in the Precambrian may be attributed to higher wind and wave energy conditions, promoting stronger wave-ravinement erosion during transgression, possibly related to a greater polarization of the Earth's thermal zones (Rautenbach, 2001) combined with enhanced global rotation rates (Williams, 2000, 2004) (section 3.1). The prevalence of highstand systems tracts may be attributed to the prolific growth of microbial mats below the fairweather wave-base in shelfal settings, particularly during the Proterozoic, which prevented the reworking of sediments by the organic binding of particles and promoted aggradation under normal regressive conditions (e.g., Sarkar et al., 2005). 


\subsection{Significant and irreversible change in the nature of the Earth system: Neoarchaean}

Postulated effects of secular change in the Earth's mechanics on global tectonics may have been more extreme at two specific periods in the Earth's history: strong resonances of the Earth's fluid core with the semi-annual and annual forced nutations for the despinning Earth in the Neoarchaean and at ca. 530 Ma might explain the inferred higher flux of mantle plumes and tectonothermal activity at these times (Williams, 1994). It is even conceivable that the significant apparent change in crust-forming processes in the Neoarchaean was related to the semi-annual resonance. Comparably, zircon $\mathrm{U}-\mathrm{Pb}$ age peaks support episodic rapid crustal growth rates, with the most prominent peak at 2.82.7 Ga, thus also suggesting a sharp and sudden turning-point in crust-forming processes in the Neoarchaean (section 3).

A complex interaction between plume and plate tectonic processes for much of the Proterozoic (Mints, this volume) can also be linked inherently to the supercontinent cycle (e.g., Condie et al., 2001; Condie, 2004 a, b; Zhong et al., 2007; Santosh et al., 2009). While some see the onset of this cycle as being of uncertain antiquity, Condie (2001) and Condie et al. (2009b) considered that increased production rates of juvenile crust, starting at ca. 2.7 Ga, correlate with the formation of supercontinents and superplume events. The ongoing and multi-faceted debate is expanded by postulated global-scale tectonicthermal "slowdowns" from ca. 2.45-2.2 Ga, and at ca. $1.4 \mathrm{Ga}$ (Condie, 1998; Condie et al., 2009a). It can also be hypothesized that the earlier slowdown event may even have separated an early form of plate regime interacting with a higher energy mantle system, from the onset of a more recognisable Phanerozoic-style plate tectonic regime from ca. 
2.2-2.0 Ga. While there is a widespread belief in almost pervasive supercontinentality from the Neoarchaean (e.g. Aspler and Chiarenzelli, 1998; Bleeker, 2003), a more diachronous onset may have applied, with coexistence of supercontinents and nonamalgamated cratons (e.g. Eriksson et al., 2011a, b).

11.3. Significant and irreversible change in the nature of the Earth system: Palaeoproterozoic

Probably the most significant change in chemical conditions on the Earth was the Great Oxidation Event (GOE) (e.g., Bekker et al., 2004; Canfield, 2005; Holland, 2006; Guo et al., 2009; Bekker and Holland, 2012; Pufahl and Hiatt, 2012), the rise in atmospheric oxygen between 2.4 and $2.3 \mathrm{Ga}$ which paralleled the global expansion of oxygenic photosynthesis in cyanobacteria (Cloud, 1973; Bekker et al., 2004; Canfield, 2005; Holland, 2006; Guo et al., 2009; Saito, 2009; Bekker and Holland, 2012; Pufahl and Hiatt, 2012). The preceding ca. $2470-2450$ Ma interval was marked by intense plume activity terminating in a widespread LIP (large igneous province; Barley et al., 1997; Heaman, 1997) which led to a dramatic switch from reducing to oxidizing volcanic gases (Kump et al., 2001; Holland, 2002). The ca. 2450 Ma age is the same as that inferred for the onset of Condie et al.'s (2009a) global magmatic slowdown.

The onset of the GOE not only led to the disappearance of reduced detrital minerals (e.g., pyrite, uraninite) from the sedimentary rock record (Cloud, 1968; Fleet, 1998; England et al., 2002; Hazen et al., 2008), but also to the accumulation of oxygendependent lithofacies like Mn-oxides, phosphorites and glauconites, and red beds (Roy, 
1997; Holland, 2002; Bekker et al., 2010; Nelson et al., 2010; Papineau, 2010; Pufahl, 2010; Pufahl and Hiatt, 2012); later, it also enabled the evolution and diversification of eukaryotes (Fig. 5; Knoll, 2011). The GOE thus irreversibly changed the nature of the Earth system and led to subsequent major changes in chemical sedimentation (Fig. 5). Archaean and Proterozoic carbonates were largely of an evaporative origin, with significant influences from microbial processes. Fe-rich dolomite gave way to iron-poor dolomites during the Neoarchaean-Mesoproterozoic period; a change accompanied by a gradual secular increase in limestone (e.g., Bose et al., 2012) (Fig. 7).

A broader range of palaeoclimatic zones is inferred from the NeoarchaeanPalaeoproterozoic transitional period, and warm and humid climates may well have predominated up till at least ca. $2.3 \mathrm{Ga}$, accompanied by reduction in acid-rain effects and decrease in greenhouse gasses, especially marked after ca. $2.2 \mathrm{Ga}$. However, evidence for Palaeoproterozoic glaciation is preserved on four continents, but the temporal relationship of the deposits (spread across more than $200 \mathrm{Myr}$, between ca. 2.45 and $2.2 \mathrm{Ga}$ ) remains unclear. Evidence for continent-marginal marine settings for glacial deposition is strong and generally, palaeolatitudes appear to have been low, coeval with host cratons or supercontinents like Kenorland moving across the palaeoequator (e.g., Williams and Schmidt, 1997; Schmidt and Williams, 1999; Bindeman et al., 2010).

Long's (2011) study of pre-vegetational fluvial systems indicates that they most probably closely resembled modern ephemeral and dryland systems with common sandbed and gravel-bed braided systems; unconfined sheetflood deposits were abundant, with some sandy meandering systems but not fine-grained meandering and anabranching systems, and overbank deposits were rare. Documented lacustrine deposits become more 
prevalent in the Palaeo- to Mesoproterozoic (e.g., Collinson and Terwindt, 1983; Eriksson, 1991; Martins-Neto, 1996). The development of advanced terrestrial vegetation systems in the Middle Devonian allowed extensive stable mud-rich overbank settings for the first time on the Earth. The lack of vegetation, and its presence and evolution during the Phanerozoic eon were thus both absolutely critical factors in the development of fluvial systems and their secular changes through the planet's history.

\subsection{The "Boring Billion"?}

Widespread euxinia (inferred to reflect bacterial reduction of oceanic $\mathrm{SO}_{4}{ }^{2-}$ ) by ca. $1.85 \mathrm{Ga}$ is postulated to have ended iron formation and phosphorite deposition (Canfield, 1998; Poulton et al., 2004; 2010; Nelson et al., 2010; Pufahl and Hiatt, 2012) and ushered in the so-called "boring billion" year period which followed. During this time, anoxygenic photoautotrophs that tempered oxygen production by using $\mathrm{H}_{2} \mathrm{~S}$ as an electron acceptor (Johnston et al., 2009) are thought to have perpetuated euxinia and dramatically curtailed Eukaryotic evolution (Anbar and Knoll, 2002).

An earlier view of a nonglacial interval from 2200-800 Ma, approximately coincident with the "boring billion", was revised by documentation of ca. 1.8 Ga low latitude subglacial-fluvioglacial deposits in Australia, coincident with orogeny and global-scale continental assembly (Williams, 2005; Schmidt and Williams, 2008). On a greater geographical scale within the continental terranes, examples of Proterozoic and younger aeolianites become much more common than prior to the onset of the "boring billion", and may reflect different controls on formation and preservation than occurred prior to 
ca. 1.8 Ga (Eriksson and Simpson, 1998; Simpson et al., 2004b) (section 8). Eriksson and Simpson (1998) have argued for an association with supercontinental breakup (and to a lesser extent assembly) to provide high accommodation tectonic settings for extensive desert deposit preservation, with the oldest deposits clustering around $1.8-2.0 \mathrm{Ga}$. Preservation of extensive desert facies probably also requires large land masses at suitable palaeolatitudes (ca. $30^{\circ}$ ), thus dependent on the scale of continental assemblies. It is also inferred that Precambrian aeolian deposits most probably extended across a wider range of palaeoclimatic conditions than today (e.g., Eriksson and Simpson, 1998; Simpson et al., 2004b).

\subsection{Significant and irreversible change in the nature of the Earth system:} Neoproterozoic and beyond (Phanerozoic)

Both iron formations and phosphorites reappear in the Earth's sedimentary record in the Neoproterozoic, associated with some Cryogenian glaciations postulated at 740-630 Ma (Klein, 2005; Bekker et al., 2010; Pufahl, 2010). Although two Cryogenian glaciations are recognised on most continents, global synchronism is unproven, and the postulate of numerous Cryogenian to Ediacaran glaciations from 780 to 580 Ma may well be a better interpretation of the Neoproterozoic glacial record (Allen and Etienne, 2008). No palaeomagnetic result $>40^{\circ}$ palaeolatitude (Evans and Raub, 2011) has been found. Ediacaran (635-542 Ma) glaciation, also recognised on most continents (Etienne et al., 2008; Gostin et al., 2010), again lacks clear evidence of synchronism, but is distinguished by a wide palaeolatitudinal spread (e.g., Gostin et al., 2010; Evans and Raub, 2011). Phanerozoic 
glaciation marks the change to circum-polar glaciation, with a localized episode of relatively low-elevation equatorial mountain glaciation during the late Palaeozoic. While the postulate of an obliquity of the ecliptic $>54^{\circ}$ can account for all pre-Ediacaran low-palaeolatitude glaciation and related strong seasonality (Williams, 1993, 2008; Jenkins, 2003), supported by modelling indicating that a high obliquity is a likely outcome of the Moon-producing single giant impact at $4.5 \mathrm{Ga}$, no mechanism is known to reduce the obliquity during the Ediacaranearly Palaeozoic, in order to accommodate Phanerozoic circum-polar glaciation.

The Neoproterozoic Oxygenation Event at ca. 580 Ma (Fig. 5) spurred on the Ediacaran diversification of multicellular animals (Canfield et al., 2007; Och and ShieldsZhou, 2012), the succeeding Ediacaran-Cambrian transition, and the concomitant "substrate revolution" (Bottjer et al., 2000) which dramatically affected the physical and chemical nature of marine sediments. As another consequence, the dominance of microbial mats that characterised much of the preceding Precambrian was ended (Garrett, 1970; Hagadorn and Bottjer, 1997). Relatively widespread biomineralization by Eukaryotes at the Ediacaran-Cambrian radiation (Weiner and Dove, 2011) brought not only skeletonized taxa (Germs, 1972) but also the complex array of skeletal structures (Bengtson, 1992; Maloof et al., 2010) that strongly influenced shallow-water carbonate facies in the Ordovician (Pruss et al., 2010) and subsequent siliceous biomineralization (Fig. 5). 


\section{Conclusions}

In all considerations of secular change of sedimentation systems, the fragmentary nature of the sedimentary record must be borne in mind. Almost all sedimentary processes are essentially ephemeral and stratigraphic gaps, distribution of layer thicknesses and sedimentation rates all have an overall fractal character. It was particularly changes in the rates and intensities of controlling factors during the course of the Earth's history, rather than the factors themselves, that were responsible for contrasts between Precambrian and Phanerozoic sedimentary successions.

The Neoarchaean marks a sudden and sharp turning-point in crust-forming processes, with change in the Earth's mechanics and concomitant influences on global tectonics related to inferred peaks in the flux of mantle plumes and in tectonothermal activity, and the onset of the supercontinent cycle starting at ca. $2.7 \mathrm{Ga}$. In the succeeding Palaeoproterozoic, the combined changes had become both substantial and irreversible. The end of the ca. 2470-2450 Ma interval, a period characterized by intense plume activity, saw a dramatic change from reducing to oxidizing volcanic gases, which brought on the most meaningful change in the Earth's chemical conditions, the Great Oxidation Event (GOE; 2.4-2.3 Ga). Its inception was marked by the disappearance from the sedimentary rock record of reduced detrital minerals and by the onset of the accumulation of oxygen-dependent lithofacies. A global-scale tectono-thermal "slowdown", postulated from ca. 2.45-2.2 Ga possibly marked the divide between an early plate regime interacting with a higher energy mantle system, and a Phanerozoicstyle plate tectonic regime which became active from ca. 2.2-2.0 Ga. The "slowdown" 
period was also marked by the first global-scale glacial deposits of predominantly shallow marine affinity and inferred low palaeolatitudes.

The lack of vegetation in the Precambrian, and its presence and evolution during the Phanerozoic, were a prime secular control on the nature of, particularly, fluvial systems and their preserved deposits during the Earth's history. Development of large ergs and widespread palaeodeserts globally from ca. 2.0 - 1.8 Ga may reflect different controls on formation and preservation than occurred prior to that time, and an association with the supercontinent cycle is postulated. Precambrian aeolian deposits probably extended across a wider range of palaeoclimatic conditions than their modern equivalents.

A second period of significant and irreversible change occurred in the Neoproterozoic; iron formations and phosphorites reappear in the sedimentary record and several Cryogenian glaciations are inferred at 740-630 Ma. Similar to the global-scale glaciation in the Palaeoproterozoic, global synchronism is not proven, and low palaeolatitudes are determined. The analogously widespread Ediacaran glaciation (635-542 Ma) is marked, in contrast, by a wide palaeolatitudinal range, while Phanerozoic glaciation is circumpolar. It is notable that the change from low latitude to circum-polar glaciation corresponds with the Ediacaran-early Palaeozoic period and the advent of the Metazoa. The Neoproterozoic Oxygenation Event (ca. $580 \mathrm{Ma}$ ) and concomitant Ediacaran diversification of multicellular animals were succeeded by the Ediacaran-Cambrian transition, and allied dramatic changes to the physical and chemical nature of marine sedimentation.

Major changes at the global-scale, such as the "Great Oxidation Event" or a widespread low palaeolatitude glaciation event, would have interacted with local-scale 
conditions (such as regional tectonic setting, rate of change of relative sea level, palaeomicroclimate perhaps defined by local tectonic setting, unique biological character etc.) and as a result, the imposition of the global event on the nature of the local rock record might have been delayed. The preservation of such global events would thus plausibly have been diachronous at the local, especially outcrop scale. When taken together with the inherently fragmentary nature of the sedimentary rock record of the Earth as a whole, global synchroneity of major events across preserved successions on different cratons will be unlikely. This essentially diachronous character of the rock record when studied at the field-scale should thus not be taken as an indication of an event with broad temporal distribution, but rather as an inherent preservational character of a short-term global event within the sedimentary record as it is implicitly studied from field outcrops.

\section{Acknowledgements}

Ed Simpson and Ken Eriksson acknowledge research support by National Geographic Society grant 6003-97, and wish to thank Mr. Nico Oosthuyzen for permission to work in the Songimvelo game preserve and Mr. Roelf Le Roux of Barberton Mines for aid on various aspects of their work in the famous Barberton greenstone belt. Peir K. Pufahl, Eric E. Hiatt and Marc Laflamme were supported by a NSERC Discovery Grant and PetroCanada Young Innovator Award to PKP, a University of Wisconsin-Oshkosh University Research Program Grant to EEH, a Smithsonian Institution Postdoctoral Fellowship and NASA National Astrobiology Institute Grant to ML. Nils Lenhard 
acknowledges a University of Pretoria Research Development Program (RDP) Grant. Pat Eriksson thanks this same University, and the National Research Foundation of South Africa for research funding, and Thino Rajab for her drafting skills. We acknowledge two anonymous reviewers and guest editor Tim Kusky, for their sage advice.

\section{References}

Ager, D. V., 1973. The nature of the stratigraphical record. John Wiley, New York, 114 p.

Ager, D. V., 1993. The new catastrophism. Cambridge University Press, Cambridge U.K., 231 p.

Allen, C.W., 1973. Astrophysical Quantities ( $3^{\text {rd }}$ edn). Athlone Press, University of London, $310 \mathrm{p}$.

Allen, P.A., Etienne, J.L., 2008. Sedimentary challenge to Snowball Earth. Nature Geoscience 1, 817-825.

Alley, N.F., Frakes, L.A., 2003. First known Cretaceous glaciation: Livingston Tillite Member of the Cadna-owie Formation, South Australia. Australian Journal of Earth Sciences 50, 139-144. 
Altermann, W., Corcoran, P.L. (Eds.), 2002. Precambrian Sedimentary Environments: A Modern Approach to Ancient Depositional Systems. International Association of Sedimentologists Special Publication 33, Blackwell, Oxford, 450 p.

Anbar, A.D., Knoll, A.H., 2002. Proterozoic ocean chemistry and evolution: a bioinorganic bridge? Science 297, 1137-1142.

Arndt, N.T., Lesher, C.M., Barnes, S.J., 2008. Komatiite. Cambridge University Press, Cambridge, U.K., 467 p.

Aspler, L.B., Chiarenzelli, J.R., 1998. Protracted breakup of Kenorland, a Neoarchean supercontinent? Geochronologic, tectonostratigraphic and sedimentologic evidence from the Paleoproterozoic. Sedimentary Geology 120, 75-104.

Awramik, S.M., Buchheim, H.P., 2009. A giant, Late Archean lake system: The Meentheena Member (TumbianaFormation; Fortescue Group),Western Australia. Precambrian Research 174, 215-240.

Bailey, R. J., Smith, D. G., 2005. Quantitative evidence for the fractal nature of the stratigraphic record: results and implications. Proceedings of the Geologists' Association $116,129-138$. 
Bailey, R. J., Smith, D. G., 2010. Scaling in stratigraphic data series: implications for practical stratigraphy. First Break 28, 57-66.

Baker, P. A., Kastner, M., 1981. Constraints on the formation of sedimentary dolomite. Science 213, 215-216.

Banerjee, S., Jeevankumar, S., 2005. Microbially originated wrinkle structures on sandstones and their stratigraphic context: Paleoproterozoic Koldaha shale, central India. Sedimentary Geology 176, 211-224.

Barley, M.E., Pickard, A.L., Sylvester, P.J., 1997. Emplacement of a large igneous province as a possible cause of banded iron formation 2.45 billion years ago. Nature 385 , 55-58.

Barrell, J., 1917. Rhythms and the measurement of geologic time. Geological Society of America Bulletin 28, 745-904.

Bekker, A., Holland, H.D., 2012. Oxygen overshoot and recovery during the early Paleoproterozoic. Earth and Planetary Science Letters 317, 295-304

Bekker, A., Holland, H.D., Wang, P.-L., Rumble III, D., Stein, H.J., Hannah, J.L., Coetzee, L.L., Beukes, N.J., 2004. Dating the rise of atmospheric oxygen. Nature 427, 117-120. 
Bekker, A., Slack, J.F., Planavsky, N., Krapež, Hofmann, A., Konhauser, K.O., Rouxel, O.J., 2010. Iron formation: the sedimentary product of a complex interplay among mantle, tectonic, oceanic, and biospheric processes. Economic Geology 105, 467-508.

Belnap, J., Kaltenecker, J.H., Rosentreter, R., Williams, J., Leonard, S., Eldridge, D., 2001. Biological soil crusts: ecology and management: United States Department of Interior, Technical Reference 1730-2, $110 \mathrm{p}$.

Bengtson, S., 1992. Proterozoic and earliest Cambrian skeletal metazoans, In Schopf, J.W., Klein, C. (Eds.), The Proterozoic Biosphere: A multidisciplinary study. Cambridge University Press, Cambridge, UK, pp. 397-411.

Beraldi-Campesi, H., Garcia-Pichel, F., 2011. The biogenicity of modern terrestrial rollup structures and its significance for ancient life. Geobiology 9, 10-23.

Beraldi-Campesi, H., Hartnett, H.E., Anbar, A., Gordon, G.W., Garcia-Pichel, F., 2009. Effect of biological soil crusts on soil elemental concentrations: implications for biogeochemistry and as traceable biosignatures of ancient life on land. Geobiology 7, 348-359.

Berger, A., Loutre, M.F., Dehant, V., 1989. Pre-Quaternary Milankovitch frequencies. Nature 342, 133. 
Bickford, M.E., Hill, B.M., 2007. Does the arc accretion model adequately explain the Paleoproterozoic evolution of southern Laurentia? An expanded interpretation. Geology $35,167-170$.

Bickle, M.J., Nisbet, E.G., Martin, A., 1994. Archaean greenstone belts are not oceanic crust. Journal of Geology 102, 121-138.

Bindeman, I.N., Schmitt, A.K., Evans, D.A.D., 2010. Limits on hydrosphere-lithosphere interaction: origin of the lowest-known $\delta^{18} \mathrm{O}$ silicate rock on Earth in the Paleoproterozoic Karelian rift. Geology 38, 631-634.

Black, R.F., 1983. Pseudo-ice-wedge casts of Connecticut, northeastern United States. Quaternary Research 20, 74-89.

Blackwelder, E., 1909. The valuation of unconformities. Journal of Geology 17, 289-299.

Bleeker, W., 2003. The late Archean record: a puzzle in ca. 35 pieces. Lithos 71, 99-134.

Bleeker, W., Ketchum, J.W.F., Jackson, V.A., Villeneuve, M.E., 1999. The Central Slave Basement Complex, part 1: its structural topology and autochthonous cover. Canadian Journal of Earth Sciences 36, 1083-1109. 
Blenkinsop, T.G., 1993. An ensialic origin for the Ngezi Group, Belingwe Greenstone Belt, Zimbabwe. Geology 21, 1135-1138.

Blight, D.F., 1985. Economic potential of the Lower Fortescue Group and adjacent units in the southern Hamersley basin: a study of depositional environments. Geological Survey of Western Australia, Report 13, 25p +2 plates.

Bose, P.K., Chaudhuri, A.K., Seth, A., 1988. Facies, flow and bedform patterns across a storm-dominated inner continental shelf: Proterozoic Kaimur Formation, Rajasthan, India. Sedimentary Geology 59, 275-293.

Bose, P.K., Chakraborty, S., Sarkar, S., 1999. Recognition of ancient eolian longitudinal dunes: a case study in Upper Bhander Sandstone, Son Valley, India. Journal of Sedimentary Research 69, 86-95.

Bose, P.K., Sarkar, S., Chakraborty, S., Banerjee, S., 2001. Overview of the Meso- to Neoproterozoic evolution of the Vindhyan basin, central India. Sedimentary Geology $141-142,395-419$.

Bose, P.K., Eriksson, P.G., Sarkar, S., Wright, P., Samanta, P., Mukhopadhyay, S., Mandal, S., Banerjee, S., Altermann, W., 2012. Sedimentation patterns during the Precambrian: a unique record? Marine and Petroleum Geology 33, 34-68. 
Bottjer, D.J., Hagadorn, J.W., Dornbos, S.Q., 2000. The Cambrian substrate revolution. GSA Today 10, 1-7.

Bradley, D.C., 2011. Secular trends in the geologic record and the supercontinent cycle. Earth-Science Reviews 108, 16-33.

Breaks, F.W., Osmani, I.A., de Kemp, E.A., 2001. Geology of the North Caribou Lake area, northwestern Ontario.Ontario Geological Survey, Open File Report 6023, 80p.

Brenner, R.L., 1980. Construction of processes-response models for ancient epicontinental seaway depositional systems using partial analogs. American Association of Petroleum Geologists Bulletin 64, 1223-1244.

Brocks, J.J., Buick, R., Summons, R.E., Logan, G.A., 2003a. A reconstruction of Archean biological diversity based on molecular fossils from the $2.78-2.45$ billion year old Mount Bruce Supergroup, Hamersley Basin, Western Australia. Geochimica et Cosmochimica Acta 67 (22), 4321-4335.

Brocks, J.J., Buick, R., Logan, G.A., Summons, R.E., 2003b. Composition and syngeneity of molecular fossils from the 2.78 to 2.45 billion-year-old Mount Bruce Supergroup, Pilbara Craton, Western Australia. Geochimica et Cosmochimica Acta 67(22), 4289-4319. 
Brocks, J.J., Love, G.D., Summons, R.E., Knoll, A.H., Logan, G.A., Bowden, S.A., 2005. Biomarker evidence for green and purple sulphur bacteria in a stratified Palaeoproterozoic sea. Nature 437(7060), 866-870.

Buhler, P.B., Fassett, C.I., Head, J.W., Lamb, M.P., 2011. Evidence for paleolakes in Erythraea Fossa, Mars: implications for an ancient hydrological cycle. Icarus 213, 104115.

Buick, R., 1992. The antiquity of oxygenic photosynthesis: evidence from stromatolites in sulphate-deficient Archaean lakes. Science 255, 74-77.

Buick, R., 2008. When did oxygenic photosynthesis evolve? Philosophical Transactions of the Royal Society B 363, 2731-2743.

Buick, R., Dunlop, J.S.R., 1990. Evaporitic sediments of Early Archaean age from the Warrawoona Group, North Pole, Western Australia. Sedimentology 37, 247-277.

Buick, R., Thornett, J.R., McNaughton, N.J, Smith, J.B., Barely, M.E., Savage, M., 1995. Record of emergent continental crust $\sim 3.5$ billion years ago in the Pilbara Craton of Australia. Nature 375, 574-577.

Bullard, J.E., Livingstone, I., 2002. Interactions between aeolian and fluvial systems in dryland environments. Area 34, 8-16. 
Cain, S.A., Mountney, N.P., 2009. Spatial and temporal evolution of a terminal fluvial fan system: the Permian Organ Rock Formation, South-east Utah, USA. Sedimentology $56,1774-1800$.

Campbell, I.H., Griffith, R.W., Hill, R.I., 1989. Melting in an Archaean mantle plume: heads it's basalts, tails it's komatiites. Nature 339, 697-699.

Campbell, S.E., 1979. Soil stabilization by prokaryotic desert crust: implications for Precambrian land biota. Origins of Life 9, 335-348.

Canfield, D. E., 1998. A new model for Proterozoic ocean chemistry. Nature 396, 450453.

Canfield, D.E., 2005. The early history of atmospheric oxygen: homage to Robert M. Garrels. Annual Review of Earth and Planetary Science 33, 1-36.

Canfield, D.E., Poulton, S.W., Narbonne, G.M., 2007. Late-Neoproterozoic deep-ocean oxygenation and the rise of animal life. Science 315, 92-95.

Caputo, M.V., Crowell, J.C., 1985. Migration of glacial centres across Gondwana during Paleozoic era. Geological Society of America Bulletin 96, 1020-1036. 
Carlson, R.W., Pearson, D.G., James, D.E., 2005. Physical, chemical, and chronological characteristics of continental mantle. Reviews of Geophysics 43, 1-24.

Catling D.C., Zahnle, K.J., McKay, C.P., 2001. Biogenic methane, hydrogen escape, and the irreversible oxidation of early Earth. Science 293, 839-843.

Catuneanu, O., 2001. Flexural partitioning of the Late Archaean Witwatersrand foreland system, South Africa. Sedimentary Geology 141/142, 95-112.

Catuneanu, O., 2006. Principles of sequence stratigraphy. Elsevier, Amsterdam, 375 p.

Catuneanu, O., 2007. Sequence stratigraphic context of microbial mat features, In: Schieber, J., Bose, P.K., Eriksson, P.G., Banerjee, S., Sarkar, S., Altermann, W., Catuneanu, O. (Eds.), Atlas of Microbial Mat Features Preserved within Siliciclastic Rock Record. Atlases in Geoscience 2, pp. 276-283.

Catuneanu, O., Eriksson, P.G., 2007. Sequence stratigraphy of the Precambrian. Gondwana Research 12, 560-565.

Catuneanu, O., Martins-Neto, M.A., Eriksson, P.G., 2005. Precambrian sequence stratigraphy. Sedimentary Geology 176, 67-95. 
Catuneanu, O., Martins-Neto, M.A., Eriksson, P.G., 2012. Sequence stratigraphic framework and application to the Precambrian. Journal of Marine and Petroleum Geology $33,26-33$.

Cavosie, A.J., Valley, J.W., Wilde, S.A., 2005. Magmatic $\delta^{18} \mathrm{O}$ in $4400-3900$ Ma detrital zircons: a record of the alteration and recycling of crust in the Early Archean. Earth and Planetary Science Letters 235, 663- 681.

Chakraborty, C., Bose, P.K., 1992. Rhythmic shelf storm beds: Proterozoic Kaimur Formation, India. Sedimentary Geology 77, 259-268.

Chakraborty, S., 2002. Sedimentation sequence of the three youngest members of the Vindhyan Supergroup, central India. PhD thesis (unpublished), Jadavpur University, Kolkata, India, 150p.

Chan, M.A., Archer, A.W., 1999. Spectral analysis of eolian foreset periodicities implications for Jurassic decadal-scale paleoclimatic oscillators. Palaeoclimates 3, 239255.

Clemmenson, L.B., Øxnevad, I.E.I., Boer, P.L., 1989. Climate control on ancient desert sedimentation: some Paleozoic and Mesozoic examples from NW Europe and western interior of the USA, In: Boer, D.L., Smith, D.E., (Eds.), Orbital Forcing and cyclic 
sequences. International Association of Sedimentologists Special Publication 19, pp. 439458.

Cloud, P.E., 1968. Atmospheric and hydrospheric evolution on the primitive Earth. Science 160, 729-736.

Cloud, P.E., 1973. Paleoecological significance of the banded iron-formation. Economic Geology 68, 1135-1143.

Cocks, L.R.M., Torsvik, T.H., 2002. Earth geography from 500 to 400 million years ago: a faunal and palaeomagnetic review. Journal of the Geological Society, London 159, $631-644$.

Cohen, P.A., Schopf, J.W., Butterfield, N.J., Kudryavtsev, A.B., Macdonald, F.A., 2011. Phosphate biomineralization in mid-Neoproterozoic protists. Geology 39(6), 539-542.

Collinson, J.D., Terwindt, J.H.J., 1983. Sedimentology of unconformities within a fluviolacustrine sequence; middle Proterozoic of eastern North Greenland. Sedimentary Geology 34, 145-166.

Condie, K.C., 1998. Episodic continental growth and supercontinents: a mantle avalanche connection? Earth and Planetary Science Letters 163, 97-108. 
Condie, K. C., 2001. Mantle Plumes and Their Record in Earth History. Cambridge University Press, Cambridge, UK, 305p.

Condie, K.C., 2004a. Precambrian superplume events, In: Eriksson, P.G., Altermann, W., Nelson, D.R., Mueller, W.U., Catuneanu, O. (Eds.), The Precambrian Earth: Tempos and Events. Developments in Precambrian Geology 12, Elsevier, Amsterdam, pp. 163-173.

Condie, K.C., 2004b. Supercontinents and superplume events: distinguishing signals in the geological record. Physics of the Earth and Planetary Interiors 146, 319-332.

Condie, K.C., Des Marais, D.J., Abbott, D., 2001. Precambrian superplumes and supercontinents: a record in black shales, carbon isotopes and paleoclimates? Precambrian Research 106, 239-260.

Condie, K.C., O’Neill, C., Aster, R., 2009a. Evidence and implications for a widespread magmatic shutdown for 250 My on Earth. Earth and Planetary Science Letters 282, 294298.

Condie, K.C., Belousova, E., Griffin, W.L., Sircombe, K.N., 2009b. Granitoid events in space and time: constraints from igneous and detrital zircon age spectra. Gondwana Research 15, 228-242. 
Corcoran, P.L., 2012. Archaean sedimentary sequences of the Slave craton. Marine and Petroleum Geology 33(1), 80-91.

Corcoran, P.L., Mueller, W.U., 2004. Aggressive Archaean weathering, In: Eriksson, P.G., Altermann, W., Nelson, D.R., Mueller, W.U., Catuneanu, O. (Eds.), The Precambrian Earth: tempos and events. Developments in Precambrian Geology 12, Elsevier, Amsterdam, pp. 494-504.

Corcoran, P.L., Mueller, W.U., 2007. Time-transgressive Archean unconformities underlying molasse basin-fill successions of dissected oceanic arcs, Superior Province, Canada. Journal of Geology 115, 655-674.

Corcoran, P.L., Mueller, W.U., Chown, E.H, 1998. Climatic and tectonic influences on fan deltas and wave- to tide-controlled shoreface deposits: evidence from the Archean Keskarrah Formation, Slave Province, Canada. Sedimentary Geology 120, 125-152.

Corcoran, P.L., Mueller, W.U., Padgham, W.A., 1999. Influence of tectonism and climate on lithofacies distribution and sandstone composition in the Archean Beaulieu Rapids Formation, Northwest Territories, Canada. Precambrian Research 94, 175-204.

Crowell, J.C., 1999. Pre-Mesozoic Ice Ages: Their Bearing on Understanding the Climate System. Geological Society of America Memoir 192, 106p. 
Daily, B., Cooper, M.R., 1976. Clastic wedges and patterned ground in the Late Ordovician-Early Silurian tillites of South Africa. Sedimentology 23, 271-283.

Davies, N.L., Gibling, M.R., 2010a. Cambrian to Devonian evolution of alluvial systems: the sedimentological impact of the earliest land plants. Earth Science Reviews 98, 171200.

Davies, N.L., Gibling, M.R., 2010b. Paleozoic vegetation and the Siluro-Devonian rise of fluvial lateral accretion sets. Geology 38, 51-54.

Davies, N.L., Gibling, M.R., 2011. Evolution of fixed-channel alluvial plains in response to Carboniferous vegetation. Nature Geoscience 4 (9), 629-633.

Dawber, C., Tripati, A., 2011. Constraints on glaciation in the middle Eocene (46-37 Ma) from Ocean drilling Program (ODP) Site 1209 in the tropical Pacific Ocean. Paleoceanography 26, PA2208. Doi:10.1029/2010PA002037.

DeConto, R.M., Pollard, D., Wilson, P.A., Pälike, H., Lear, C., Pagani, M., 2008. Thresholds for Cenozoic bipolar glaciation. Nature 455, 652-656.

Des Marais, D.J., Strauss, H., Summons, R.E., Hayes, J.M., 1992. Carbon isotope evidence for the stepwise oxidation of the Proterozoic environment. Nature 359, 605609. 
Devaney, J.R., 2000. Regional geology of Sioux Lookout orogenic belt, western Wabigoon Subprovince: stages of volcanism, sedimentation, tectonism and mineralization. Ontario Geological Survey, Open File Report 6017, 158p.

De Wit, M.J., 1998. On Archean granites, greenstones, cratons and tectonics: does the evidence demand a verdict? Precambrian Research 91, 181-226.

De Wit, M.J., Hynes, A., 1995. The onset of interaction between the hydrosphere and oceanic crust, and the origin of the first continental lithosphere, In: Coward, M.P., Ries, A.C. (Eds.), Early Precambrian Processes. Geological Society, London Special Publication 95, pp. 1-9.

De Wit, M.J., Roering, C., Hart, R.J., Armstrong, R.A., De Ronde, R.E.J., Green,R.W.E., Tredoux, M., Perberdy, E., Hart, R.A., 1992. Formation of an Archaean continent. Nature $357,553-562$.

Deynoux, M., 1982. Periglacial polygonal structures and sand wedges in the Late Precambrian glacial formations of the Taoudeni Basin in Adrar of Mauretania (West Africa). Palaeogeography, Palaeoclimatology, Palaeoecology 39, 55-70. 
Dickey, J.O., Bender, P.L., Faller, J.E., Newhall, X.X., Ricklefs, R.L., Ries, J.G., Shelus, P.J., Veillet, C., Whipple, A.L., Wiant, J.R., Williams, J.G., Yoder, C.F., 1994. Lunar laser ranging: a continuing legacy of the Apollo program. Science 265, 482-490.

Domack, E.W., Hoffman, P.F., 2011. An ice grounding-line wedge from the Ghaub glaciation (635 Ma) on the distal foreslope of the Otavi carbonate platform, Namibia, and its bearing on the snowball Earth hypothesis. Geological Society of America Bulletin $123,1448-1477$.

Donaldson, J.A., de Kemp, E.A., 1998. Archean quartz arenites in the Canadian Shield: examples from the superior and Churchill Provinces. Sedimentary Geology 120, 153-176.

Dott, R.H., Jr., 2003. The importance of eolian abrasion in supermature quartz sandstones and the paradox of weathering on vegetation-free landscapes. Journal of Geology 111, $387-405$.

Driese, S.G., Jirsa, M.A., Ren, M., Brantley, S.L., Sheldon, N.D., Parker, D., Schmitz, M., 2011. Neoarchean paleoweathering of tonalite and metabasalt: implications for reconstructions of $2.69 \mathrm{Ga}$ early terrestrial ecosystems and paleoatmospheric chemistry. Precambrian Research 189, 1-17.

Droser, M.L., Bottjer, D.J., 1988. Trends in depth and extent of bioturbation in Cambrian carbonate marine environments, western United States. Geology 16, 233-236. 
Els, B.G., 1990. Determination of some palaeohydraulic parameters for a fluvial Witwatersrand succession. South African Journal of Geology 93 (3), 531-537.

Els, B.G., 1998a. The auriferous late Archaean sedimentation systems of South Africa: unique palaeo-environmental conditions? Sedimentary Geology 120, 205-224.

Els, B.G., 1998b. The question of alluvial fans in the auriferous Archean and Proterozoic successions of South Africa. South African Journal of Geology 101, 17-25.

Els, B.G., Mayer, J.J., 1992.Transgressive and progradational beach and nearshore facies in the Late Archaean Turffontein Subgroup of the Witwatersrand Supergroup, Vredefort area, South Africa. South African Journal of Geology 95, 60-73.

Els, B.G., Mayer, J.J., 1998. Coarse clastic tidal and fluvial sedimentation during a large sea-level rise: the Turffontein Subgroup in the Vredefort Structure, South Africa, In: Alexander, C.R., Davis, R.A., Henry, V.J. (Eds.), Tidalites; processes and products. Society for Economic Paleontology and Mineralogy (Society for Sedimentary Geology) Special Publication 61, pp. 155-165.

England, G.L., Rasmussen, B., Krapez, B., Groves, D.I., 2002. Paleoenvironmental significance of rounded pyrite in siliciclastic sequences of the Late Archean 
Witwatersrand Basin: oxygen deficient atmosphere or hydrothermal alteration? Sedimentology 49, 1133-1156.

Erba, E., 2006. The first 150 million years history of calcareous nannoplankton: Biosphere-geosphere interactions. Palaeogeography, Palaeoclimatology, Palaeoecology $232,237-250$.

Eriksson, K.A., 1977. Tidal deposits from the Archaean Moodies Group, Barberton Mountain Land, South Africa. Sedimentary Geology 18, 257-281.

Eriksson, K.A., 1979. Marginal marine depositional processes from the Archaean Moodies Group, Barberton Mountain Land, South Africa: evidence and significance. Precambrian Research 8, 153-182.

Eriksson, K.A., 1983. Archean iron-formations: environments of deposition and controls on formation. Journal of the Geological Society of Australia 30, 473-482.

Eriksson, K.A., Simpson, E.L., 1998. Controls on spatial and temporal distribution of Precambrian eolianites. Sedimentary Geology 120, 275-294.

Eriksson, K.A., Simpson, E.L., 2000. Quantifying the oldest tidal record: the $3.2 \mathrm{Ga}$ Moodies Group, Barberton greenstone Belt, South Africa. Geology 28, 831-834. 
Eriksson, K.A., Soegaard, K., 1985. Petrography and geochemistry of Precambrian sediments: implications for weathering and crustal evolution. Geological Survey of Finland Bulletin 331, 7-32.

Eriksson, K.A., Wilde, S.A., 2010. Paleoenvironmental analysis of Archean siliciclastic sedimentary rocks in the west-central Jack Hills belt, Western Australia with new constraints on ages and correlations. Journal of the Geological Society, London 167, 827840.

Eriksson, K.A., Krapez, B., Fralick, P.W., 1994. Sedimentology of greenstone belts: Signature of tectonic evolution. Earth Science Reviews 37, 1-88.

Eriksson, K.A., Krapez, B., Fralick, P.W., 1997. Sedimentological aspects of greenstone belts, In: De Wit, M.J., Ashwal, L. (Eds.), Tectonic Evolution of Greenstone Belts. Oxford University Press, pp. 33-54.

Eriksson, P.G., 1991. A note on coarse-grained gravity-flow deposits within Proterozoic lacustrine sedimentary rocks, Transvaal Sequence, South Africa. Journal of African Earth Sciences 12, 549-553.

Eriksson, P.G., Catuneanu, O., 2004. A commentary on Precambrian plate tectonics, In: Eriksson, P.G., Altermann, W., Nelson, D.R., Mueller, W.U., Catuneanu, O. (Eds.), The 
Precambrian Earth: Tempos and Events. Developments in Precambrian Geology 12, Elsevier, Amsterdam, pp. 201-213.

Eriksson, P.G., Condie, K.C., 2012. Cratonic sedimentation regimes in the ca. 2450 2000 Ma period: relationship to a possible widespread magmatic slowdown on Earth? Gondwana Research, http://dx.doi.org/10.1016/j.gr.2012.08.005.

Eriksson, P.G., Condie, K.C., Tirsgaard, H., Mueller, W.U., Altermann, W., Miall, A.D., Aspler, L.B., Catuneanu, O., Chiarenzelli, J.R., 1998. Precambrian clastic sedimentation systems. Sedimentary Geology 120, 5-53.

Eriksson, P.G., Simpson, E.L., Eriksson, K.A., Bumby, A.J., Steyn, G.L., Sarkar, S., 2000. Muddy roll-up structures in clastic playa beds of the $1.8 \mathrm{Ga}$ Waterberg Group, South Africa. Palaios 15, 177-183.

Eriksson, P.G., Martins-Neto, M.A., Nelson, D.R., Aspler, L.B., Chiarenzelli, J.R., Catuneanu, O., Sarkar, S., Altermann, W., Rautenbach, C.J. deW., 2001. An introduction to Precambrian basins: their characteristics and genesis. Sedimentary Geology 141/142, $1-35$.

Eriksson, P.G., Altermann, W., Nelson, D.R., Mueller, W.U., Catuneanu, O. (Eds.), 2004a. The Precambrian Earth: Tempos and Events. Elsevier, Amsterdam, 941p. 
Eriksson, P.G., Bumby, A.J., Mostert, P., 2004b. Early Precambrian epeiric seas, In: Eriksson, P.G., Altermann, W., Nelson, D.R., Mueller, W.U., Catuneanu, O. (Eds.), The Precambrian Earth: Tempos and Events. Developments in Precambrian Geology 12, Elsevier, Amsterdam, pp. 657-660.

Eriksson, P.G., Catuneanu, O., Nelson, D.R., Popa, M., 2005a. Controls on Precambrian sea level change and sedimentary cyclicity. Sedimentary Geology 176, 43-65.

Eriksson, P.G., Catuneanu, O., Els, B.G., Bumby, A.J., van Rooy, J.L., Popa, M., $2005 b$. Kaapvaal craton: changing first-and second-order controls on sea level from c. 3.0 Ga to 2.0 Ga. Sedimentary Geology 176, 121-148.

Eriksson, P.G., Banerjee, S., Catuneanu, O., Sarkar, S., Bumby, A.J., Mtimkulu, M.N., 2007. Prime controls on Archaean-Palaeoproterozoic sedimentation: change over time. Gondwana Research 12, 550-559.

Eriksson, P.G., Long, D.G.F., Bumby, A.J., Eriksson, K.A., Simpson, E.L., Catuneanu, O., Claassen, M., Mtimkulu, M.N., Mudziri, K.T., Brümer, J.J., van der Neut, M., 2008a. Palaeohydrological data from the 2.0-1.8 Ga Waterberg Group, South Africa: Discussion of a possible unique Palaeoproterozoic fluvial style. South African Journal of Geology $111,183-206$. 
Eriksson, P.G., Bose, P.K., Catuneanu, O., Sarkar, S., Banerjee, S., 2008b. Precambrian clastic epeiric embayments: examples from South Africa and India, In: Pratt, B.R., Holmden, C. (Eds.), Dynamics of epeiric seas. Geological Association of Canada Special Paper 48, St. Johns, Newfoundland, pp. 119-136.

Eriksson, P.G., Banerjee, S., Nelson, D.R., Rigby, M.J., Catuneanu, O., Sarkar, S., Roberts, R.J., Ruban, D., Mtimkulu, M.N., Sunder Raju, P.V., 2009. A Kaapvaal craton debate: nucleus of an early small supercontinent or affected by an enhanced accretion event? Gondwana Research 15, 354-372.

Eriksson, P.G., Rigby, M.J., Bandopadhyay, P.C., Steenkamp, N.C., 2011a. The Kaapvaal Craton, South Africa: no evidence for a supercontinental affinity prior to 2.0 Ga? International Geology Review 53 (11-12), 1312-1330.

Eriksson, P.G., Lenhardt, N., Wright, D.T., Mazumder, R., Bumby, A.J., 2011b. Late Neoarchaean-Palaeoproterozoic supracrustal basin-fills of the Kaapvaal craton: Relevance of the supercontinent cycle, the "Great Oxidation Event" and "Snowball Earth"? Marine and Petroleum Geology 28, 1385-1401.

Erwin, D.H., 1993. The Great Paleozoic Crisis: Life and Death in the Permian. Columbia University Press, New York, 327p. 
Erwin, D.H., 2001. Lessons from the past: Biotic recoveries from mass extinctions. Proceedings of the National Academy of Sciences of the United States of America 98, $5399-5403$.

Erwin, D.H., Laflamme, M., Tweedt, S.M., Sperling, E.A., Pisani, D., Peterson, K.J., 2011. The Cambrian Conundrum: Early Divergence and later Ecological Success in the Early History of Animals. Science 334, 1091-1097.

Etienne, J.L., Allen, P.A., Rieu, R., Guerroué, E.Le., 2008. Neoproterozoic glaciated basins: a critical review of the Snowball Earth hypothesis by comparison with Phanerozoic glaciations, In: Hambrey, M. J., Christoffersen, P., Glasser, N. F., Hubbard, B. (Eds.), Glacial Sedimentary Processes and Products. Blackwell, Oxford, pp. 343-399.

Evans, D.A.D., 2007. Key paleomagnetic pole from the Woongarra/Weeli Wolli large igneous province, Pilbara Craton, Australia; a link between supercratons? Abstracts with Programs Geological Society of America 39 (6), 285.

Evans, D.A.D., Raub, T.D., 2011. Neoproterozoic glacial palaeolatitudes: a global update. Geological Society of London Memoir 36, 93-112.

Evans, D.A., Beukes, N.J., Kirschvink, J.L., 1997. Low-latitude glaciation in the Palaeoproterozoic era. Nature 386, 262-266. 
Eyles, N., 2008. Glacio-epochs and the supercontinent cycle after $\sim 3.0$ Ga: tectonic boundary conditions for glaciation. Palaeogeography, Palaeoclimatology, Palaeoecology $258,89-129$.

Fairbridge, R.W., 1957. The dolomite question, In: Leblanc, R.J., Breeding, J.G. (Eds.), Regional aspects of carbonate deposition - a symposium. Society of Economic Paleontologists and Mineralogists Special Publication 5, pp. 125-178.

Fielding, C.R., Frank, T.D., Isbell, J.L., 2008. The late Paleozoic ice age-A review of current understanding and synthesis of global climate patterns. Geological Society of America Special Paper 441, 343-354.

Finkelstein, D.B., Brasseli, S.C., Pratt, L.M., 2010. Microbial biosynthesis of wax esters during dessication: Adaption of colonization of the earliest terrestrial environments. Geology 38, 247-250.

Flament, N., Coltice, N., Rey, P.F., 2011. The evolution of the ${ }^{87} \mathrm{Sr} /{ }^{86} \mathrm{Sr}$ of marine carbonates does not constrain continental growth. Precambrian Research, in press, doi: 10.1016/j.precamres.2011.10.009.

Fleet, M., 1998. Detrital pyrite in Witwatersrand gold reefs: X-ray diffraction evidence and implications for atmospheric evolution. Terra Nova 10, 302-306. 
Frakes, L.A., Francis, J.E., 1988. A guide to Phanerozoic cold polar climates from highlatitude ice-rafting in the Cretaceous. Nature 339, 547-549.

Frakes, L.A., Alley, N.F., Deynoux, M., 1995. Early Cretaceous ice rafting and climate zonation in Australia. International Geology Review 37, 567-583.

Fralick, P., Carter, J.E., 2011. Neoarchean deep marine paleotemperature: evidence from turbidite successions. Precambrian Research 191, 78-84.

Fralick, P.W., Hollings, P., King, D., 2008. Stratigraphy, geochemistry and depositional environments of Mesoarchean sedimentary units in western Superior Province: Implications for generation of early crust, In: Condie, K.C., Pease, V., (Eds.), When Did Plate Tectonics Begin on Planet Earth? Geological Society of America Special Paper 440, pp. 77-96.

Friedman, G.M., Sanders, J.E., Kopaska-Merkel, D.C., 1992. Principles of Sedimentary Deposits. Macmillan, New York, 717p.

Frimmel, H.E., Groves, D.I., Kirk, J., Ruiz, J., Chesley, J., Minter, W.E.L., 2005. The formation and preservation of the Witwatersrand goldfields, the largest gold province in the world, In: Hedenquist, J.W., Thompson, J.F.H., Goldfarb, R.J., Richards, J.P. (Eds.), $100^{\text {th }}$ Anniversary Volume. Economic Geology 100, 769-797. 
Fryberger, S.G., Schenk, C.J., 1988. Pin stripe lamination: A distinctive feature of modern and ancient eolian sediments. Sedimentary Geology 55, 1-15.

Garrett, P., 1970. Phanerozoic stromatolites: Noncompetitive ecological restriction by grazing and burrowing animals. Science169, 171-173.

Germs, G.J.B., 1972. New shelly fossils from the Nama Group, South West Africa. American Journal of Science 272, 752-761.

Giggenbach, W.F., 1996. Chemical composition of volcanic gases, In: Scarpa, R., Tilling, R.I. (Eds.), Monitoring and mitigation of volcano hazards. Springer, Berlin, pp. 221-256.

Given, R.K., Wilkinson, B.H., 1987. Dolomite abundance and stratigraphic age; constraints on rates and mechanisms of Phanerozoic dolostone formation. Journal of Sedimentary Petrology 57, 1066-1078.

Godderis, Y., Veizer, J., 2004. Tectonic control of chemical and isotopic composition of ancient oceans: the impact of continental growth. American Journal of Science 300, 434461.

Gostin, V.A., McKirdy, D.M., Webster, L.J., Williams, G.E., 2010. Ediacaran ice-rafting and coeval asteroid impact, South Australia: insights into the terminal Proterozoic environment. Australian Journal of Earth Sciences 57, 859-869. 
Gradstein, F.M., Ogg, J.G., Smith, A.G., 2004. A Geologic Time Scale. Cambridge University Press, Cambridge, U.K., 589p.

Grotzinger, J.P., Kasting, J.F., 1993. New constraints of Precambrian ocean composition. Journal of Geology 101, 235-243.

Grotzinger, J.P., Knoll, A.H., 1995. Anomalous carbonate precipitates: is the Precambrian the key to the Permian? Palaios 10/6, 578-596.

Grotzinger, J.P., Knoll, A.H., 1999. Stromatolites: evolutionary mileposts or environmental dipsticks? Annual Reviews of Earth and Planetary Science 27, 313-358.

Grotzinger, J.P., Arvidson, R.E., Bell III, J.F., Calvin, W., Clark, B.C., Fike, D.A., Golombek, M., Greely, R., Haldemann, A., Herkenhoff, K.E., Jolliff, B.L., Knoll, A.H., Malin, M., McLennan, S.M., Parker, T., Soderlom, L., Sohl-Dickstein, J.N., Squyres, S.W., Tosca, N.J., Watters, W.A., 2005. Stratigraphy and sedimentology of a dry to wet eolian depositional system, Burns formation, Meridiani Planum, Mars. Earth and Planetary Science Letters 240, 11-72.

Guo, Q., Strauss, H., Kaufman, A.J., Schröder, S., Gutzmer, J., Wing, B., Baker, M.A., Bekker, A., Jin, Q., Kim, S.-T., Farquhar, J., 2009. Reconstructing Earth's surface oxidation across the Archean-Proterozoic transition. Geology 37, 399-402. 
Habicht, K.S., Gade, M., Thamdrup, B., Berg, P., Canfield, D.E., 2002. Calibration of sulfate levels in the Archean ocean. Science 298, 2372-2374.

Hagadorn, J.W., Bottjer, D.J., 1997. Wrinkle structures: Microbially mediated sedimentary structures common in subtidal siliciclastic settings at the ProterozoicPhanerozoic transition. Geology 25, 1047-1050.

Hagadorn, J.W., Bottjer, D.J., 1999. Restriction of a Late Neoproterozoic biotope: suspect microbial structures and trace fossils at the Vendian-Cambrian transition. Palaios $14,73-85$.

Hamilton, W.B., 1998. Archean magmatism and deformation were not products of plate tectonics. Precambrian Research 91, 143-179.

Harris, C.W., Eriksson, K.A., 1990. Allogenic controls on the evolution of storm to tidal shelf sequences in the Early Proterozoic Uncompahgre Group, southwest Colorado, U.S.A. Sedimentology 37, 189-213.

Hart, M.B., Oxford, M.J., Hudson, W., 2002. The early evolution and palaeobiogeography of Mesozoic planktonic foraminifera. Geological Society, London Special Publications 194, 115-125. 
Hartley, A.J., Weissmann, G.G., Nichols, G.J., Warwick, G.L., 2010. Large distributive fluvial systems; characteristics, distribution and controls on development. Journal of Sedimentary Research 80, 167-183.

Hasiuk, F.J., 2008. Response of the elemental chemistry of carbonate phases to secular change in ocean chemistry. PhD thesis (unpublished), University of Michigan.

Hawkesworth, C.J., Kemp, A.I.S., 2006. Evolution of the continental crust. Nature 443, $811-817$.

Hazen, R.M., Papineau, D., Bleeker, W., Downs, R.T., Ferry, J.M., McCoy, T.J., Sverjensky, D.A., Yang, H., 2008. Mineral evolution. American Mineralogist 93, 16931720.

Heaman, H.L., 1997. Global mafic magmatism at 2.45 Ga: Remnants of a large igneous province? Geology 25, 299-302.

Hebert, C.L., Kaufman, A.J., Penniston-Dorland, S.C., Martin, A.J., 2010. Radiometric and stratigraphic constraints on terminal Ediacaran (post-Gaskiers) glaciation and metazoan evolution. Precambrian Research 182, 402-412.

Herzberg, C., Gazel, E., 2009. Petrological evidence for secular cooling in mantle plumes. Nature 458, 619-622. 
Herzberg, C., Condie, K., Korenaga, J., 2010. Thermal history of the Earth and its petrological expression. Earth and Planetary Science Letters 292, 79-88.

Hessler, A.M., Lowe, D.R., 2006. Weathering and sediment generation in the Archean: An integrated study of the evolution of siliciclastic sedimentary rocks of the $3.2 \mathrm{Ga}$ Moodies Group, Barberton Greenstone Belt, South Africa. Precambrian Research 151, $185-210$.

Heubeck, C., Lowe, D.R., 1994. Depositional and tectonic setting of the Archean Moodies Group, Barberton Greenstone Belt, South Africa. Precambrian Research 68, 257-290.

Hoffman, P.F., 1989. Speculations on Laurentia's first gigayear (2.0 to $1.0 \mathrm{Ga}$ ). Geology $17,135-138$.

Hoffman, P.F., Schrag, D.P., 2002. The snowball Earth hypothesis: testing the limits of global change. Terra Nova 14, 129-155.

Hohmann-Marriott, M.F., Blankenship, R.E., 2011. Evolution of photosynthesis. Annual Review of Plant Biology 62, 515-548. 
Holland, H.D., 2002. Volcanic gases, black smokers, and the Great Oxidation Event.Geochimica et Cosmochimica Acta 66, 3811-3826.

Holland, H.D., 2006. The oxygenation of the atmosphere and oceans. Philosophical Transactions of the Royal Society B 361, 903-915.

Howell, J.A., Mountney, N.P., 1997. Climatic cyclicity and accommodation space in arid and semi-arid depositional systems: an example from the Rotliegend Group of the Southern North Sea, In: North, C.P., Prosser, J.D. (Eds.), Petroleum Geology of the Southern North Sea: Future Potential. Geological Society, London Special Publication 123, pp. 199-218.

Hunter, R.E., 1977. Basic types of stratification in small eolian dunes. Sedimentology 24, $361-387$.

Hunter, R.E., 1981. Stratification styles in eolian sandstones: some Pennsylvanian to Jurassic examples from the western interior USA, In: Etheridge, F.G., Flores, R.M. (Eds.), Recent and Ancient Nonmarine Depositional Environments: Models for Exploration. Society of Economic Paleontologists and Mineralologists Specical Publication 31, 315-329.

Jackson, M.J., Simpson, E.L., Eriksson, K.A., 1990. Facies and sequence stratigraphic analysis in an intracratonic, thermal-relaxation basin: the Early Proterozoic, Lower 
Quilalar Formation and Ballara Quartzite, Mount Isa Inlier, Australia. Sedimentology 37, $1053-1078$.

James, N.P., Kendall, A.C., Pufahl, P.K, 2010. Introduction to biological and chemical sedimentary facies models, In: James, N.P., Dalrymple, R.W. (Eds.), Facies Models $4^{\text {th }}$ Edition. Geological Association of Canada, St. John's, Newfoundland, pp. 323-340.

Jenkins, G.S., 1993. A general circulation model study of the effects of faster rotation rate, enhanced $\mathrm{CO}_{2}$ concentration, and reduced solar forcing: implications for the faint young Sun paradox. Journal of Geophysical Research 98, 20803-20811.

Jenkins, G.S., 2003. GCM greenhouse and high-obliquity solutions for early Proterozoic glaciation and middle Proterozoic warmth. Journal of Geophysical Research 108 (D3), 4118, doi:10.1029/2001JD001582.

Johnston, D.T., Wolfe-Simon, F., Pearson, A., Knoll, A.H., 2009. Anoxygenic photosynthesis modulated Proterozoic oxygen and sustained Earth's middle age. Proceedings of the National Academy of Sciences of the USA 106, 16925-16929.

Jones, A.P., Pickering, K.T., 2003. Evidence for aqueous fluid-sediment transport and erosional processes on Venus. Journal of the Geological Society, London 160, 319-327. 
Jutras, P.J., Quillan, R.S., Leforte, M.J., 2009. Evidence from Middle Ordovician paleosols for the predominance of alkaline groundwater at the dawn of land plant radiation. Geology 37, 91-94.

Karpeta, W.B., Els, B.G., 1999. The auriferous Late Archaean Central Rand Group of South Africa, sea-level control of sedimentation? Precambrian Research 97, 191-214.

Karte, J., 1983. Periglacial phenomena and their significance as climatic and edaphic indicators. GeoJournal 7, 329-340.

Kasting, J.F., Liu, S.C., Donahue, T.M., 1979. Oxygen levels in the prebiological atmosphere. Journal of Geophysical Research 84, 3097-3107.

Kennedy, M.J., Christie-Blick, N., Prave, A.R., 2001. Carbon isotopic composition of Neoproterozoic glacial carbonates as a test of paleoceanographic models for snowball Earth phenomena. Geology 29, 1135-1138.

Kirkland, C.L., Wingate, M.T.D., Tyler, I.M., 2010. Quartz sandstone, The Bench. Geochronology Record 886, Geological Survey of Western Australia 182105, 1-5.

Kirschvink, J. L., 1992. Late Proterozoic low-latitude global glaciation: The snowball Earth, In: Schopf, J.W., Klein, CA. (Eds.), The Proterozoic Biosphere: a multidisciplinary study. Cambridge University Press, Cambridge, U.K., pp. 51-52. 
Klein, C., 2005. Some Precambrian banded iron-formations (BIFs) from around the world: their age, geologic setting, mineralogy, metamorphism, geochemistry, and origin. American Mineralogist 90, 1473-1499.

Knauth, L.P., 2005. Temperature and salinity history of the Precambrian ocean: implications for the course of microbial evolution. Palaeogeography, Palaeoclimatology, Palaeoecology 219, 53-69.

Knoll, A.H., 2011. The Multiple Origins of Complex Multicellularity. Annual Reviews of Earth and Planetary Sciences 39, 217-239.

Knoll, A.H., Bambach, R.K., Canfield, D.E., Grotzinger, J.P., 1996. Comparative Earth history and Late Permian mass extinction. Science 273, 452-457.

Kocurek, G., 1991. Interpretation of ancient eolian sand dunes. Annual Reviews Earth and Planetary Science 19, 43-75.

Kocurek, G., 1996. Desert aeolian systems, In: Reading, H. (Ed.), Sedimentary Environments: Processes, facies and stratigraphy. Blackwell Science, Oxford, pp. 125153. 
Kocurek, G., 1999. The aeolian rock record, In: Goudie, A., Livingstone, I. (Eds.), Aeolian environments, sediments and landforms. John Wiley and Sons, New York, pp. 239-259.

Kocurek, G., Dott, R.H., Jr., 1981. Distinction and uses of stratification type in the interpretation of eolian sand. Journal of SedimentaryResearch 51, 579-595.

Kocurek, G., Ewing, R.C., 2005. Aeolian dune field self-organization - implications for the formation of simple versus complex dune-field patterns. Geomorphology 72, 94-105.

Konhauser, K.O., Pecoits, E., Lalonde, S.V., Papineau, D., Nisbet, E.G., Barley, M.E., Arndt, N.T., Zahnle, K., Kamber, B.S., 2009. Oceanic nickel depletion and a methanogen famine before the Great Oxidation Event. Nature 458, 750-753.

Korenaga, J., 2006. Archean geodynamics and the thermal evolution of the Earth, In: Benn, K., Mareschal, J.-C., Condie, K. (Eds.), Archean Geodynamics and Environments. American Geophysical Union Geophysical Monograph Series 164, AGU, Washington DC, pp. 7-32.

Korenaga, J., 2008. Urey ratio and the structure and evolution of Earth's mantle. Reviews of Geophysics 46, RG2007, doi: 10.1029/2007RG000241. 
Krapez, B., 1984. Sedimentation in a small, fault-bounded basin; the LallaRookh Sandstone, East Pilbara Block. Geology Department and Extension Service Publication, University of Western Australia 9.

Krapez, B., 1996. Sequence stratigraphic concepts applied to the identification of basinfilling rhythms in Precambrian successions. Australian Journal of Earth Sciences 43, 355380.

Krapez, B., Barley, M.E., 1987. Archaean strike-slip faulting and related ensialic basins: evidence from the Pilbara Block, Australia. Geological Magazine 124, 555-567.

Kuhn, W.R., Walker, J.C.G., Marshall, H.G., 1989. The effect on Earth's surface temperature from variations in rotation rate, continent formation, solar luminosity, and carbon dioxide. Journal of Geophysical Research 94, 11129-11136.

Kump, L.R., 2008. The role of seafloor hydrothermal systems in the evolution of seawater composition during the Phanerozoic, In: Magma to microbe: modelling hydrothermal processes at ocean spreading centers. Geophysical Monograph Series 178, 275-283.

Kump, L.R., Kasting, J.F., Barley, M.E., 2001. Rise of oxygen and the "upside-down" Archean mantle. Geochemistry, Geophysics, Geosystems 2, 1025-1035. 
Kusky, T.M., Kidd, W.S.F., 1992. Remnants of an Archean oceanic plateau, Belingwe Greenstone Belt, Zimbabwe. Geology 20, 43-46.

Lambeck, K., 1980. The Earth's Variable Rotation: Geophysical Causes and Consequences. Cambridge University Press, Cambridge, U.K., 449p.

Lancaster, N., 1997. Response of eolian geomorphic systems to minor climate changes: examples from the southern Californian deserts. Geomorphology 19, 333-347.

Landing, E., MacGabhann, B.A., 2010. First evidence for Cambrian glaciation provided by sections in Avalonian New Brunswick and Ireland: Additional data for AvalonGondwana separation by the earliest Palaeozoic. Palaeogeography, Palaeoclimatology, Palaeoecology 285, 174-185.

Lazarus, D.B., Kotrc, B., Wulf, G., Schmidt, D.N., 2009. Radiolarians decreased silicification as an evolutionary response to reduced Cenozoic ocean silica availability. Proceedings of the National Academy of Sciences of the USA 106, 9333-9338.

Lee, C.-T.A., Luffi, P., Chin, E., 2011. Building and destroying continental mantle. Annual Review of Earth and Planetary Sciences 39, 59-90. 
Lenardic, A., Moresi, L.-N., Jellinek, A.M., Manga, M., 2005. Continental insulation, mantle cooling, and the surface area of oceans and continents. Earth and Planetary Science Letters 234, 317-333.

Levorsen, A. I., 1943. Discovery thinking. American Association of Petroleum Geologists Bulletin 27, 887-928.

Lindsey, K.A., Gaylord, D.R., 1992. Fluvial, coastal, nearshore and shelf deposition in the Upper Proterozoic (?) to Lower Cambrian Addy Quartzite, northeastern Washington. Sedimentary Geology 77, 15-35.

Long, D.G.F., 2011. Architecture and depositional style of fluvial systems before land plants: a comparison of Precambrian, early Paleozoic, and Modern fluvial systems, In: Davidson, S.K., Leleu, S., North, C.P. (Eds.), From River to Rock Record: The preservation of fluvial sediments and their subsequent interpretation. Society of Economic Paleontologists and Mineralogists Special Publication 97, pp. 37-61.

Loope, D.B., Rowe, C.M., Joekel, R.M., 2001. Annual monsoon rains recorded in Jurassic dunes. Nature 412, 64-66.

Lowe, D.R., 1983. Restricted shallow-water sedimentation of Early Archean stromatolitic and evaporitic strata of the Strelley pool Chert, Pilbara Block, Australia. Precambrian Research 19, 239-283. 
Machel, H.G., 2004. Concepts and models of dolomitization; a critical reappraisal, In: Braithwaite, C.J.R., Giancarlo, R., Darke, G. (Eds.), The geometry and petrogenesis of dolomite hydrocarbon reservoirs. Geological Society, London Special Publication 235, pp. 7-63.

Mackenzie, F.T., Pigott, J.D., 1981. Tectonic controls of Phanerozoic sedimentary rock cycling. Journal of the Geological Society, London 138, 183-196.

Malenda, H.F., Simpson, E.L., Wizevich, M.C., Tindall, S.E., 2012. Towards the recognition of biological soil crusts in the rock record: Key features from the study of modern and Cretaceous examples, In: Noffke, N., Chafetz, H. (Eds.), Microbial Mats in Sandy Deposits (Archean to Today). Society of Sedimentary Geology Special Publication, in press.

Maliva R., Knoll, A.H., Siever, R., 1989. Secular change in chert distribution: a reflection of evolving biological participation in the silica cycle. Palaios 4, 519-532.

Maliva, R.G., Knoll, A.H., Simonson, B.M., 2005. Secular change in the Precambrian silica cycle: insights from chert petrology. Geological Society of America Bulletin 117, $835-845$. 
Maloof, A.C., Porter, S.M., Moore, J.L., Dudás, F.Ö., Bowring, S.A., Higgins, J.A., Fike, D.A., Eddy, M.P., 2010. The earliest Cambrian record of animals and ocean geochemical change. Geological Society of America Bulletin 122, 1731-1774.

Martin, D. McB., 1999. Depositional setting and implications of Paleoproterozoic glaciomarine sedimentation in the Hamersley Province, Western Australia. Geological Society of America Bulletin 111, 189-203.

Martins-Neto, M., 1996. Lacustrine fan-deltaic sedimentation in a Proterozoic rift basin; the Sopa-Brumadinho tectonosequence, southeastern Brazil.Sedimentary Geology 106, 65-95.

Martins-Neto, M.A., Costa, N.B.O.R., 1985. Geologia da borda oeste da Serra do Caraça. Trabalho Geológico, IGC/UFMG, inédito.

McElhinny, M., 2004. Geocentric axial dipole hypothesis: a least squares perspective. American Geophysical Union Geophysical Monograph 145, 1-12.

McIlroy, D., Logan, G.A., 1999. The impact of bioturbation on infaunal ecology and evolution during the Proterozoic-Cambrian transition.Palaios 14, 58-72.

Miall, A. D., 1995. Whither stratigraphy? Sedimentary Geology 100, 5-20. 
Miall, A. D., 1996. The geology of fluvial deposits: sedimentary facies, basin analysis and petroleum geology. Springer-Verlag, Heidelberg, 582p.

Miall, A. D., 2010. The geology of stratigraphic sequences, Second edition. SpringerVerlag, Berlin, 522p.

Miall, A. D., in press. A new uniformitarianism: stratigraphy as just a set of "frozen accidents", In: Smith, D. G., Bailey, R., J., Burgess, P., Fraser, A. (Eds.) Strata and time. Gelogical Society, London Special Publication.

Migdisov, A.A., Bredanova, N.V., Rozen, O.M., Abbyasov, A.A., 2003. Evolution of the mineral composition of pelitic and psammitic rocks in the geologic history of continents. Geochemistry International 41, 959-978.

Milliman, J.D., 1993. Production and accumulation of calcium carbonate in the ocean: budget of a nonsteady state. Global Biogeochemical Cycles 7, 927-957.

Minter, W.E.L., 1976. Detrital gold, uranium and pyrite concentrations related to sedimentology of the Vaal Reef placer, Witwatersrand, South Africa. Economic Geology $71,157-176$.

Minter, W.E.L., 1999. Irrefutable detrital origin of Whitwatersrand gold and evidence of aeolian signatures. Economic Geology 94/5, 665-670. 
Minter, W.E.L., 2006. The sedimentary setting of Witwatersrand placer mineral deposits in the Archean atmosphere, In: Keslerm S.E., Ohmoto, H. (Eds.), Evolution of Early Earth's Atmosphere, Hydrosphere, and Biosphere - Constraints from Ore Deposits. Geological Society of America Memoir 198, pp. 105-119.

Mints, M.V., 2007. Paleoproterozoic Supercontinent: origin and evolution of accretionary and collisional orogens exemplified in northern cratons. Geotectonics 41(4), 257-280.

Mints, M.V., this volume. The secular changes in the relationships and interaction of the plate-tectonics and mantle plume caused processes in the Precambrian of the East European and North American cratons. Gondwana Research.

Mints, M.V., Konilov, A.N., 2004. Geodynamic crustal evolution and long-lived supercontinents during the Palaeoproterozoic: evidence from granulite-gneiss belts, collisional and accretionary orogens, In: Eriksson, P.G., Altermann, W., Nelson, D.R., Mueller, W.U., Catuneanu, O. (Eds.), The Precambrian Earth: Tempos and events. Developments in Precambrian Geology 12, Elsevier, Amsterdam, pp. 223-239.

Mints, M.V., Kaulina, T.V., Konilov, A.N., Krotov, A.V., Stupak, V.M., 2007. The thermal and geodynamic evolution of the Lapland granulite belt: implications for the thermal structure of the lower crust during granulite-facies metamorphism. Gondwana Research 12, 25-267. 
Montenat, C., Barrier, P., d'Estevou, P.O., Hibsch, C., 2007. Seismites: An attempt at critical analysis and classification. Sedimentary Geology 196, 5-30.

Moore, J.M., Polteau, S., Armstrong, R.A., Corfu, F., Tsikos, H., 2012. The age and correlation of the Postmasburg Group, southern Africa: Constraints from detrital zircon grains. Journal of African Earth Sciences 64, 9-19.

Morrow, D.W., Abercrombie, H.J., 1994. Rates of Dolomitization: The Influence of Dissolved Sulphate, In: Purser, B., Tucker, M., Zenger, D. (Eds.), Dolomites: A Volume in Honour of Dolomieu. International Association of Sedimentologists Special Publication 21, pp. 377-386.

Morrow, D.W., Ricketts, B.D., 1988. Experimental investigation of sulfate inhibition of dolomite and its mineral analogues: sedimentology and geochemistry of dolostones, based on a symposium. Society of Economic Paleontologists and Mineralogists Special Publication 43, 25-38.

Mossman, D.J., Minter, W.E.L., Dutkiewicz, A., Hallbauer, D.K., George, S.C., 2008. The indigenous origin of Witwatersrand “carbon”. Precambrian Research 164, 173-186. 
Mountney, N.P., 2006. Eolian facies models, In: Posamentier, H.W., Walker, R.G. (Eds.), Facies models revisited. Society of Economic Paleontologists and Mineralogists Special Publication 84, pp. 19-83.

Mueller, W. U., Corcoran, P. L., 1998. Late-orogenic basins in the Archean Superior Province, Canada: characteristics and inferences. Sedimentary Geology 120, 177-203.

Mueller, W.U., Corcoran, P.L., 2001. Volcanic and sedimentary processes operating on a marginal continental arc: evidence from the Archean Raquette Lake Formation, Slave Province, Canada. Sedimentary Geology 141-142, 169-204.

Mueller, W.U., Donaldson, J.A., Doucet, P., 1994. Volcanic and tectono-plutonic influences on sedimentation in the Archaean Kirkland Basin, Abitibi greenstone belt, Canada. Precambrian Research 68, 201-230.

Mueller, W.U., Corcoran, P.L., Pickett, C., 2005. Mesoarchean continental breakup: evolution and inferences from the $>2.8 \mathrm{Ga}$ Slave craton-cover succession, Canada. Journal of Geology 113, 23-45.

Mustard, P.S., Donaldson, J.A., 1987. Early Proterozoic ice-proximal glaciomarine deposition: The lower Gowganda Formation at Cobalt, Ontario, Canada. Geological Society of America Bulletin 98, 373-387. 
Nelson, G.J., Pufahl, P.K., Hiatt, E.E., 2010. Paleoceanographic constraints on Precambrian phosphorite accumulation, Baraga Group, Michigan, USA. Sedimentary Geology 226, 9-21.

Nio, S. D., Yang, C. S., 1991. Sea-level fluctuations and the geometric variability of tidedominated sandbodies. Sedimentary Geology 70, 161-193.

Nisbet, E.G., Grassineau, N.W., Howe, C.J., Abell, P.I., Regelous, M., Nisbet, R.E.R., 2007. The age of Rubisco: The evolution of oxygenic photosynthesis. Geobiology 5(4), 311-335.

Noffke, N., 2010. Geobiology: Microbial Mats in Sandy Deposits from the Archean era to Today. Springer-Verlag, Berlin, 194p.

Och, L.M., Shields-Zhou, G.A., 2012. The Neoproterozoic oxygenation event: environmental perturbations and biogeochemical cycling. Earth Science Reviews 110, 26-57.

Ojakangas, R.W., 1985. Review of Archean clastic sedimentation, Canadian Shield: major felsic volcanic contributions to turbidite and alluvial fan-fluvial facies associations, In: Ayres, L.D.,Thurston, P.C., Card, K.D., Weber, W. (Eds.), Evolution of Archean supracrustal sequences. Geological Association of Canada Special Paper 28, pp. 23-47. 
Ojakangas, R.W., Marmo, J.S., Heiskanen, K.I., 2001. Basin evolution of the Paleoproterozoic Karelian Supergroup of the Fennoscandian (Baltic) Shield. Sedimentary Geology 141-142, 255-285.

Page, R.W., Sun, S.S., 1994. Evolution of the Kimberley region, Western Australia and adjacent Proterozoic inliers - new geochronological constraints. Geological Society of Australia Abstracts 37, 332-333.

Papineau, D., 2010. Global biogeochemical changes at both ends of the Proterozoic: insights from phosphorites. Astrobiology 10, 165-181.

Payne, J.L., Clapham, M.E., 2012. End-Permian Mass Extinction in the Oceans: An Ancient Analog for the Twenty-First Century? Annual Review of Earth and Planetary Sciences 40, 89-111.

Payne, J.L., Lehrmann, D.J., Follett, D., Seibel, M., Kump, L.R., Riccardi, A., Altiner, D., Sano, H., Wei, J., 2007. Erosional truncation of uppermost Permian shallow-marine carbonates and implications for Permian-Triassic boundary events. Bulletin of the Geological Society of America 119/7-8, 771-784.

Pisarevsky, S.A., McCausland, P.J.A., Hodych, J.P., O’Brien, S.J., Tait, J.A., Murphy, J.B., 2012. Paleomagnetic study of the late Neoproterozoic Bull Arm and Crown Hill 
formations (Musgravetown Group) of eastern Newfoundland: implications for Avalonia and West Gondwana paleogeography. Canadian Journal of Earth Sciences 49, 308-327.

Plotnick, R. E., 1986. A fractal model for the distribution of stratigraphic hiatuses. Journal of Geology 94, 885-890.

Plotnick, R.E., Dornbos, S.Q., Chen, J.Y., 2010. Information landscapes and the sensory ecology of the Cambrian radiation. Paleobiology 36, 303-17.

Porter, S.M., Knoll, A.H., 2000. Testate amoebae in the Neoproterozoic Era: Evidence from vase-shaped microfossils in the Chuar Group, Grand Canyon. Paleobiology 26, $360-385$.

Poulton, S.W., Fralick, P.W., Canfield, D.E., 2004. The transition to a sulphidic ocean approximately 1.84 billion years ago. Nature 431, 173-177.

Poulton, S.W., Fralick, P.W., Canfield, D.E., 2010. Spatial variability in oceanic redox structure 1.8 billion years ago. Nature Geoscience 3(7), 486-490.

Pratt, B.R., Holmden, C. (Eds.), 2008. Dynamics of Epeiric Seas. Geological Association of Canada Special Publication 48, St. John's, Newfoundland, 406p. 
Pratt, B.R., James, N.P., 1986. The St. George Group (Lower Ordovician) of western Newfoundland: Tidal flat island model for carbonate sedimentation in shallow epeiric seas. Sedimentology 33, 313-343.

Prave, A.R., 2002. Life on land in the Proterozoic: Evidence from the Torridonian rocks of northwest Scotland. Geology 30, 811-814.

Preiss, W.V., Ashley, P.M., Williams, G.E., Schmidt, P.W., Gostin, V.A., McKirdy, D.M., 2011. The glacial succession of Sturtian age in South Australia - the Yudnamutana Subgroup. Geological Society of London Memoir 36, 701-712.

Pruss, S.B., Fraiser, M.L., D. J. Bottjer, 2004. The proliferation of Early Triassic wrinkle structures: Implications for environmental stress following the end-Permian mass extinction. Geology 32, 461-464.

Pruss, S.B., Finnegan, S., Fischer, W.W., Knoll, A.H., 2010. Carbonates in skeleton-poor seas: New insights from Cambrian and Ordovician strata of Laurentia. Palaios 25, 73-84.

Pufahl, P.K., 2010. Bioelemental sediments, In: James, N.P., Dalrymple, R.W. (Eds.), Facies Models, $4^{\text {th }}$ Edition. Geological Association of Canada, St. John's, Newfoundland, pp. $477-503$. 
Pufahl, P.K., Hiatt, E.E., 2012. Oxygenation of the Earth's atmosphere-ocean system: a review of physical and chemical sedimentologic responses. Marine and Petroleum Geology 32, 1-20.

Rautenbach, C.J.deW., 2001. A hypothetical approach to determining the effect of palaeorotational rates on Earth's Neoproterozoic palaeoclimate. Journal of African Earth Sciences 33, 463-473.

Reading, H.G., (Ed.), 1978. Sedimentary Environments and Facies. Blackwell, Oxford, $557 \mathrm{p}$.

Retallack, G.J., 2008. Cambrian paleosols and landscapes of South Australia. Australian Journal of Earth Sciences 55, 1083-1106.

Robb, L.J., Meyer, F.M., 1995a. The Witwatersrand Basin, South Africa: Geological framework and mineralization processes. Ore Geology Reviews 10, 67-94.

Robb, L.J., Meyer, F.M., 1995b. The Witwatersrand Basin, South Africa: geological framework and mineralization processes. Economic Geology Research Unit Information Circular 293, University of Witwatersrand, Johannesburg, South Africa, 37p.

Rogers, J.J.W., 1996. A history of continents in the past three billion years. Journal of Geology 104, 91-107. 
Ronov, A.B., 1964.Common tendencies in the chemical evolutions of the Earth's crust, ocean and atmosphere. Geochemistry International 4, 713-737.

Roy, S., 1997. Genetic diversity of manganese deposition in the terrestrial geological record, In: Nicholson, K., Hein, J.R., Bühn, B., Dasgupta, S. (Eds.), Manganese mineralization: geochemistry and mineralogy of terrestrial and marine deposits. Geological Society, London Special Publication 119, pp. 5-27.

Sadler, P. M., 1981. Sedimentation rates and the completeness of stratigraphic sections. Journal of Geology 89, 569-584.

Saito, M.A., 2009. Less nickel for more oxygen. Nature 458, 714-715.

Sakurai, R., Ito, M., Ueno, Y., Kitajima. K., Maruyama, S., 2005. Facies architecture and sequence-stratigraphic features of the Tumbiana Formation in the Pilbara Craton, northwestern Australia: implications for depositional environments of oxygenic stromatolites during the Late Archean. Precambrian Research 138, 255-273.

Sandberg, P.A., 1983. An oscillating trend in Phanerozoic non-skeletal carbonate mineralogy. Nature 305, 19-22. 
Sansjofre, P., Ader, M., Trindade, R.I.F., Elie, M., Lyons, J., Cartigny, P., Nogueira, A.C.R., 2011. A carbon isotope challenge to the snowball Earth. Nature 478, 93-96.

Santosh, M., Maruyama, S., Yamamoto, S., 2009. The making and breaking of supercontinents: Some speculations based on superplumes, super downwelling and the role of tectosphere. Gondwana Research 15, 324-341.

Sarkar, S., Chakraborty, S., Banerjee, S., Bose, P.K., 2002. Facies sequence and cryptic imprint of sag tectonics in late Proterozoic Sirbu Shale, central India, In: Altermann, W., Corcoran, P. (Eds.), Precambrian Sedimentary Environments: A Modern Approach to Ancient Depositional Systems. International Association of Sedimentologists Special Publication 33, Blackwell, Oxford, pp. 369-382.

Sarkar, S., Eriksson, P.G., Chakraborty, S., 2004. Epeiric sea formation on Neoproterozoic supercontinent break-up: a distinctive signature in coastal storm bed amalgamation. Gondwana Research 7, 313-322.

Sarkar, S., Banerjee, S., Eriksson, P.G., Catuneanu, O., 2005. Microbial mat control on siliciclastic Precambrian sequence stratigraphic architecture: Examples from India. Sedimentary Geology 176, 195-209. 
Sarkar, S., Bose, P.K., Samanta, P., Sengupta, P., Eriksson, P.G., 2008. Microbial mat mediated structures in the Ediacaran Sonia Sandstone, Rajasthan, India, and their implications for Proterozoic sedimentation. Precambrian Research 162, 248-263.

Scherer, C.M.S., Lavina, E. L. C., 2005. Sedimentary cycles and facies architecture of aeolian-fluvial strata of the Upper Jurassic Guara Formation, southern Brazil. Sedimentology 52, 1323-1341.

Schieber, J., 1989. Facies and origin of shales from the mid-Proterozoic Newland Formation, Belt Basin, Montana, U.S.A. Sedimentology 36, 203-219.

Schieber, J., 1998. Possible indicators of microbial mat deposits in shales and sandstones: examples from the mid-Proterozoic Belt Supergroup, Montana, USA. Sedimentary Geology 120, 105-124.

Schieber, J., Bose, P.K., Eriksson, P.G., Banerjee, S., Sarkar, S., Altermann, W., Catuneanu, O. (Eds.), 2007. Atlas of Microbial Mat features preserved within the Siliciclastic Rock Record. Atlases in Geoscience 2, Elsevier, Amsterdam, 311p.

Schlager, W., 2004. Fractal nature of stratigraphic sequences. Geology 32, 185-188.

Schmidt, P.W., 2001. Palaeomagnetic evidence for low-latitude glaciation: the geocentric axial dipole hypothesis for the Proterozoic?, In: Sircombe, K.N., Li, Z.X. (Eds.), From 
Basins to Mountains: Rodinia at the Turn of the Century. Geological Society of Australia Abstracts 65, 95-98.

Schmidt, P.W., Williams, G.E., 1995. The Neoproterozoic climatic paradox: equatorial palaeolatitude for Marinoan glaciation near sea level in South Australia. Earth and Planetary Science Letters 134, 107-124.

Schmidt, P.W., Williams, G.E., 1999. Paleomagnetism of the Paleoproterozoic hematitic breccia and paleosol at Ville-Marie, Québec: further evidence for the low paleolatitude of Huronian glaciation. Earth and Planetary Science Letters 172, 273-285.

Schmidt, P.W., Williams, G.E., 2008. Palaeomagnetism of red beds from the Kimberley Group, Western Australia: implications for the palaeogeography of the $1.8 \mathrm{Ga}$ King Leopold glaciation. Precambrian Research 167, 267-280.

Schmidt, P.W., Williams, G.E., Embleton, B.J.J., 1991. Low palaeolatitude of Late Proterozoic glaciation: early timing of remanence in haematite of the Elatina Formation, South Australia. Earth and Planetary Science Letters 105, 355-367.

Schmidt, P.W., Williams, G.E., McWilliams, M.O., 2009. Palaeomagnetism and magnetic anisotropy of late Neoproterozoic strata, South Australia: Implications for the palaeolatitude of late Cryogenian glaciation, cap carbonate and the Ediacaran System. Precambrian Research 174, 34-52. 
Schoenberg, R., Kamber, B.S., Collerson, K.D., Moorbath, S., 2002. Tungsten isotope evidence from 3.8-Gyr metamorphosed sediments for early meteorite bombardment of the Earth. Nature 418, 403-405.

Schopf, J. W., 1999. Cradle of Life. Princeton University Press, New Jersey, 367p.

Schopf, J.W., 2006. Fossil evidence of Archaean life. Philosophical Transactions of the Royal Society B 361, 869-885.

Schumm, S.A., 1961. Speculations concerning paleohydrologic control of terrestrial sedimentation. Geological Society of America Bulletin 79, 1573-1588.

Schwab, F.L., 1978. Secular trends in the composition of sedimentary rock assemblages Archean through Phanerozoic time. Geology 6, 532-536.

Seilacher, A., 1999. Biomat-related lifestyles in the Precambrian. Palaios14, 86-93.

Seilacher, A., Pflüger, F., 1994. From biomats to benthic agriculture: a biohistoric revolution, In: Krumbein, W.E., Paterson, D.M., Stal, L.J. (Eds.), Biostabilization of sediments. Bibliotheks und Informationssystem der Universitat Oldenburg, Oldenburg, pp. $97-105$. 
Shen, S.-Z., Crowley, J.L., Wang, Y., Bowring, S.A., Erwin, D.H., Sadler, P.M., Cao, C.Q., Rothman, D.H., Henderson, C.M., Ramezani, J., Zhang, H., Shen, Y., Wang, X.-D., Wang, W., Mu, L., Li, W.-Z., Tang, Y.-G., Liu, X.-L., Liu, L.-J., Zeng, Y., Jiang, Y.-F., Jin, Y.-G., 2011. Calibrating the end-Permian mass extinction. Science 334/6061, 13671372.

Shields, G.A., 2007. A normalised seawater strontium isotope curve: possible implications for Neoproterozoic-Cambrian weathering rates and the further oxygenation of the earth. eEarth 2, 35-42.

Simonson, B.M., Byerly, G.R., Lowe, D.R., 2004. The early Precambrian stratigraphic record of large extraterrestrial impacts, In: Eriksson, P.G., Altermann, W., Nelson, D.R., Mueller, W.U., Catuneanu, O. (Eds.), The Precambrian Earth: Tempos and Events. Developments in Precambrian Geology 12, Elsevier, Amsterdam, pp. 27-45.

Simpson, E.L., Eriksson, K.A., Eriksson, P.G., Bumby, A.J., 2002. Eolian dune degradation and generation of massive sandstones in the Paleoproterzoic Makgabeng Formation, Waterberg Supergroup, South Africa. Journal of Sedimentary Research 72, $40-45$.

Simpson, E. L., Eriksson, K. A. Kuklis, C. A., Eriksson, P. G., Bumby, A. J., van Jaarsveld, C. F. 2004a. Saline pan deposits from the approximately 1.8 Ga Makgabeng Formation, Waterberg Group, South Africa. Sedimentary Geology 163, 279-292. 
Simpson, E.L., Bose, P., Alkmim, F.F., Rainbird, R., Martins-Neto, M., Bumby, A., Eriksson, P.G., Eriksson, K.A., Middleton, L., 2004b. Oldest eolian deposits, earliest c. 1.8 Ga ergs and Proterozoic erg dynamics, In: Eriksson, P.G., Alterman, W., Nelson, D., Mueller, W., Catuneanu, O. (Eds.), The Precambrian Earth: Tempos and Events. Developments in Precambrian Geology 12, Elsevier, Amsterdam, pp. 642-657.

Simpson, E.L., Eriksson, K.A., Mueller, W., 2012. 3.2 Ga eolian deposits from the Moodies Group, Barberton Greenstone Belt, South Africa; Implications for the origin of first-cycle quartz sandstones. Precambrian Research, in press. Doi: 10.1016/j.precamres.2012.01.019.

Simpson, W.S., Simpson, E.L., Wizevich, M.C., Malenda, H.F., Hilbert-Wolf, H.L., Tindall, S.E., 2010. A preserved Late Cretaceous biological soil crust in the capping sandstone member, Wahweap Formation, Grand Staircase-Escalante National Monument, Utah, Palaeoclimatic implications. Sedimentary Geology 230, 139-145.

Skulski, T., Hynes, A., Percival, J., Craven, J., Sanborn-Barrie, M., Helmstaedt, H., 2004. Secular Changes in Tectonic Evolution and the Growth of Continental Lithosphere. Lithoprobe Celebratory Conference: From Parameters to Processes - Revealing the Evolution of a Continent. 12.10.-15.10., Toronto, Ontario, Canada.

(http://www.lithoprobe.ca/Contributed\%20Abstracts/Oral\%20Presentation/SkulskiSecularChange.pdf) 
Sloss, L. L., 1963. Sequences in the cratonic interior of North America. Geological Society of America Bulletin 74, 93-113.

Smirnov, A.V., Tarduno, J.A., 2004. Secular variation of the Late Archean-Early Proterozoic geodynamo. Geophysical Research Letters 31, L16607, doi:10.1029/2004GL020333.

Soegaard, K., Eriksson, K.A., 1985. Evidence of tide, storm, and wave interaction on a Precambrian siliciclastic shelf: the 1.700 M.Y. Ortega Group, New Mexico. Journal of Sedimentary Petrology 55, 672-684.

Soreghan, G.S., Soreghan, M.J., Poulsen, C.J., Young, R.A., Eble, C.F., Sweet, D.E., Davogustto, O.C., 2008. Anomalous cold in the Pangaean tropics. Geology 36, 659-662.

Srinivasan, R., Ojakangas, R.W., 1986. Sedimentology of quartz-pebble conglomerates and quartzites of the Archean Bababudan Group, Dharwar Craton, South India: evidence for early crustal stability. Journal of Geology 94, 199-214.

Stanley, S.M., Hardie, L.A., 1998. Secular oscillations in the carbonate mineralogy of reef-building and sediment-producing organisms driven by tectonically forced shifts in seawater chemistry. Palaeogeography, Palaeoclimatology, Palaeoecology 144, 3-19. 
Stern, R.J., 2008. Modern-style plate tectonics began in Neoproterozoic time: An alternative interpretation of Earth's tectonic history, In: Condie, K.C., Pease, V. (Eds.), When Did Plate Tectonics Begin on Planet Earth? Geological Society of America Special Paper 440, 265-280.

Stiff, B.J., Hansel, A.K., 2004. Quaternary glaciations in Illinois, In: Ehlers, J., Gibbard, P.L. (Eds.), Quaternary Glaciations Extent and Chronology, Part II: North America. Developments in Quaternary Science 2, Elsevier, Amsterdam, pp. 71-82.

Strik, G., de Wit, M.J., Langereis, C.G., 2007. Palaeomagnetism of the Neoarchaean Pongola and Ventersdorp Supergroups and an appraisal of the 3.0-1.9 Ga apparent polar wander path of the Kaapvaal Craton, Southern Africa. Precambrian Research 153, 96115.

Strömberg, C.A.E., 2011. Evolution of grasses and grassland ecosystems. Annual Review of Earth and Planetary Sciences 39, 517-44.

Sumner, D.Y., Grotzinger, J.P., 2004. Implications for Neoarchaean ocean chemistry from primary carbonate mineralogy of the Campbellrand-Malmani Platform, South Africa. Sedimentology 51, 1273-1299. 
Sweet, D.E., Soreghan, G.S., 2008. Polygonal cracking in coarse clastics records cold temperatures in the equatorial Fountain Formation (Pennsylvanian-Permian, Colorado). Palaeogeography, Palaeoclimatology, Palaeoecology 268, 193-204.

Sweet, K., Knoll, A.H., 1989. Marine pisolites from Upper Proterozoic carbonates of East Greenland and Spitsbergen. Sedimentology 36, 75-93.

Swett, K., Klein, G.deV., Smit, D.E., 1971. A Cambrian tidal sand body - the Eriboll Sandstone of Northwest Scotland: an ancient-recent analog. Journal of Geology 79, 400415.

Swezey, C., 2001. Eolian sediment transport to late Quaternary climate changes: temporal and spatial patterns in the Sahara. Palaeogeography, Palaeoclimatology, Palaeoecology $167,119-155$.

Symonds, R.B., Rose, W.I., Bluth, G., Gerlach, T.M., 1994. Volcanic gas studies: methods, results, and applications, In: Carroll, R., Holloway, J.R. (Eds.), Volatiles in magmas. Mineralogical Society of America Reviews in Mineralogy 30, 1-66.

Thurston, P.C., Chivers, K.M., 1990. Secular variation in greenstone sequence development emphasizing Superior Province, Canada. Precambrian Research 46, 21-58. 
Thurston, P.C., Kozhevnikov, V.N., 2000. An Archean quartz arenite-andesite association in the eastern Baltic Shield, Russia: implications for assemblage types and shield history. Precambrian Research 101, 313-340.

Tirsgaard, H., Sønderholm, M., 1997. Lithostratigraphy, sedimentary evolution and sequence stratigraphy of the Upper Proterozoic Lyell Land Group (Eleonore Bay Supergroup) of East and Northeast Greenland. Geological Survey of Greenland Bulletin $178,60 \mathrm{p}$

Trendall, A.F., 2002. The significance of iron-formation in the Precambrian stratigraphic record, In: Altermann, W., Corcoran, P.L. (Eds.), Precambrian Sedimentary Environments: A Modern Approach to Ancient Depositional Systems. International Association of Sedimentologists Special Publication 33, Blackwell, Oxford, pp. 33-66.

Tripati, A., Backman, J., Elderfield, H., Ferretti, P., 2005. Eocene bipolar glaciation associated with global carbon cycle changes. Nature 436, 341-346.

Tucker, M.E., 1982. Precambrian dolomites: petrographic and isotopic evidence that they differ from Phanerozoic dolomites. Geology 10, 7-12.

Tucker, M.E., 1985. Shallow-marine carbonate facies and facies models. Geological Society, London Special Publications 18, 147-169. 
Unrug, R., 1992. Supercontinent cycle and Gondwana assembly: component cratons and timing of suturing events. Journal of Geodynamics 12, 703-714.

Ushikubo, T., Kita, N.T., Cavosie, A.J., Wilde, S.A., Rudnick, R.L., Valley, J.W., 2008. Lithium in Jack Hills zircons: evidence for extensive weathering of Earth's earliest crust. Earth and Planetary Science Letters 272, 666-676.

Vail, P.R., Mitchum, R.M., Jr., Todd, R.G., Widmier, J.M., Thompson, S., III, Sangree, J.B., Bubb, J.N., Hatlelid, W.G., 1977. Seismic stratigraphy and global changes of sealevel, In: Payton, C.E. (Ed.), Seismic stratigraphy - applications to hydrocarbon exploration. American Association of Petroleum Geologists Memoir 26, pp. 49-212.

Van Wagoner, J.C., Mitchum, R.M., Campion, K.M., Rahmanian, V.D., 1990. Siliciclastic sequence stratigraphy in well logs, cores, and outcrops. American Association of Petroleum Geologists Methods in Exploration Series 7, 55p.

Veiga, G.P., Spalletti, L.A., Flint, S., 2002. Aeolian/fluvial interactions and highresolution sequence stratigraphy of a non-marine lowstand wedge: the Avilé Member of the Agrio Formation (Lower Cretaceous), central Neuquén Basin, Argentina. Sedimentology 49, 1001-1019. 
Vlaar, N.J., van Keken, P.E., van den Berg, A.P., 1994. Cooling of the Earth in the Archaean: Consequences of pressure-release melting in a hotter mantle. Earth and Planetary Science Letters 121, 1-18.

Walker, J.C.G., Brimblecombe, P., 1985. Iron and sulfur in the pre-biologic ocean. Precambrian Research 28, 205-222.

Walker, R.G., Plint, A.G., 1992. Wave- and storm-dominated shallow marine systems, In: Walker, R.G., James, N.P. (Eds.), Facies Models, Response to Sea Level Change. Geological Association of Canada, Toronto, pp. 219-238.

Warren, J., 2000. Dolomite: occurrence, evolution and economically important associations. Earth-Science Reviews 52, 1-81.

Washburn, A.L., 1980. Geocryology. A Survey of Periglacial Processes and Environments. Wiley, New York, 406p.

Watanabe, Y., Martini, J.E., Ohmoto, H., 2000. Geochemical evidence for terrestrial ecosystems 2.6 billion years ago. Nature 408, 574-578.

Weiner, S., Dove, P.M., 2011. An Overview of Biomineralization Processes and the Problem of the Vital Effect. Reviews in Mineralogy and Geochemistry 54, 1-29. 
Wilde, S.A., Valley, J.W., Peck, W.H., Graham, C.M., 2001. Evidence from detrital zircons for the existence of continental crust and oceans on the Earth 4.4 Gyr ago. Nature 409, 175-178.

Willbold, M., Elliott, T., Moorbath, S., 2011. The tungsten isotopic composition of the Earth's mantle before the terminal bombardment. Nature 477, 195-198.

Williams, G.E., 1986. Precambrian permafrost horizons as indicators of palaeoclimate. Precambrian Research 32, 233-242.

Williams, G.E., 1991. Milankovitch-band cyclicity in bedded halite deposits contemporaneous with Late Ordovician-Early Silurian glaciation, Canning Basin, Western Australia. Earth and Planetary Science Letters 103, 143-155.

Williams, G.E., 1993. History of the Earth's obliquity. Earth-Science Reviews 34, 1-45.

Williams, G.E., 1994. Resonances of the fluid core for a tidally decelerating Earth: Cause of increased plume activity and tectonothermal reworking events? Earth and Planetary Science Letters 128, 155-167.

Williams, G.E., 2000. Geological constraints on the Precambrian history of Earth's rotation and the Moon's orbit. Reviews of Geophysics 38, 37-59. 
Williams, G.E., 2004. Earth's Precambrian rotation and the evolving lunar orbit: implications of tidal rhythmite data for palaeogeophysics, In: Eriksson, P.G., Altermann, W., Nelson, D.R., Mueller, W.U., Catuneanu, O. (Eds.), The Precambrian Earth: tempos and events. Developments in Precambrian Geology 12, Elsevier, Amsterdam, pp. 473482.

Williams, G.E., 2005. Subglacial meltwater channels and glaciofluvial deposits in the Kimberley Basin, Western Australia: 1.8 Ga low-latitude glaciation coeval with continental assembly. Journal of the Geological Society, London 162, 111-124.

Williams, G.E., 2008. Proterozoic (pre-Ediacaran) glaciation and the high obliquity, lowlatitude ice, strong seasonality (HOLIST) hypothesis: Principles and tests. Earth-Science Reviews 87, 61-93.

Williams, G.E., Schmidt, P.W., 1997. Paleomagnetism of the Paleoproterozoic Gowganda and Lorrain formations, Ontario: low paleolatitude for Huronian glaciation. Earth and Planetary Science Letters 153, 157-169.

Williams, G.E., Tonkin, D.G., 1985. Periglacial structures and palaeoclimatic significance of a late Precambrian block field in the Cattle Grid copper mine, Mount Gunson, South Australia. Australian Journal of Earth Sciences 32, 297-300. 
Williams, G.E., Gostin, V.A., McKirdy, D.M., Preiss, W.V., 2008. The Elatina glaciation, late Cryogenian (Marinoan Epoch), South Australia: sedimentary facies and palaeoenvironments. Precambrian Research 163, 307-331.

Williams, G.E., Gostin, V.A., McKirdy, D.M., Preiss, W.V., Schmidt, P.W., 2011. The Elatina glaciation (late Cryogenian), South Australia. Geological Society of London Memoir 36, 713-721.

Williams, J.G., Boggs, D.H., Turyshev, S.G., Ratcliff, J.T., 2004. Lunar laser ranging science. 14th International Workshop on Laser Ranging, San Fernando, Spain, June 7-11, 2004.

Williams, R.M.E., Rogers, A.D., Chojnacki, M., Boyce, J., Seelos, K.D., Hardgrove, C., Chuang, F., 2011. Evidence for episodic alluvial fan formation in far western Terra Tyrrhena, Mars. Icarus 211, 222-237.

Wyche, S., Nelson, D.R., Riganti, A., 2004. 4350-3130 Ma detrital zircons in the Southern Cross Granite-Greenstone Terrane, Western Australia: implications for the early evolution of the Yilgarn Craton. Australian Journal of Earth Sciences 51, 31-45.

Young, G.M., von Brunn, V., Gold, D.J.C., Minter, W.E.L., 1998. Earth's oldest reported glaciation: Physical and chemical evidence from the Archean Mozaan Group ( 2.9 Ga) of South Africa. Journal of Geology 106, 523-538. 
Young, G.M., Long, D.G.F., Fedo, C.M., Nesbitt, H.W., 2001. Paleoproterozoic Huronian basin: product of a Wilson cycle punctuated by glaciations and a meteorite impact. Sedimentary Geology 141-142, 233-254.

Zahnle, K., Claire, M., Catlin, D., 2006. The loss of mass-independent fractionation in sulfur due to a Palaeoproterozoic collapse of atmospheric methane.Geobiology 4, 271283.

Zentmyer, R.A., Pufahl, P.K., James. N.P., Hiatt, E.E., 2011. Dolomitization on an evaporitic Paleoproterozoic ramp: Widespread synsedimentary dolomite in the Denault Formation, Labrador Trough, Canada. Sedimentary Geology 238, 116-132.

Zhong, S., Zhang, N., Li, Z.-X., Roberts, J.H., 2007. Supercontinent cycles, true polar wander, and very long-wave length mantle convection. Earth and Planetary Science Letters 261, 551-564. 


\section{Figure captions}

Figure 1. The relationship between the duration of a sedimentary unit and its sedimentation rate, showing results from some 25,000 data sets; circled Roman numerals denote modes resulting from the most-used means of calculating sedimentation rates (after Sadler, 1981).

Figure 2. Rates and durations of sedimentary processes. Numerals refer to the Sedimentation Rate Scale (Miall, in press).

Figure 3. Change in the mean Earth-Moon distance with time, as suggested by different average rates of tidal energy dissipation. Curve a: present rate of lunar recession of $3.82 \mathrm{~cm} / \mathrm{yr}$ (Dickey et al., 1994). Curve b: mean rate of lunar recession of $3.16 \mathrm{~cm} / \mathrm{yr}$ since 500 Ma suggested by palaeontological data (Lambeck, 1980). Curve c: mean rate of lunar recession of $2.17 \pm 0.31$ $\mathrm{cm} / \mathrm{yr}$ since the late Cryogenian indicated by the Elatina datum. Curve d: mean rate of lunar recession consistent with the Elatina datum and data for rhythmites from the $2.45 \mathrm{Ga}$ Weeli Wolli Formation. Shaded area shows the error based on the Weeli Wolli datum. Modified from Williams (2000).

Figure 4. Age histograms for the crust and mantle based on $\mathrm{U}-\mathrm{Pb}$ zircon dates and $\mathrm{Re}-\mathrm{O}$ s model ages, respectively (modified after Lee et al., 2011). The U-Pb histogram is modified from Hawkesworth and Kemp (2006). Shaded areas refer to clusters of Re-Os model ages (Carlson et al., 2005). $\mathrm{T}_{\mathrm{MA}}=$ model age.

Figure 5. Factors affecting the temporal abundance of chemical sedimentary rocks. The most significant change in chemical sedimentation occurred during the Great Oxidation Event (orange 
bar). $\mathrm{OC}=$ hypothesized ocean chemistry varying from ferrous (red) to sulphidic (purple) to oxygenated (blue). $\mathrm{P}_{2} \mathrm{O}_{5}=$ phosphorites (yellow). $\mathrm{Fe}=$ iron formations in Precambrian and ironstones in Phanerozoic (red). Ironstones are fundamentally different from iron formations, having accumulated within an oxygenated ocean. Eva $=$ evaporites (green). $\mathrm{CO}_{3}=$ dominant calcium carbonate producers including benthic (B) and planktonic (P) sources. $\mathrm{SiO}_{2}=$ dominant silica sources including sponges and radiolarians (S\&R) and diatoms (D). Atmospheric oxygen proxies used to evaluate minimum (dark blue) and maximum (light blue) oxygen concentrations include volcanic outgassing, detrital pyrite occurrence, the distribution of red beds and palaeosols, and black shales. Modified from compilations by Holland (2006), James et al. (2010), HohmannMarriott and Blankenship (2011), Pufahl and Hiatt (2012).

Figure 6. (A) Polished slab of small domal stromatolites in the Palaeoproterozoic Kona Dolomite, Chocolay Group, Michigan. (B) White dolomite pseudomorphs after gypsum that show the original dolomite formed in association with evaporative conditions, Palaeoproterozoic Kona Dolomite, Michigan. Scale bars are $2 \mathrm{~cm}$ long. Samples provided by Dan Damrow.

Figure 7. The relative abundance of non-siliciclastic sediments through time, showing dolomites to be more abundant than limestones during much of the Proterozoic, when microbial ecosystems dominated the biosphere. Modified after Ronov (1964).

Figure 8. Palaeolatitudinal extent of glacigenic deposits. (1-2) Palaeoproterozoic, (3) Cryogenian, (4) Ediacaran, (5) Cambrian (see text for sources of data). (6) Ice-rafted deposits for the Late Ordovician-Early Silurian, (7) Late Devonian, (8) Early Carboniferous-Late Permian, (9-11) Early Jurassic-Late Cretaceous, and (12) Cenozoic (after Frakes and Francis, 1988). Note change of time-scale at $500 \mathrm{Ma}$. 


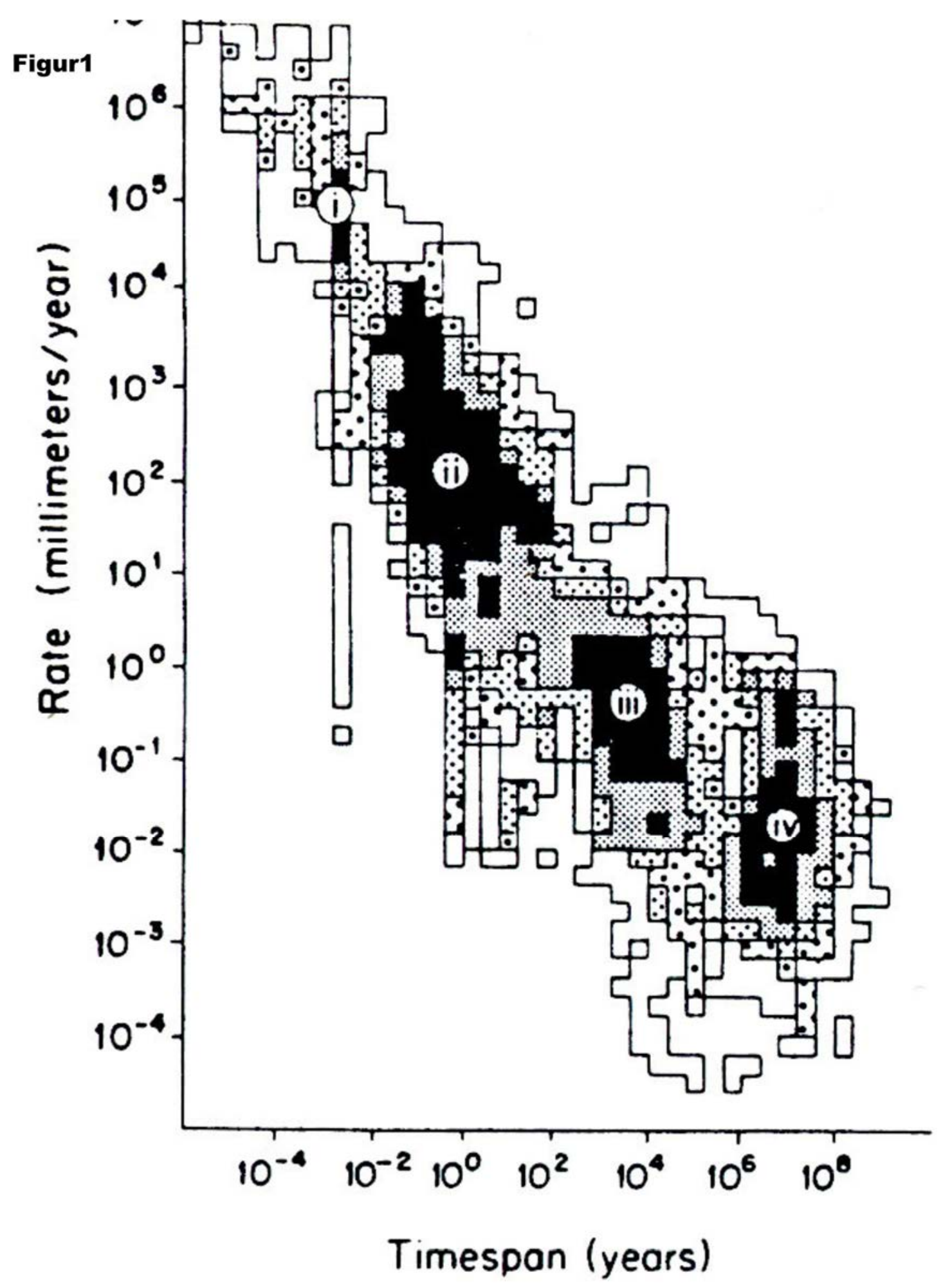

Figure 1 


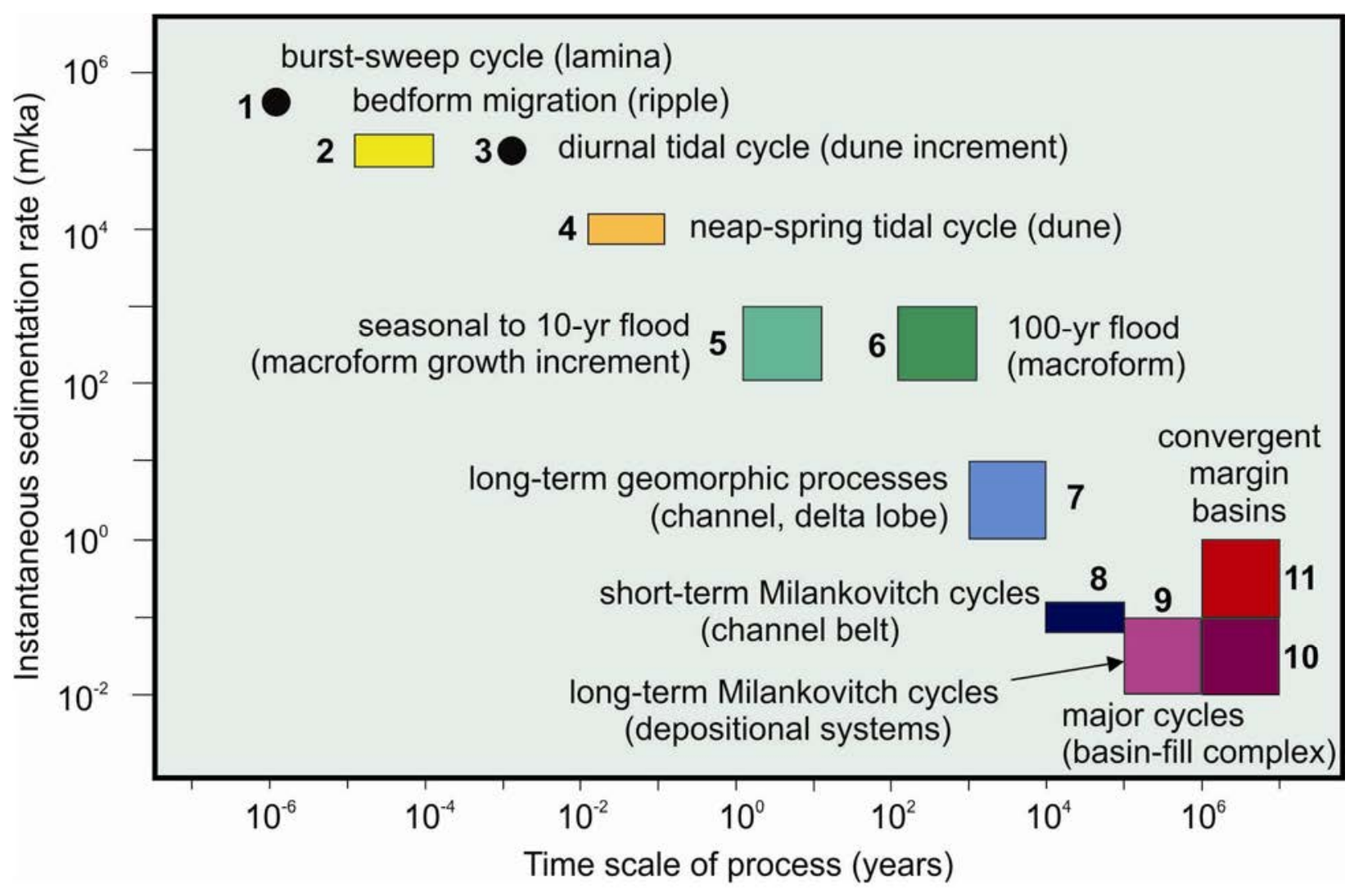

Figure 2 


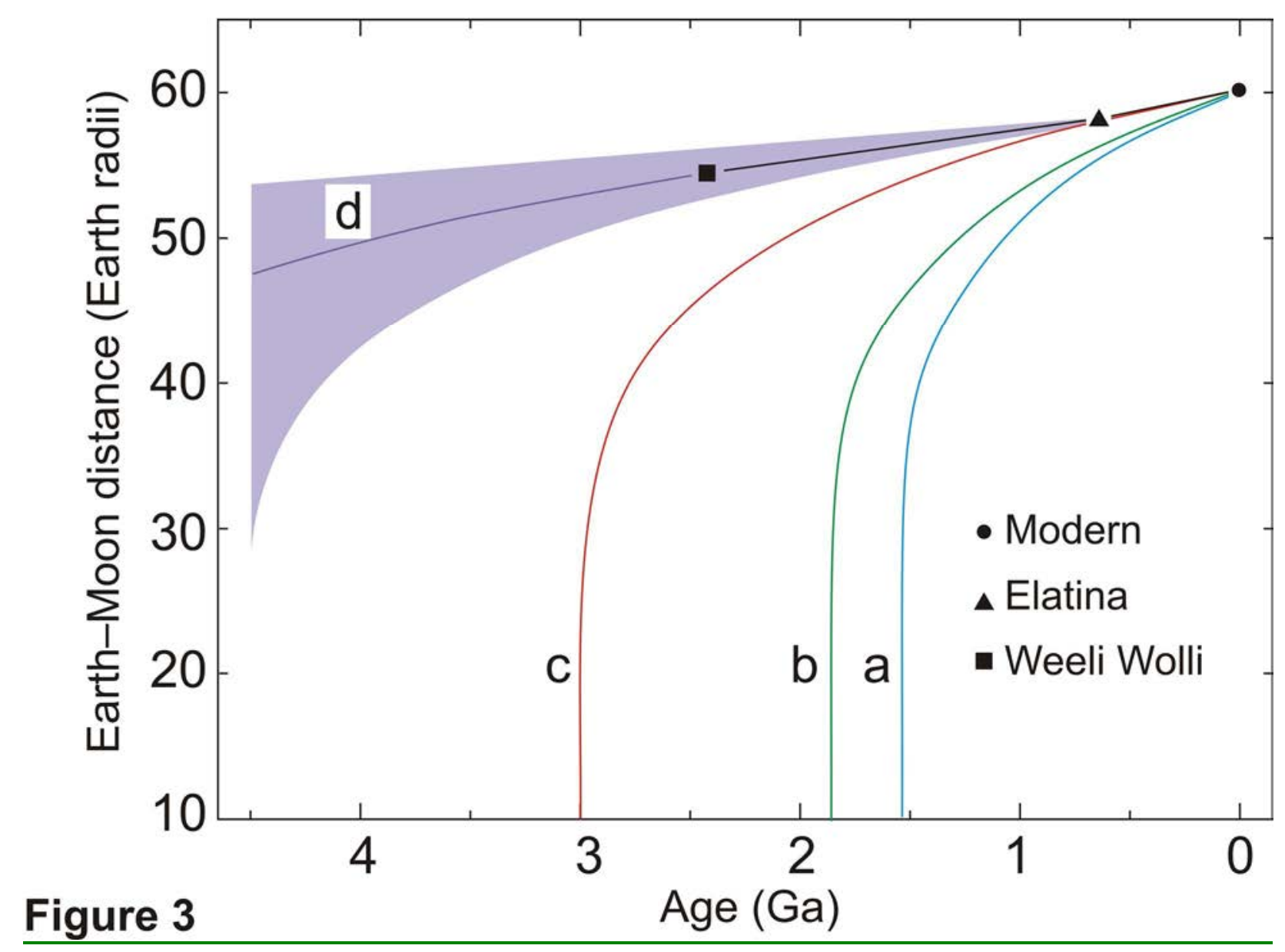




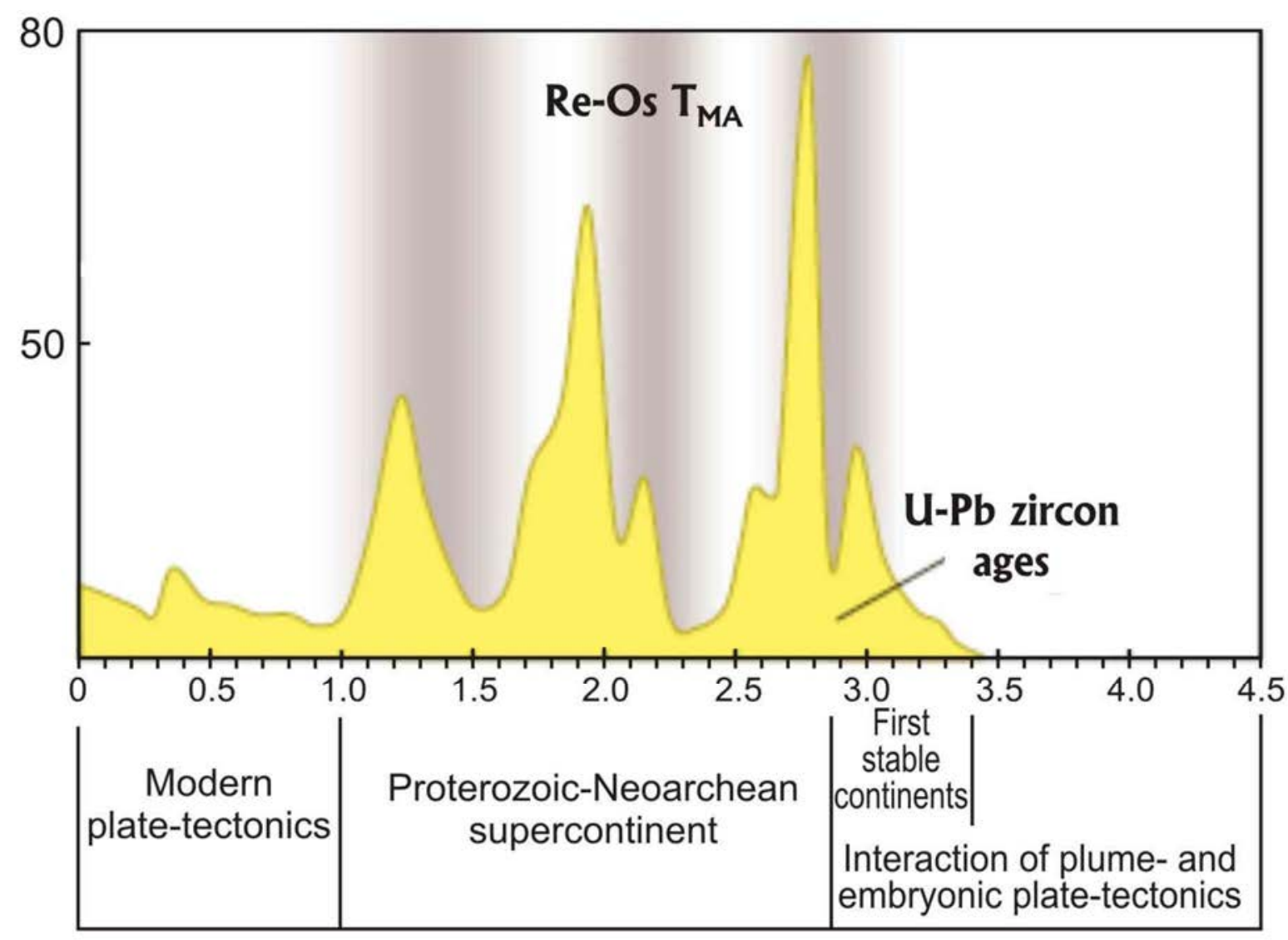

Figure 4 


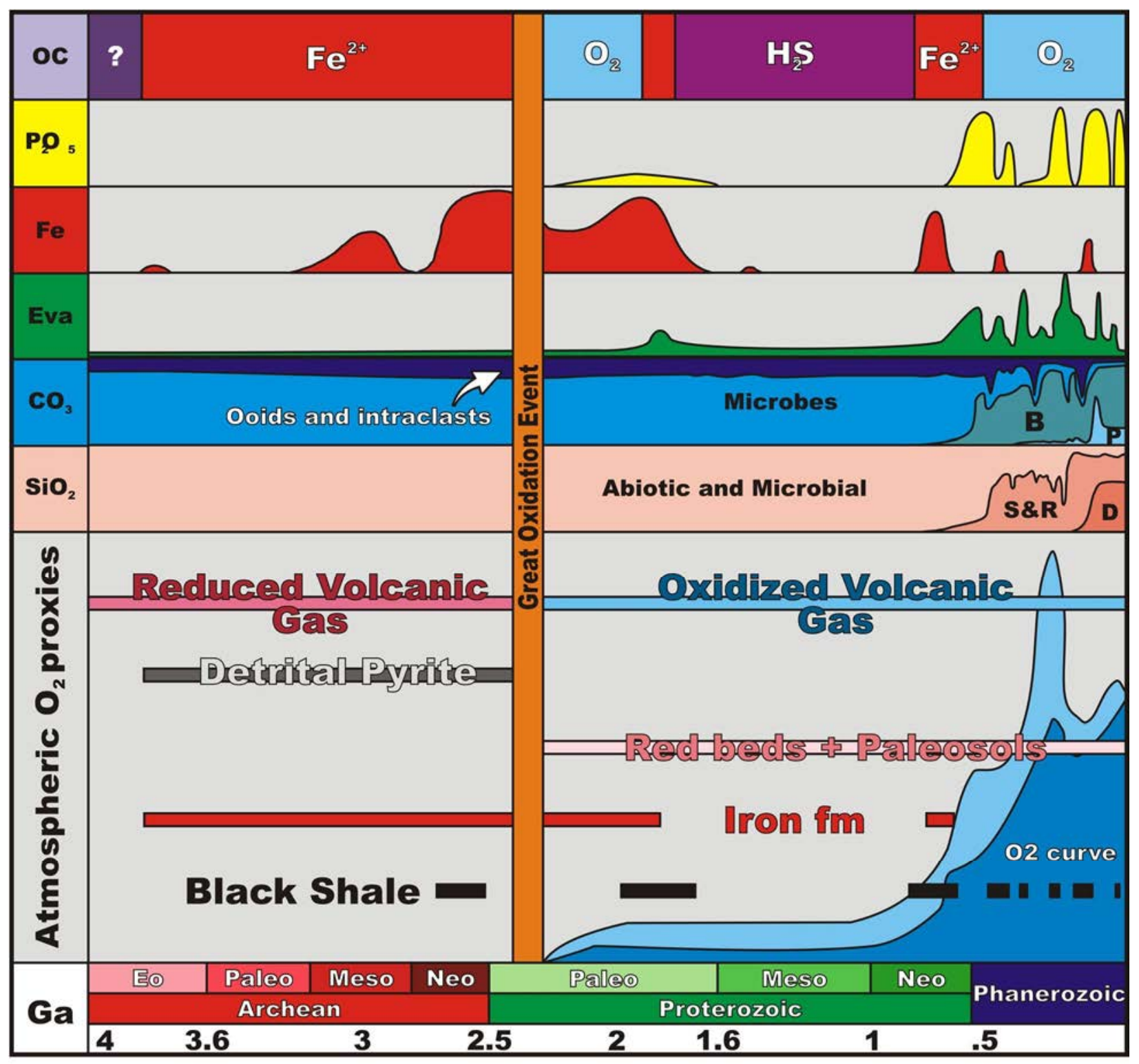

Figure 5 


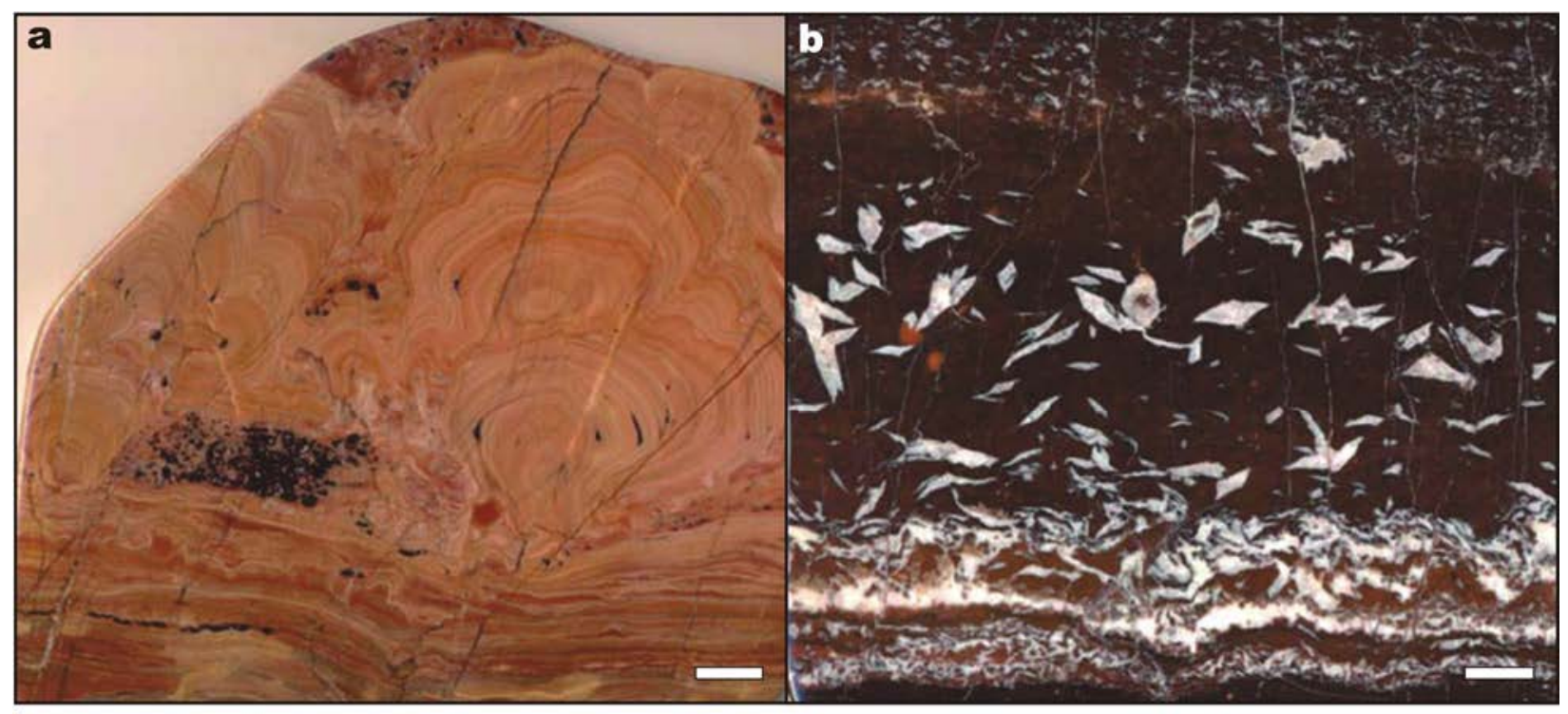

\section{Figure 6}

(Mudrocks, siltstones, sandstones and volcaniclastics etc. make up to $100 \%$ sediments)

\section{Non-siliciclastic sediments through time}
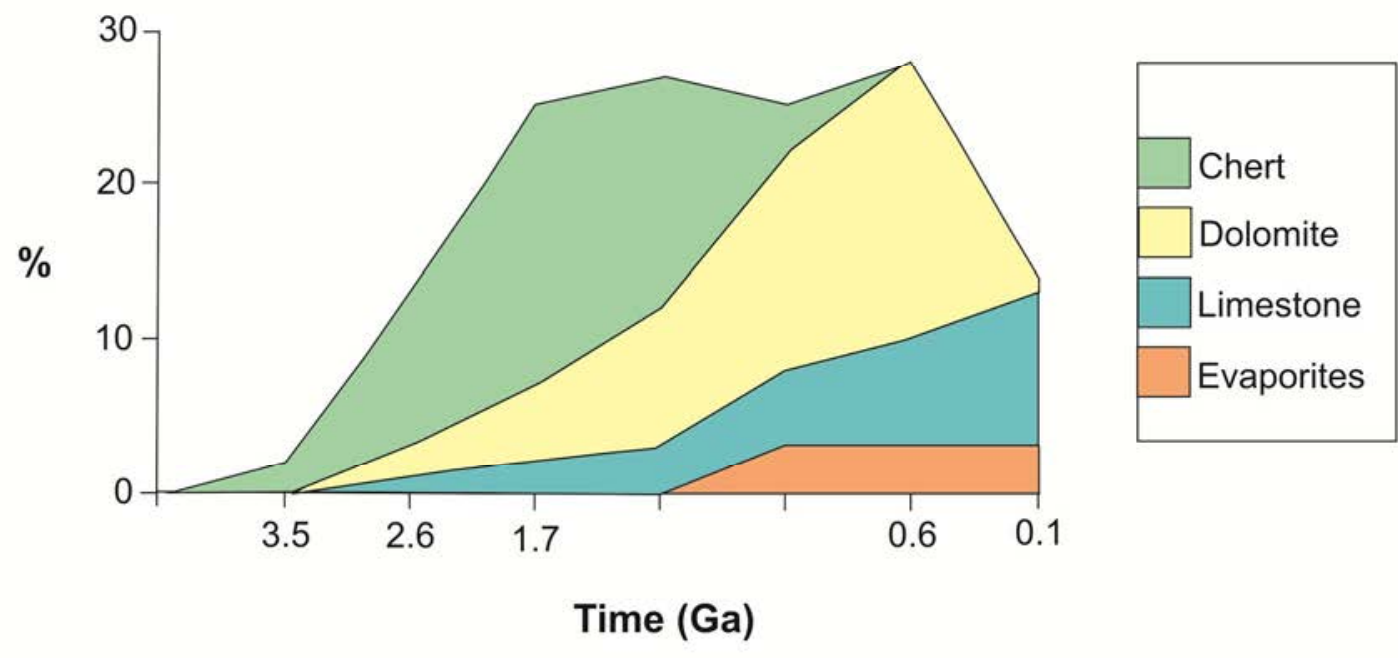

Figure 7 


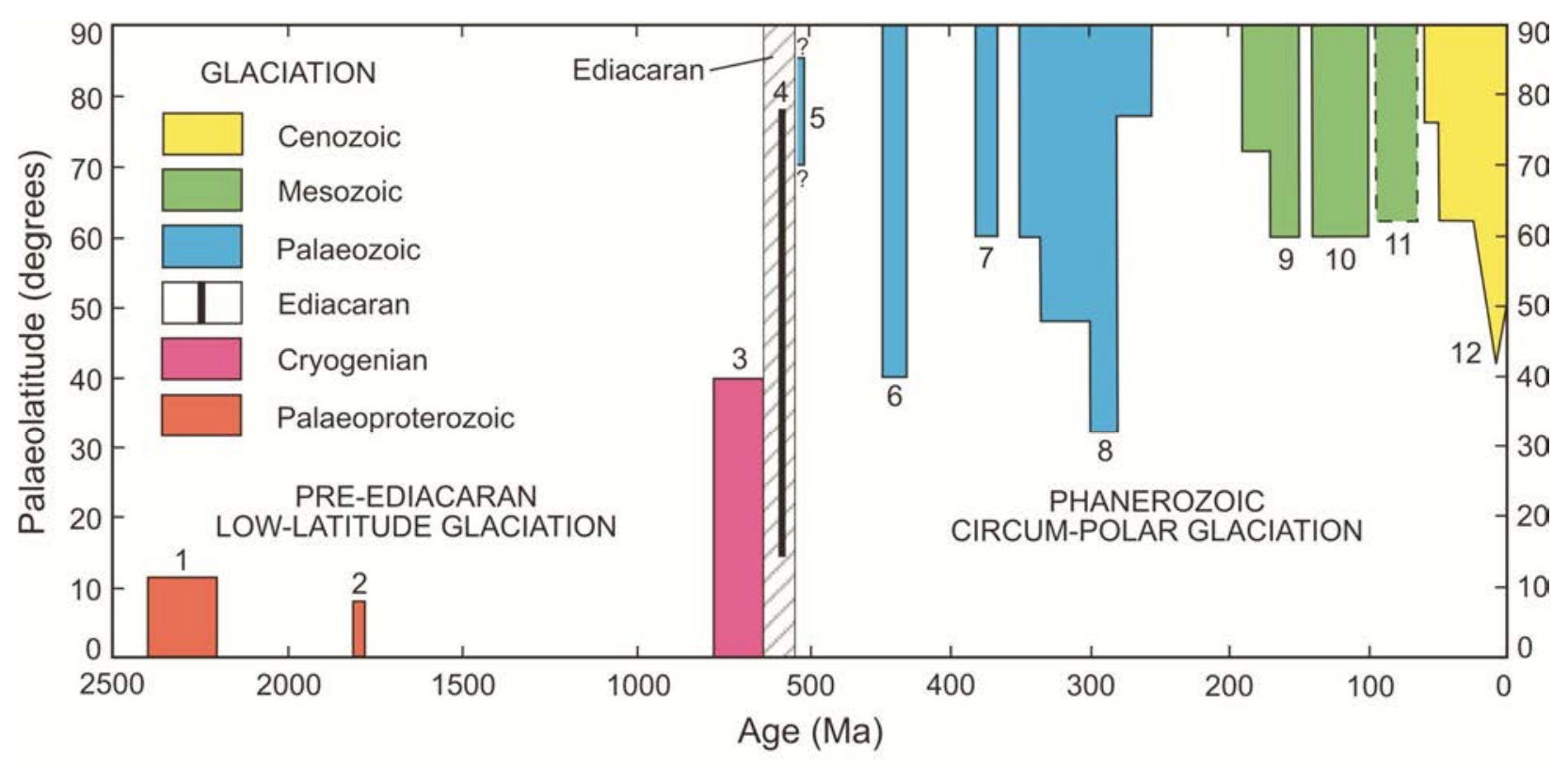

Figure 8 


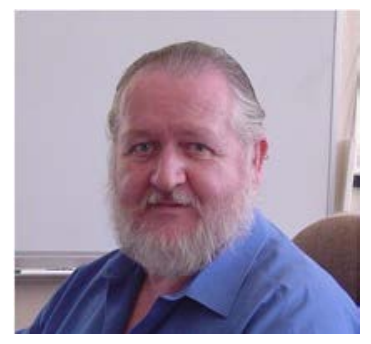

Patrick Eriksson is Professor of Sedimentology and Chair of Geology at the University of Pretoria, South Africa. He holds doctoral degrees from the University of Natal and the Ludwig-Maximilians University in Munich (Dr rer nat habil). His interests are in Precambrian sedimentation systems, microbial mat features in clastic sediments, basin analysis and secular change in the sedimentary record. Eriksson is Vice-President, International Association for Gondwana Research (2012-2014); Continental Scientist Award of the African Union (2009), Fellow of the Royal Society of South Africa (2010).

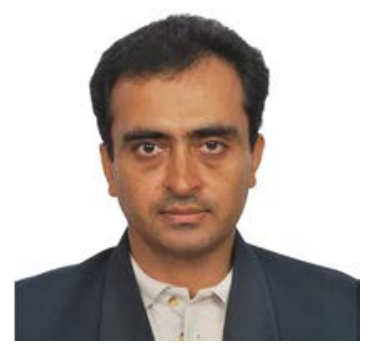

Santanu Banerjee is currently a Professor in the Department of Earth Sciences at the Indian Institute of Technology Bombay, Mumbai, India. He obtained his Ph.D. from Jadavpur University, Kolkata, in 1997. His main research interests are sedimentology, basin analysis, and microbially mediated sedimentation in Proterozoic sedimentary basins. He is also supervising research projects on recent microbial sediments and the sequence stratigraphic context of Phanerozoic glauconites.

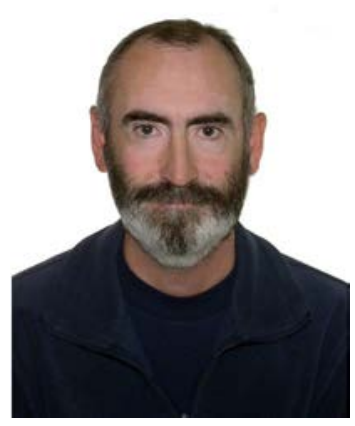

Octavian Catuneanu is Professor in the Department of Earth and Atmospheric Sciences at the University of Alberta, with Ph.D. degrees from the University of Toronto (1996) and the University of Bucharest (1992). He is the recipient of several distinctions in the field of Geology, including the W.W. Hutchison medal of the Geological Association of Canada for exceptional advances in earth science research (2010), and best paper awards from the Geological Society of America (2002) and the Romanian Academy (1994). 
Octavian Catuneanu is the Editor-in-Chief of the Journal of Marine and Petroleum Geology (since 2007), and a member of the editorial board of other journals in North America, Europe and Africa. He is the editor of several books and special issues, and author of numerous publications in the fields of sedimentology, stratigraphy and basin analysis. He is currently involved in several international research programs and as an instructor of sequence stratigraphy and basin analysis for conferences and companies worldwide. His textbook "Principles of Sequence Stratigraphy" (Elsevier, 2006) received a 2007 "Outstanding Academic Title" CHOICE Award from the American Library Association, and remains a best-selling title.

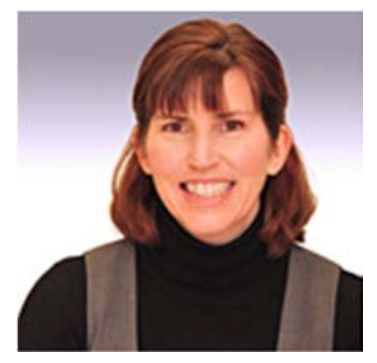

Patricia L. Corcoran is a scientific editor and Associate Professor at the University of Western Ontario, London, Canada. She obtained a Ph.D. at Dalhousie University, Nova Scotia, Canada, and was a Post-Doctoral Fellow at the University of Otago, New Zealand. She investigates Earth's surface and atmospheric processes using the sedimentary rock record, having conducted field studies in the Archaean Slave and Superior geological provinces, the Palaeoproterozoic Transvaal and Huronian supergroups, and the Neoproterozoic Gariep belt.

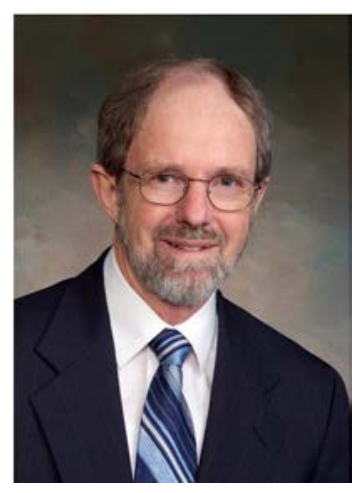

Ken Eriksson completed all of his degrees at the University of the Witwatersrand before moving to the USA in 1978 where he has been on the faculty at Virginia Tech since 1981. His research interests are in interpreting past surface processes on Earth with an emphasis on the Precambrian and Palaeozoic stratigraphic records in Australia, Africa and the USA. 


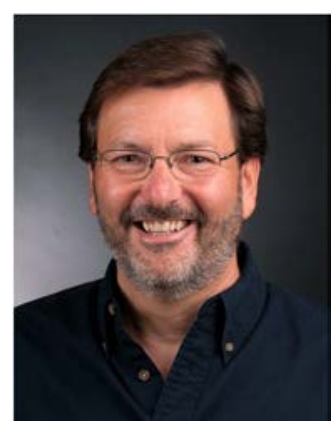

Eric Hiatt, Professor of Geology, University of Wisconsin Oshkosh, U.S.A. teaches sedimentology, sedimentary diagenesis, and oceanography, and does basin analysis research focused primarily on Proterozoic sedimentary systems in Australia, Canada, South America, and the U.S.A. His research includes the origin and evolution of phosphorites and other biochemical sedimentary systems through time. He earned a Ph.D. from the University of Colorado, completed a Postdoctoral Fellowship at Queen's University, worked as an assistant Professor at Queen's, and is an adjunct Professor at Queen's and Acadia universities, Canada.

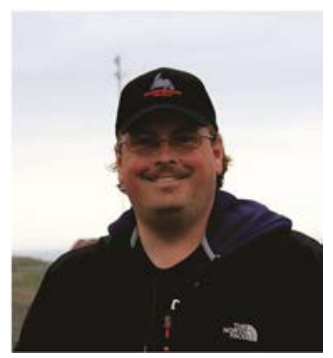

Marc Laflamme received his $\mathrm{PhD}$ at Queen's University in Kingston, Ontario, Canada, and was a postdoctoral fellow at Virginia Tech, Yale University, and the Smithsonian National Museum of Natural History. His research interests lie in the classification and preservation of the Ediacara biota, and in using decay-based experiments to study taphonomic pathways responsible for the preservation of soft-tissue in the fossil record.

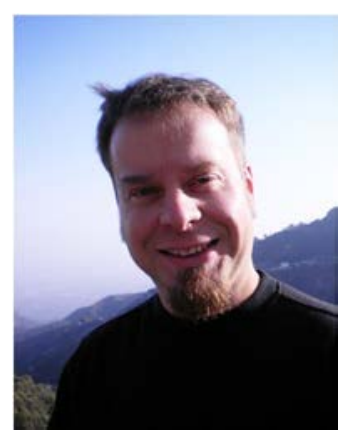

Nils Lenhardt is Lecturer of physical volcanology and economic geology at the Department of Geology, University of Pretoria. He received his MSc (Dipl.-Geol.; 2004) and $\mathrm{PhD}$ (2009) degrees from the Technical University of Darmstadt, Germany. His research, which has, so far, been published in a dozen papers, focuses on Precambrian to recent volcanology of Mexico, South Africa, Sudan, India and Tanzania 


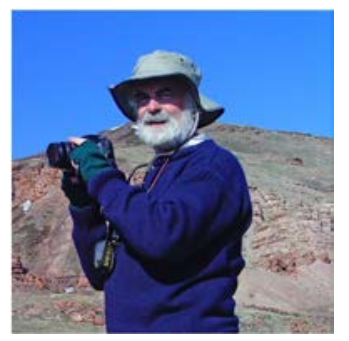

Dr. Darrel Long, B.Sc. (Leicester, UK.), M.Sc. and Ph.D. (Western, ON Canada). Has worked extensively in clastic and carbonate sedimentology in Archaean to Recent basins, concentrating mainly on clastic fluvial facies and architecture. Currently teaching at Laurentian University, Canada.

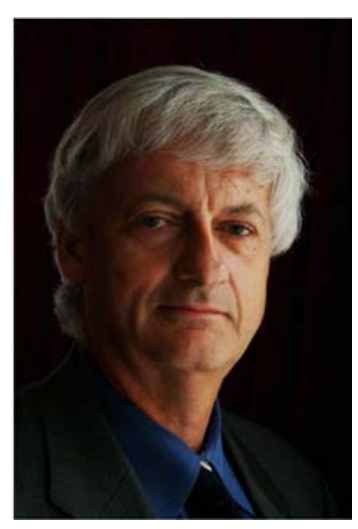

Andrew Miall has been Professor of Geology at the University of Toronto since 1979, specializing in stratigraphy and in the sedimentology and sequence stratigraphy of nonmarine rocks. He was elected a Fellow of the Royal Society of Canada in 1995, and served as President of the Academy of Science 2007-2009.

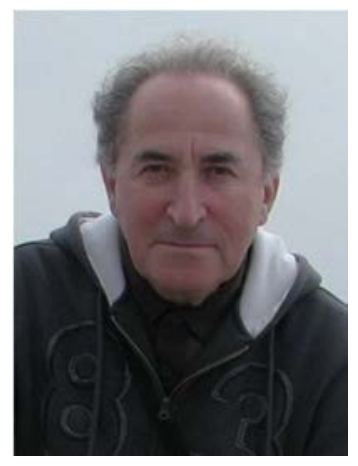

Michael Mints was educated at the Moscow State University in 1961 and graduated with his $\mathrm{PhD}$ (geology-mineralogy) in 1972, followed by a DSc from the Geological Institute of the Russian Academy of Sciences (RAS) in 1993. From 1961 to 1985, he undertook many expeditions for the USSR Ministry of Geology (Geological Survey) as the head of geological parties that dealt with geological mapping and prospecting in Central Kazakhstan, the Okhotsk-Chukotka Palaeovolcanic Belt and the Kola Peninsula. From 
1985 to 1995, he worked in the Institute of the Rare Elements and from 1995 to the present, in the Geological Institute of the RAS where he is head of the Laboratory of Early Precambrian Tectonics; his work has focused on the deep crustal structure of the East European Craton (Fennoscandian Shield and basement of the Russian Platform) and on Early Precambrian tectonics and geodynamics.

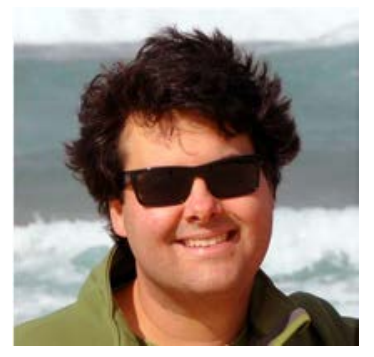

Peir K. Pufahl is an Associate Professor of sedimentology at Acadia University, Canada, where he teaches about oceanography, carbonate rocks, and bioelemental sediments (iron formation, phosphorite, and chert). Peir has a Ph.D. from the University of British Columbia and was a Natural Sciences and Engineering Research Council of Canada Postdoctoral Fellow at Queen's University. His research focuses on understanding the role bioelemental sediments play in Earth evolution. Peir's fieldwork has taken him across North America, the Middle East, coastal Africa, Australia, and Brazil. His investigations of phosphorites and giant iron formations have provided new insight into the cycling of bioessential elements on the early Earth.

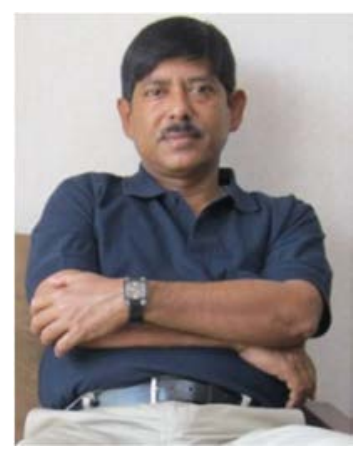

Subir Sarkar is currently Associate Professor in the Department of Geological Sciences, Jadavpur University, India. He obtained his Ph.D. from Jadavpur University in 1990. Dr. Sarkar has worked in different sedimentary basins of India and his scientific interests are in the areas of sequence stratigraphy, biosedimentology, and basin analysis. With a special interest in the record of early life, he is currently studying the influence of microbial mats on Precambrian sedimentation. 


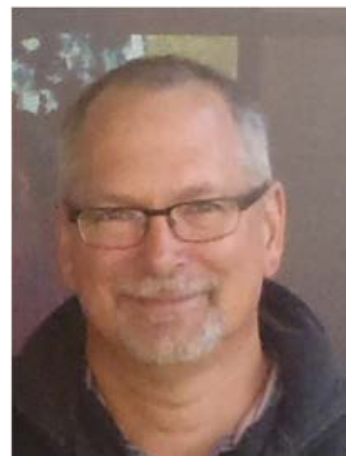

Edward L. Simpson is a Professor and Chairperson at Kutztown University of Pennsylvania. He received his B.S. in Secondary Education from Kutztown State College (1980), a M.S. in Geology from the University of Nebraska (1983) and a Ph.D. in Geology from Virginia Tech (1987). His research involves Precambrian desert systems, Carboniferous and Triassic sedimentation and ichnology of eastern Pennsylvania, and the effects of syntectonic deformation on fluvial styles in southern Utah.

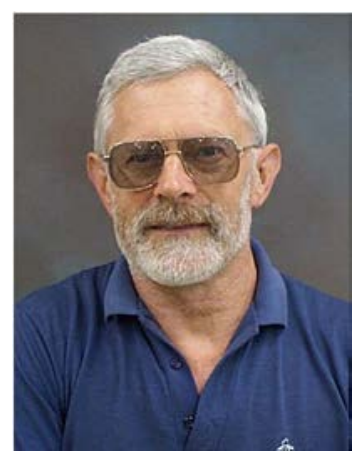

George Williams holds an MSc from the University of Melbourne and a $\mathrm{PhD}$ from the Sedimentology Research Laboratory, University of Reading. His career has been divided between industry and research based at the University of Adelaide, mostly on Precambrian sedimentology, palaeoclimatology, palaeomagnetism and meteoritics. He was awarded a DSc by the University of Reading in 1998 and elected a Fellow of the Australian Academy of Science in 2011. 